\title{
INFLUÊNCIA DA MUDANÇA DO USO DA TERRA SOBRE A MATÉRIA ORGÂNICA DO SOLO NO MUNICÍPIO DE SÃO PEDRO-SP
}

\author{
DINAILSON CORRÊA DE CAMPOS \\ Biólogo
}

Orientador: Prof. Dr. CARLOS CLEMENTE CERRI

Dissertação apresentada à Escola Superior de Agricultura "Luiz de Queiroz", Universidade de São Paulo, para obtenção do título de Mestre em Agronomia, Área de Concentração: Microbiologia Agrícola.

\section{PIRACICABA}

Estado de São Paulo - Brasil

Fevereiro - 1998 
Dados Internacionais de Catalogação na Publicação (CIP) DIVISĀO DE BIBLIOTECA E DOCUMENTAÇĀO - Campus "Luiz de Queiroz"/USP

Campos, Dinailson Corrèa de Influência da mudança do uso da terra sobre a matéria orgânica do solo no municipio de São Pedro-SP / Dinailson Corrêa de Campos. - - Piracicaba , 1998. 83 p. : il.

Dissertação (mestrado) - Escola Superior de Agricultura Luiz de Queiroz, 1998. Bibliografia.

1. Biomassa microbiana do solo 2. Cana-de-açucar 3. Eucalipto 4. Matéria orgânica do solo 5. Relação solı pastagem Rio Piracicaba (Bacia) 7. Uso da terra I. Título 
INFLUÊNCIA DA MUDANÇA DO USO DA TERRA SOBRE A MATÉRIA ORGÂNICA DO SOLO NO MUNICÍPIO DE SÃO PEDRO-SP

\author{
DINAILSON CORRÊA DE CAMPOS
}

Aprovado em: 23.04.1998

Comissão julgadora:

Prof. Dr. Carlos Clemente Cerri

CENA/USP

Prof. Dra. Brigitte Josefine Feigel

CENA/USP

Prof. Dra. Regina Teresa Rosim Monteiro

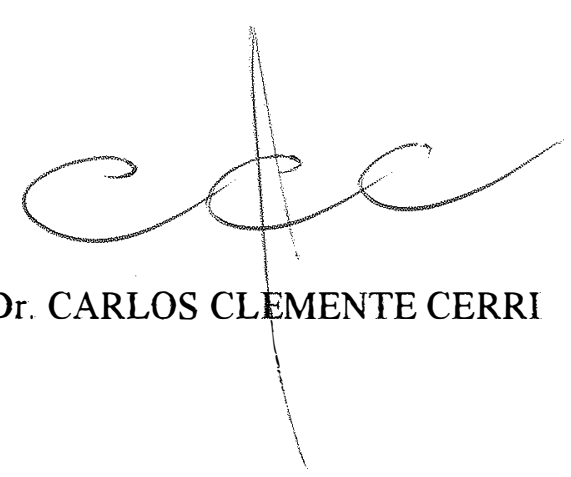




\section{OFEREÇO ESTE TRABALHO}

À Joceli, por tudo que ela representa como fonte de energia durante a caminhada e porto seguro ao final de cada dia

\section{DEDICO ESTE TRABALHO}

Aos meus filhos Laura e Augusto motivo maior de todo o meu viver

Aos meus pais João e Lusia, por terem me dado o bem maior, a vida, e por terem me propiciado a educação que me permitiu chegar até aqui

Ao meu irmão Dinael, em quem sempre me espelhei.

Às minhas irmãs Dionéia e Diovana, fonte de alegria e carinho

“...uma coisa é você achar que está no caminho certo, outra é achar que seu caminho é o único..."

Paulo Coelho 


\section{AGRADECIMENTOS}

Ao término de mais uma etapa da minha vida, gostaria de expressar os meus sinceros agradecimentos a todos que colaboraram para que o presente estudo fosse realizado:

- Ao CPG em Microbiologia Agrícola da Escola Superior de Agricultura "Luiz de Queiroz"- ESALQ/USP, pela possibilidade de realizar o curso de Pós-Graduação e pelos ensinamentos recebidos.

- Ao Professor Dr. Carlos Clemente Cerri, pela orientação, amizade e incentivo na realização e condução deste trabalho.

- Ao Centro de Energia Nuclear na Agricultura(CENA/USP) pela oportunidade da realização deste trabalho.

- Às Professoras Dra. Brigitte Feigel e Dra. Marisa Piccolo do Laboratório de Biogeoquímica do Solo (CENA/USP), pela amizade, apoio e ensinamentos recebidos.

- Aos amigos da seção de Biogeoquímica do Solo, José Roberto Martins, Sandra Nicolete, Mara Casarin, Dacir Ribeiro e aos estagiários: Leandro,Alexandre, Elaine, Roberta, Márcia, Andréia e Juliana, pela amizade e o apoio técnico recebido sem os quais não teria sido possível a realização deste trabalho.

- Aos amigos de pós-graduação Martial Bernoux, Paulo Maurício, Marciano Brito, Jener Moraes, Solismar Venske, Maria da Conceição Carvalho, Silvana P. Fernandes, João Carlos Sá, cada qual contribuindo com sua amizade e experiência.

- Ao amigo Luiz Humberto Gomes pela amizade e incentivo em mais esta jornada.

- Ao CNPq pela concessão da bolsa de estudos.

- Aos proprietários das áreas estudadas: Hélio Zanatta (Sítio São José), Domingos Silloto (Sítio Bom Retiro), Indústria de Papel Gordinho Braune (Fazenda La Rossana) e aos proprietários do Sítio Antonio Antonelli.

- A todos que, direta ou indiretamente, prestaram o seu apoio e incentivo a realização desse trabalho. 


\section{SUMÁRIO}

Página

LISTA DAS FIGURAS ................................... viii

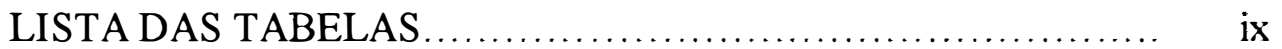

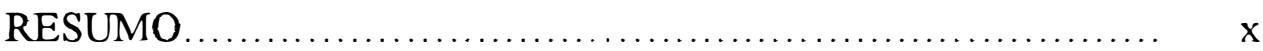

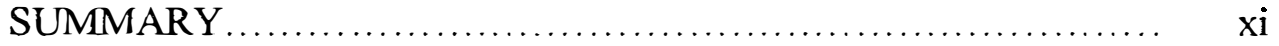

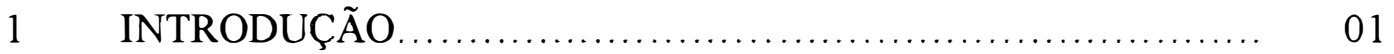

2 REVISÃO DE LITERATURA ................................ 04

2.1 A intensificação da agricultura e as modificações no ambiente........ 04

2.2 Alterações nas propriedades do solo em consequência do cultivo e do manejo..................................................... 05

2.2.1 Alterações nas propriedades químicas do solo..................... 06

2.2.2 Alterações nas propriedades físicas.............................. 07

2.2.2.1 Considerações sobre o método de avaliação da estabilidade dos agregados

2.3 O papel da matéria orgânica na dinâmica do solo e as mudanças devido ao uso do solo ..................................... 09

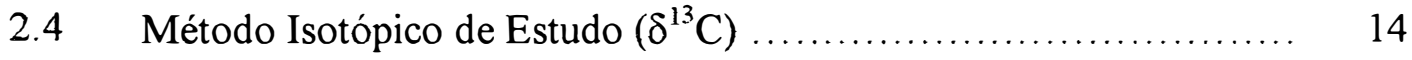

2.5 A biomassa microbiana como indicador das alterações nas propriedades do solo.......................................... 16

3 MATERIAL E MÉTODOS ...................................... 18

$3.1 \quad$ Caracterização da região estudada ................................ 18

3.1.1 Localização da área de estudos.................................. 18

3.1.2 Clima, Solo e Relevo......................................... 19

$3.1 .3 \quad$ O uso da terra na região .................................... 21

3.2 Seleção e descrição das áreas de estudos.......................... 21

3.2.1 Mata Nativa............................................... 22

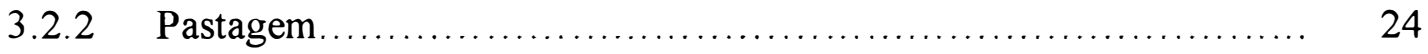

$3.2 .3 \quad$ Cana-de-açúcar............................................ 24 


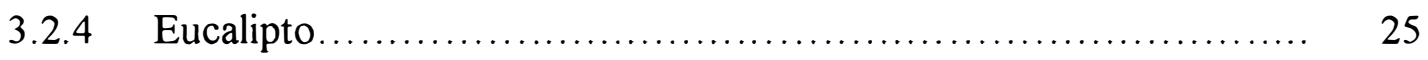

3.3 Amostragem .............................................. 25

3.3.1 Amostragem de solo ........................................ 25

3.3.2 Amostragem de gases ........................................ 26

$3.4 \quad$ Preparação das amostras....................................... 28

3.5 Análises químicas do solo ..................................... 29

3.6 Análises físicas do solo ...................................... 30

3.7 Determinação do estoque de carbono total......................... 31

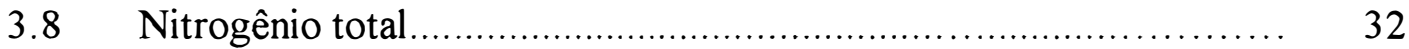

3.9 Fracionamento da matéria orgânica ............................. 32

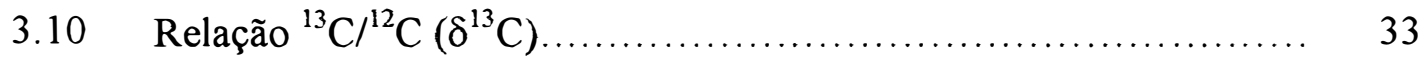

3.11 Estimativa da biomassa microbiana $\mathrm{C}$ pelo método da FumigaçãoExtração..................................................... 34

3.12 Estimativa da biomassa microbiana $\mathrm{N}$ pelo método da FumigaçãoExtração ...................................................... 34

$4 \quad$ RESULTADOS E DISCUSSÃO ............................................... 36

4.1 Características fisicas e fisico-químicas dos solos 36

4.1.1 Características granulométricas................................ 36

$4.1 .2 \quad$ Densidade ................................................. 38

4.1.3 Estabilidade dos agregados................................... 40

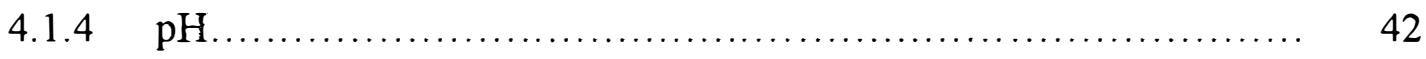

4.2 Características químicas ..................................... 44

4.2.1 Acidez trocável............................................... 44

4.2.2 Soma de bases.............................................. 45

4.3 Mudança na quantidade e qualidade da matéria orgânica do solo.... 46

4.3.1 Porcentagem de carbono........................................ 46

4.3.2 Conteúdo de carbono do solo. ............................................. 49

4.3.3 Porcentagem de nitrogênio ..................................... 52

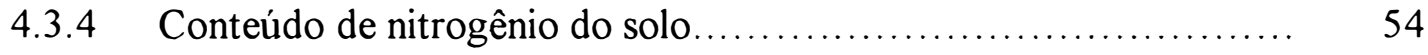

4.3.5 Relação C/N ................................................ 55 
4.4 Dinâmica da matéria orgânica do solo devido às alterações do uso da terra 56

4.5 Estimativa da biomassa microbiana do solo sob diferentes culturas 61

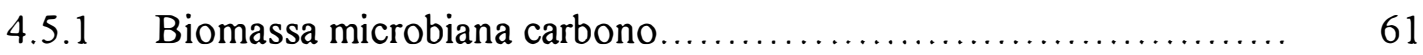

4.5.2 Biomassa microbiana nitrogênio.................................. 64

4.5.3 Relação entre C total, N total e biomassa microbiana................ 66

4.6 Emissão de Gases.......................................... 68

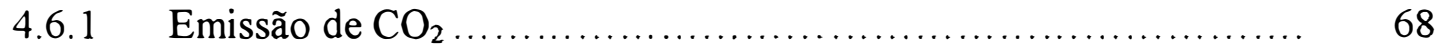

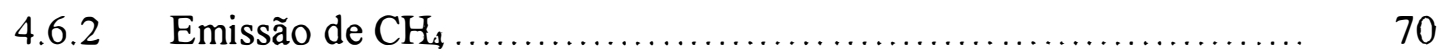

$4.7 \quad$ Fracionamento Químico................................... 70

$4.8 \quad$ Fracionamento Físico .................................. 72

4.9 Conseqüências da alteração do uso da terra...................... 73

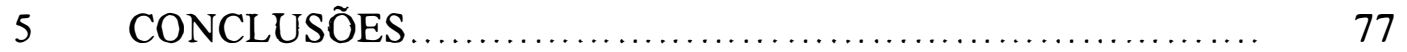

6 REFERÊNCIAS BIBLIOGRÁFICAS ........................... 78 


\section{LISTA DAS FIGURAS}

Página

1 Localização da Bacia do Rio Piracicaba no Estado de São Paulo......... 18

2 Localização da área de estudos na Bacia do Rio Piracicaba............... 19

3 Solos do Município de São Pedro, com as áreas de estudos.............. 20

4 Mapa de ocupação da área da bacia do Rio Piracicaba.................. 21

5 Representação gráfica da seqüência da implantação das culturas( Mata, Pastagem, Eucalipto e Cana-de-açúcar................................ 23

6 Representação esquemática da amostragem............................ 26

7a Esquema das câmaras para coleta de gás............................ 27

7b Foto da câmara de coleta de gás durante coleta numa área de pastagem . 27

8 Esquema do método da fumigação-extração para a determinação de biomassa microbiana ............................................ 35

9 Distribuição granulométrica dos solos sob as culturas estudadas ......... 38

10 Carbono estocado nas diversas profundidades do solo .................. 50

11 Nitrogênio estocado nas diversas profundidades ....................... 55

12 Relação $\mathrm{C} / \mathrm{N}$ ao longo do perfil nas quatro culturas estudadas ............ 56

13 Porcentagem de carbono derivado da cultura e remanescente da mata ... 60

14 Distribuição da biomassa microbiana $(\mathrm{C}$ e $\mathrm{N})$ ao longo do solo nas áreas

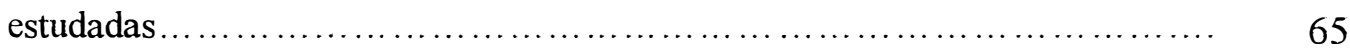

15 Distribuição relativa das substâncias húmicas nas quatro situações estudadas ..................................................... 71

16 Distribuição relativa do carbono nas frações granulométricas............. 73 


\section{LISTA DAS TABELAS}

Página

1 Porcentual de ocupação da área agrícola - Bacia do Rio Piracicaba...... 06

2 Características fisicas e físico-químicas do solo sob mata natural e cultivados.. $\quad 37$

3 Diâmetro médio ponderado avaliado em água, álcool e benzeno, sob efeito das diversas coberturas do solo........................... 41

4 Conteúdo de Carbono orgânico e Nitrogênio total do solo sob mata e

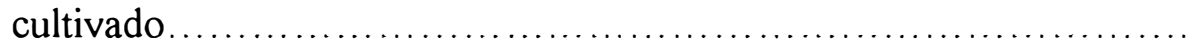

5 Conteúdo de Carbono total, carbono derivado da mata e carbono derivado da cultura nas quatro situações estudadas. ....................

6 Estimativa da biomassa microbiana $\mathrm{C}$ e $\mathrm{N}$ pelo método da extração e porcentagem de carbono e nitrogênio sob a forma de biomassa

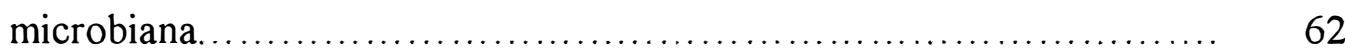

7 Emissão dos gases $\mathrm{CO}_{2}$ e $\mathrm{CH}_{4}$ do solo sob mata nativa e culturas........ 


\title{
INFLUÊNCIA DA MUDANÇA DO USO DA TERRA SOBRE A MATÉRIA ORGÂNICA DO SOLO NO MUNICÍPIO DE SÃO PEDRO-SP
}

\author{
Autor: DINAILSON CORRÊA DE CAMPOS \\ Orientador: Prof. Dr. CARLOS CLEMENTE CERRI
}

\section{RESUMO}

Esta pesquisa teve como objetivo interpretar as variações das propriedades físicas, químicas e biológicas de um solo do município de São Pedro-SP decorrentes da transformação de áreas de floresta latifoliada semidecídua em áreas com pastagem e, posteriormente partes desta convertida em cultivo com eucalipto e cana-de-açúcar.

Amostras de um mesmo tipo de solo(areia quartzosa), foram analisadas quanto ao estoque de carbono e nitrogênio total, $\mathrm{pH}$, granulometria, densidade, estabilidade estrutural, biomassa microbiana $\mathrm{C}$ e $\mathrm{N}$ pelo método da extração, evolução de $\mathrm{CO}_{2}, \delta{ }^{13} \mathrm{C}$ e o fracionamento químico e fisico.

Observou-se que o conteúdo da matéria orgânica do solo, expresso em toneladas de carbono por hectare, diminui com a introdução da pastagem em cerca de sessenta porcento, baixando o estoque total de $109,6 \mathrm{t} \mathrm{ha}^{-1}$ para $39,4 \mathrm{t} \mathrm{ha}^{-1}$. Deste estoque, aproximadamente quarenta porcento é remanescente da mata.

Quando parte da área com pastagem é convertida para cana-de-açúcar, o estoque diminui para setenta porcento do original, com cerca de $33,4 \mathrm{t} \mathrm{ha}^{-1}$. A influência do carbono remanescente da mata nativa é maior nesta área, representando cerca de setenta porcento do carbono do solo. Com a conversão de parte da pastagem para a cultura do eucalipto ocorre recuperação do estoque de carbono, com um aumento da ordem de cinqüenta porcento em relação ao encontrado na pastagem, alcançando um estoque de $59,6 \mathrm{t} \mathrm{ha}^{-1}$.

$\mathrm{O}$ estoque de nitrogênio diminui de $2,8 \mathrm{t} \mathrm{ha}^{-1}$ na área com mata nativa para $1,7 \mathrm{t}$ $\mathrm{ha}^{-1}$ na área com pastagem e diminui ainda mais na área com cana-de-açúcar que mesmo recebendó um aporte anual de nitrogênio, apresenta o menor estoque com cerca de $1,2 \mathrm{t}$ $\mathrm{ha}^{-1}$. Na área com eucalipto o estoque é próximo ao encontrada na área com pastagem com um estoque de $1,6 \mathrm{t} \mathrm{ha}^{-1}$.

A biomassa microbiana concentra-se nas camadas superficiais do solo e mostra-se maior na área com mata nativa com uma estimativa da ordem de $289,0 \mu \mathrm{g} \mathrm{C} \mathrm{g}^{-1}$, seguida pela área com pastagem com $190,4 \mu \mathrm{g} \mathrm{C} \mathrm{g}^{-1}$, cana-de-açúcar $154,8 \mu \mathrm{g} \mathrm{C} \mathrm{g}^{-1}$ e eucalipto $45,2 \mu \mathrm{g} \mathrm{C} \mathrm{g}^{-1}$. A evolução de $\mathrm{CO}_{2}$ foi maior na área com pastagem, seguida pela mata nativa, cana-de-açúcar e eucalipto.

A agregação do solo é afetada diminuindo nas áreas com pastagem e principalmente cana-de-açúcar. $\mathrm{Na}$ área com eucalipto a estabilidade dos agregados se aproxima daquela encontrada na área com mata nativa. A densidade do solo nas áreas com pastagem e cana-de-açúcar indicam um processo de compactação do solo, enquanto que na área com eucalipto a densidade é próxima àquela encontrada para a área com mata. 


\title{
INFLUENCIE OF LAND-USE CHANGE ON SOIL ORGANIC MATTER IN SÃO PEDRO-SP
}

\author{
Author: DINAILSON CORREA DE CAMPOS \\ Adviser: Prof. Dr. CARLOS CLEMENTE CERRI
}

\section{SUMMARY}

The objective of this study was to analyze the changes in physical, chemical and biological properties of sandy soils, located at São Pedro-SP, after the conversion of a semi-deciduous broad-leaved forest into pasture, followed, or not, by eucalyptus or sugarcane implantation.

Analyses consist in determinations of carbon, total nitrogen, granulometric composition, common chemical determinations, bulk density, structural stability, $\mathrm{C}$ and $\mathrm{N}$ microbial biomass using the extraction method, $\mathrm{CO}_{2}$ evolution, $\delta^{13} \mathrm{C}$ and determinations of the chemical and physical fractions.

It was observed that the soil organic matter content, reported in tons of $\mathrm{C}$ per hectare, decreases by $60 \%$ after 60 years of pasture installation decreasing of $109,6 \mathrm{t} \mathrm{ha}^{-1}$ to $39,4 \mathrm{tha}^{-1}$, and around $45 \%$ of the total is remaining $\mathrm{C}$ from the forest. In the area where the pasture was converted into sugar-cane, the carbon in stock represents only $30 \%$ of the original amount, with a stock of $33,4 \mathrm{t} \mathrm{ha}^{-1}$, but $70 \%$ of the total is $\mathrm{C}$ remaining from the forest. When part of the pasture is converted into eucalyptus, the carbon in stock is partially recovered after 12 years. The increase reach $50 \%$ in relation to $\mathrm{C}$ in stock under the pasture with a stock of $59,6 \mathrm{t} \mathrm{ha}^{-1}$.

The nitrogen in stock decreases of $2,8 \mathrm{t} \mathrm{ha}^{-1}$ in forest to $1,7 \mathrm{t} \mathrm{ha}^{-1}$ in pasture area, in the sugar-cane area where, even with an annual nitrogen input, the stock is the lowest with $1,2 \mathrm{tha}^{-1}$ storage. In the eucalyptus area the stock is $1,6 \mathrm{t} \mathrm{ha}^{-1}$.

The microbial biomass is concentrated in the upper layers, and is larger in the native forest area with $289,0 \mu \mathrm{g} \mathrm{C} \mathrm{g}^{-1}$, and then in the pasture $190,4 \mu \mathrm{g} \mathrm{C} \mathrm{g}^{-1}$, sugar-cane $154,8 \mu \mathrm{g} \mathrm{C} \mathrm{g}^{-1}$ and eucalyptus area $45,2 \mu \mathrm{g} \mathrm{C} \mathrm{g}^{-1}$. The $\mathrm{CO}_{2}$ evolution is more important in the soil under pasture, then under forest, sugar-cane and eucalyptus.

Soil aggregation is affected. It decrease in the pasture area and with sugar-cane. In the eucalyptus area, it seems that the stability of the aggregates tends to approach the original one encountered under native forest. Changes in soil bulk density evidence compactation processes in the areas of pasture and sugar-cane, and on the contrary in the eucalyptus area where the soil bulk density is similar to that under forest. 


\section{INTRODUÇÃO}

O crescimento populacional, verificado sobretudo nas regiões intratropicais do globo, tem exigido um intenso uso do solo com o objetivo de aumentar a produção de alimentos. Essa atividade além de ocasionar a expansão da fronteira agrícola, tem causado os inevitáveis e indesejáveis desmatamentos, os quais podem provocar a degradação dos solos e alterações do meio ambiente.

No Brasil, o crescimento das fronteiras agrícolas acentuou-se a partir da década de 70 , com a liberação de créditos agrícolas, devido a uma política de desenvolvimento implantada, a qual possibilitou, também, uma intensa industrialização, urbanização e modernização da agricultura.

No estado de São Paulo, mais especificamente nas cidades economicamente mais importantes, ocorreu crescimento de culturas exportáveis (laranja e soja) e da canade-açúcar principalmente, devido ao PROÁLCOOL, que visava uma outra fonte energética como combustível. Houve aumento de produtividade em culturas como arroz, cebola, batata, tomate e frutas. E na pecuária aumentaram as áreas com pastagem cultivada, para criação de gado para corte e leite. Na região de Piracicaba, foram concentrados investimentos na produção de cana-de-açúcar, bem como ocorreu aumento nas áreas com pastagem cultivada.

A substituição da vegetação nativa por culturas, produz impactos na qualidade ambiental. Dependendo da cultura introduzida, a agricultura convencional provoca alterações nas propriedades do solo, como redução da diversidade biológica e da atividade da meso e microfauna, perda da estrutura do solo ocasionando compactação e erosão, e ainda, mudanças no estoque de nutrientes. Na maioria dos casos a 
produtividade decresce após certo tempo ( 2 a 3 anos) de cultivo, ficando sua manutenção dependente da ciclagem dos nutrientes contidos na liteira.

O principal aporte de nutrientes para o solo se dá através da decomposição da matéria orgânica e a fertilidade tende a ser recuperada com a utilização de insumos (calcário e adubo principalmente), que tornam o custo da produção agrícola uma prática dispendiosa e em muitos casos inviável economicamente.

Um dos indicativos das características nutricionais de um solo é a quantidade de matéria orgânica, que geralmente é expressa pelo seu conteúdo de carbono ou de nitrogênio. $\mathrm{O}$ desmatamento e cultivo contínuo levam, geralmente, a uma redução nesses conteúdos, dependendo das condições edafoclimáticas e do agrossistema estabelecido.

Ocorre também um aumento progressivo do carbono proveniente do agrossistema, devido à entrada de seus restos vegetais no solo, ao passo que o carbono remanescente da vegetação natural, vai se perdendo pela mineralização.

- Através de técnicas isotópicas, que se baseiam na mudança entre a vegetação nativa, de tipo fotossintético $\mathrm{C}_{3}$ e a cultura estabelecida, de tipo fotossintético $\mathrm{C}_{4}$, ou vice-versa, é possível identificar qual a fonte da matéria orgânica, como também as frações estável e biodegradável da matéria orgânica. A fração biodegradável é importante na manutenção dos microrganismos do solo, os quais apresentam papel fundamental na fertilidade do solo e na nutrição das plantas devido ao processo de decomposição da matéria orgânica e da conseqüente mineralização dos nutrientes.

A quantificação da biomassa microbiana permite acompanhar muito mais rapidamente as mudanças das propriedades biológicas do solo decorrentes do manejo, pois reage com maior rapidez do que os parâmetros fisico-químicos. Um bom indicativo dessas mudanças são as quantidades de gases que os sistemas com nova cobertura vegetal começam a evoluir, principalmente o $\mathrm{CO}_{2}$, indicativo da ciclagem dos nutrientes e um dos gases que estão ligados ao efeito estufa, o que é objeto de interesse de estudos.

O reconhecimento da importância dos microrganismos no funcionamento dos ecossistemas, está aumentando o interesse em se medir os níveis de nutrientes imobilizados em sua biomassa e as taxas nas quais são ciclados. 
Desta forma, o conhecimento das alterações do conteúdo de carbono e nitrogênio, das origens da matéria orgânica no solo e o comportamento da fração microbiana do solo, podem ser um instrumento muito útil para se entender melhor o ciclo da matéria orgânica.

A estruturação do solo é afetada, pois o mesmo passará por um preparo, a cultura vai apresentar diferenças quanto ao material depositado para a decomposição e o próprio sistema radicular pode contribuir para esta alteração. Torna-se, portanto, necessário avaliar a influência sobre a estruturação do solo ocasionada pela substituição da mata nativa por outra cultura.

Esse trabalho visa analisar as consequiências da ocupação agrícola sobre as propriedades de um solo(areia quartzosa álica), de grande ocorrência nessa área da bacia do Rio Piracicaba, através do levantamento de parâmetros fisicos, químicos e biológicos do solo. Como objetivo geral, pretende-se analisar os impactos da utilização do solo com as diferentes culturas, e mais especificamente, verificar as variações químicas em termos de estoque de $\mathrm{C}$ e $\mathrm{N}$, caracterizar as variações biológicas em termos de biomassa microbiana do solo, quantificar a evolução de gás carbônico $\left(\mathrm{CO}_{2}\right)$ e metano $\left(\mathrm{CH}_{4}\right)$ e verificar as alterações da estabilidade dos agregados do solo.

Todas essas variações decorrentes dos vários tipos de culturas instaladas na área, serão comparadas entre si e com a mata nativa e, ainda, serão relacionados os parâmetros analisados para melhor compreender a dinâmica da matéria orgânica do solo.

Para este estudo, escolheu-se uma área localizada no município de São Pedro, na porção final da bacia do Rio Piracicaba, na qual as atividades agro-silvo-pastoris ocupam cerca de setenta e cinco por cento da área de drenagem, destacando-se a canade-açúcar e as pastagens; a cobertura florestal representa apenas doze porcento de sua ocupação. Essa escolha deu-se pelo fato da região apresentar as principais culturas da bacia em termos de ocupação (cana-de-açúcar e pastagem), e possuir ainda uma área utilizada para reflorestamento comercial (Eucaliptus saligna), como também um remanescente da vegetação nativa, o qual servirá de parâmetro de comparação para os resultados obtidos. 


\section{REVISÃO DE LITERATURA}

\subsection{A intensificação da agricultura e as modificações no ambiente}

A substituição das matas naturais por culturas agrícolas vem ocorrendo ao longo dos anos. A mudança na vegetação causa uma alteração no ecossistema, modificando as propriedades do solo, as quais variam com as condições de clima, espécie vegetal e natureza do próprio solo.

Os solos respondem de maneiras diferenciadas aos diversos sistemas de cultivo, manejo e tempo de uso. Estas respostas são quantificadas através da avaliação das modificações nas suas propriedades físicas, químicas e microbiológicas. Além disso, a influência da cultura introduzida dependerá da qualidade e da quantidade dos resíduos lançados ao solo.

A bacia do Rio Piracicaba ocupa uma área de $12.400 \mathrm{Km}^{2}$, é dividida em três sub-bacias:

- Sub-bacia do Rio Piracicaba, que ocupa 545.694 ha ou $48 \%$ do total, dos quais 409.372 ha correspondem à área cultivada (54\%) e apresenta $75 \%$ de toda a área ocupada da bacia. É nesta sub-bacia que se localiza o município de São Pedro;

- Sub-bacia do Rio Jaguari, que ocupa 296.113 ha ou $26 \%$ da bacia, com 183.869 ha de área cultivada (24\%) e ocupação de $62 \%$;

- Sub-bacia do Rio Atibaia, compreendendo 296.055 ha o que equivale a $26 \%$ da bacia, tendo como área cultivada 168.109 ha (22\%) e ocupação de 57\% (São Paulo, 1994).

Intensas transformações ambientais vêm ocorrendo na bacia do Rio Piracicaba, decorrentes do crescimento e desenvolvimento da região. Uma das principais causas das transformações ambientais foi a expansão agrícola, ocorrida graças às liberações de créditos agrícolas nas últimas três décadas. 
Nesse período, cresceram as culturas exportáveis (laranja e soja) e a cana-deaçúcar principalmente, devido ao PROÁLCOOL que visava uma outra fonte de energia para ser usada como combustível. Houve ainda um aumento de produtividade em culturas como arroz, cebola, batata, tomate e frutas. Com relação à pecuária houve aumento nas áreas com pastagens cultivadas, visando a criação de gado para corte e leite.

Nos últimos vinte anos a área de cobertura florestal - eucalipto e cerrado - tem apresentado, também, um ligeiro crescimento, principalmente em alguns municípios da sub-bacia do Rio Corumbataí (Analândia, Corumbataí, Ipeúna, Rio Claro e Santa Gertrudes)

No geral, dentre as atividades agro-silvo-pastoris, destacam-se as pastagens naturais e cultivadas, com $45 \%$ de ocupação e lavoura temporária com $32 \%$, representada quase que totalmente pelo cultivo da cana-de-açúcar.

Devido a ocorrência de uma modernização e intensificação agrícola na região, aumentando a conversão de áreas com vegetação nativa em áreas com culturas agrícolas (pastagem e cana-de-açúcar principalmente), como mostra a Tabela 1, possibilitou mudanças na qualidade ambiental da região.

\subsection{Alterações nas propriedades do solo em consequência do cultivo e do manejo}

A substituição da vegetação natural por culturas agrícolas, vem ocorrendo ao longo dos anos, causando desequilíbrio no ecossistema, modificando as propriedades dos solos, as quais variam com as condições de clima, espécie vegetal e natureza do próprio solo. Os solos respondem diferentemente aos diversos sistemas de cultivo, manejo e tempo de uso.

As respostas à substituição da vegetação são quantificadas através da avaliação das modificações nas propriedades químicas, fisicas e microbiológicas destes solos. 
Tabela 1. Porcentual de ocupação da área agrícola - Bacia do Rio Piracicaba.

\begin{tabular}{|c|c|c|c|}
\hline CATEGORIA & SUBCATEGORIA & TIPO & $\%$ \\
\hline \multirow{4}{*}{ LAVOURA } & & Cultivos olerícolas e & \\
\hline & TEMPORÁRIA & hortícolas anuais e & 32 \\
\hline & & plurianuais & \\
\hline & PERMANENTE & $\begin{array}{l}\text { Fruticultura e outras } \\
\text { culturas de ciclo longo }\end{array}$ & 9 \\
\hline \multirow{2}{*}{ PASTAGEM } & NATURAL & - & 23 \\
\hline & CULTIVADA & - & 22 \\
\hline COBERTURA & NATURAL & Mata, Cerrado e Cerradão & 7 \\
\hline FLORESTAL & REFLORESTAMENTO & Pinus, Eucalipto & 7 \\
\hline
\end{tabular}

Fonte: Instituto de Economia Agrícola - IEA ( São Paulo, 1994)

\subsubsection{Alterações nas propriedades químicas do solo}

Com a retirada da vegetação nativa e o subsequente cultivo dessas áreas, ocorrem alterações no estoque da matéria orgânica. Tais alterações vão depender de vários fatores, como a classe do solo, a fertilidade inicial, o comportamento físico-químico de cada nutriente, suas interações com o meio, a cultura introduzida, como também o manejo e os tratos culturais adotados.

Segundo Lavelle et al (1992), os solos podem ser mais ou menos férteis ou sensiveis ao uso agrícola, dependendo do seu material de origem (rocha mãe, que fornece nutrientes e determina a textura do solo) e dos fatores climáticos (que controlam a intensidade de formação do solo).

Com os sucessivos e contínuos ciclos de cultivo e atividades de preparo do solo, as condições originais de estrutura e disponibilidade de nutrientes são perdidas, e a manutenção da fertilidade passa a depender de insumos. Eles devem promover uma taxa de mineralização que liberem nutrientes em quantidades suficientes para a nutrição das 
plantas, evitando perdas por lixiviação e estimulem a produção de substâncias agregantes que beneficiem a estruturação do solo.

Cunningham (1963), pesquisando o efeito da retirada da mata sobre a dinâmica dos nutrientes em solos tropicais, constatou diminuição nos teores de carbono orgânico, nitrogênio, fósforo e CTC (capacidade de troca de cátions), devido ao aumento da temperatura do solo, que proporciona uma rápida decomposição da matéria orgânica e à não reposição da mesma.

Cerri (1986), realizando trabalhos em solos cultivados, observou que o cultivo após o desmatamento é frequentemente responsável por uma redução nos estoques de matéria orgânica do solo, que passará a ser citada como MOS, sendo essa diminuição mais acentuada nos primeiros anos de cultivo, bem como alterações na CTC e pH.

Vários autores, trabalhando com diferentes solos, constataram que a substituição da mata nativa por culturas, afeta as propriedades químicas do solo, exceto naqueles casos em que um bom manejo é feito. A principal alteração está relacionada à exportação de nutrientes pelas culturas, que em parte pode ser diminuída com a incorporação dos restos vegetais.

\subsubsection{Alterações nas propriedades físicas do solo}

A interação entre microrganismos, raízes de plantas, polissacarideos e compostos húmicos aromáticos com partículas minerais primárias, dá origem aos macro $\mathrm{e}$ microagregados, base da estrutura do solo. A vulnerabilidade do solo à lixiviação, erosão e outros impactos está intimamente relacionada à sua estrutura.

As práticas de manejo influenciam diretamente o tamanho, a distribuição e a estabilidade dos agregados do solo. Por mais simples que sejam as práticas culturais, elas podem resultar na pulverização da camada superficial.

Quanto mais intensa for a movimentação do solo provocada pelo sistema de cultivo, menor será o diâmetro médio dos agregados. A mudança da estrutura é talvez a transformação mais importante que ocorre com a morfologia do solo quando da substituição da mata nativa por culturas. 
Os agregados biológicos e a estrutura em grumos do solo, tendem a desaparecer com o cultivo, já que ocorre uma redução na quantidade de matéria orgânica, onde a biomassa microbiana tem um papel importante, como produtora de agentes cimentantes dos agregados.

Essa tendência ao desaparecimento é devido ao preparo do solo (aração e gradagem), e ao impacto das gotas de chuva, principalmente na camada superficial, causando um aumento dos microagregados. A exceção que ocorre é quanto ao cultivo com pastagem, devido ao vigoroso sistema radicular que esta cultura apresenta, que proporciona uma maior proteção ao solo.

A estrutura propicia condições essenciais ao desenvolvimento vegetal, afetando a disponibilidade de água e minerais, a aeração, a atividade da fauna e da flora do solo e o crescimento das raízes. Sua alteração provoca modificações na relação solo/planta, afetando o crescimento das culturas e a sua produtividade (Oades, 1984).

A ação da matéria orgânica na estabilidade estrutural do solo está intimamente ligada à atividade microbiana. Baver et al. (1972) citam que somente o material orgânico, sem transformação biológica, não tem qualquer efeito sobre a estrutura do solo.

Os microrganismos do solo participam da agregação tanto aproximando partículas entre si, como produzindo polissacarídeos e outras substâncias orgânicas que atuam como goma ou cimento. O primeiro mecanismo de aproximação forma os agregados e o segundo lhes dá estabilidade (Alisson, 1968).

Cerri (1986) relata que segundo vários autores, a diminuição da estabilidade da estrutura dos solos cultivados está diretamente relacionada ao decréscimo do teor de MOS, notadamente em húmus, a qual apresenta papel fundamental na estabilização dos agregados do solo, e sugere que a incorporação dos restos vegetais da cultura no solo atenuam as perdas de matéria orgânica.

As mudanças no uso do solo podem provocar um aumento na densidade deste, o que pode acarretar a médio e longo prazo, a compactação, pois, a densidade influencia diretamente a resistência à penetração de raízes e a difusão de oxigênio.

Desta forma, as propriedades físicas do solo como a densidade, porosidade e a agregação, são facilmente alterados com o cultivo estabelecido após a retirada da 
vegetação nativa. Através de um manejo adequado, inclusive com a adição de matéria orgânica, pode-se manter ou melhorar as propriedades fisicas do solo, as quais afetarão diretamente o desenvolvimento das culturas.

\subsubsection{Considerações sobre o método de avaliação da estabilidade dos agregados}

O principal fator que determina a distribuição do tamanho dos agregados é a maneira como a massa do solo é rompida (Kemper \& Chepil, 1965).

Angulo et al. (1984) propõem que a determinação da estabilidade dos agregados deve utilizar em laboratório, forças de desintegração da massa do solo semelhantes àquelas existentes no campo. Acrescentam que o método mais adequado parece ser o de peneiramento em água.

Kemper (1965) observou que no método da imersão direta simulam-se as forças de desintegração encontradas em condições de inundação e de erosão laminar, sendo estas as formas de desintegração que comumente ocorrem nos solos dos trópicos, sujeitos a fortes chuvas durante boa parte do ano.

Camargo et al. (1986) acreditam que o embebimento da amostra em álcool permite inferências acerca do efeito das cargas do solo sobre a agregação, e que o embebimento em benzeno proveria uma maior compreensão do papel desempenhado pela matéria orgânica e seus compostos.

\subsection{O papel da matéria orgânica na dinâmica do solo e as mudanças devido ao uso} do solo

A matéria orgânica do solo constitui um sistema dinâmico que se modifica a cada novo tipo de uso ao qual o solo é submetido.

É constituída primordialmente por restos vegetais e animais em vários estágios de decomposição: húmus, que é o produto da degradação bioquímica desses resíduos. $\mathrm{O}$ húmus contém, senão todos, a maioria dos compostos bioquímicos sintetizados por organismos vivos (Stevenson, 1982).

Alguns organismos, principalmente a biomassa microbiana atuante nos processos de decomposição; e os rizodepósitos que são as substâncias orgânicas liberadas 
pelas raizes das plantas vivas. Cada um desses constituintes apresenta uma dinâmica particular no solo (Cerri, 1989).

A MOS pode ainda ser dividida em substâncias húmicas e não húmicas. Substâncias não húmicas, sintetizadas pelos animais e vegetais que não sofreram transformações, são constituídas por compostos pertencentes a classes bioquímicas definidas: aminoácidos, carboidratos, graxas, ceras, resinas, ácidos orgânicos etc.

As substâncias húmicas consistem de uma série de polímeros de peso molecular relativamente alto (ácidos fúlvicos, ácidos húmicos e huminas), são resultantes da recombinação de produtos aromáticos, aminoácidos e aldeídos. Possuem coloração escura entre o marrom e o preto.

Como já visto anteriormente, a matéria orgânica desempenha papel fundamental na agregação do solo, já que o efeito agregante de materiais orgânicos rapidamente decompostos pelos microrganismos, tais como glicose e polissacarídeos, aumentam a estabilidade estrutural, mas tem efeito pouco duradouro. Materiais com decomposição mais lenta conferem um caráter mais duradouro à agregação.

$\mathrm{O}$ fracionamento químico dessas substâncias tem sido feito, classicamente, com base nas suas características de solubilidade em ácidos e álcalis, obtendo-se três compostos principais: humina (insolúvel em alcali e ácido), ácido húmico (solúvel em álcali e insolúvel em ácido) e ácido fúlvico (solúvel em álcali e ácido).

Essas três frações possuem características diferentes quanto ao grau de polimerização, peso molecular e acidez total, o que confere diferenças entre solos que possuam diferentes proporções delas (Stevenson, 1982).

A decomposição da matéria orgânica (resíduos animais e vegetais) do solo, constitui um processo biológico básico, que irá garantir a reposição dos nutrientes ao solo, tornando-os disponiveis às plantas e o carbono é liberado para a atmosfera na forma de $\mathrm{CO}_{2}$.

Dois processos fundamentais ocorrem na transformação dos resíduos orgânicos do solo: a mineralização e a humificação. A mineralização da matéria orgânica humificada ou não, refere-se à formação de compostos minerais, em geral solúveis (fosfatos, sulfatos, nitratos e outros) ou gasosos $\left(\mathrm{CO}_{2}\right.$ e $\left.\mathrm{NH}_{3}\right)$, pela ação de microrganismos. 
Neste processo uma parte dos nutrientes é assimilada pelo microrganismos e através do processo de mineralização, é reutilizada. Contudo, a mineralização não é completa e uma grande parte destes compostos orgânicos é modificada, formando complexos orgânicos resistentes que juntos com os constituintes microbianos e outros produtos resistentes do metabolismo constituem a matéria orgânica do solo.

Já na humificação, a matéria orgânica fresca é subdividida mecanicamente ou é enterrada nos horizontes minerais pela atividade de animais que habitam o solo, sendo transformada rapidamente pelos microrganismos do solo em compostos intermediários (precursores húmicos).

Durante estes processos, a matéria orgânica acumula-se sobre a superficie do solo e no interior do primeiro horizonte orgânico-mineral, constituindo, assim, o húmus em sentido amplo. A estrutura do húmus é resultante da interação do substrato mineral do solo e os compostos orgânicos, sendo esta interação influenciada pelas condições climáticas globais (Garay \& Silva, 1993)

A matéria orgânica do solo representa um dos materiais mais complexos existentes na natureza, sendo um componente chave para a maioria dos processos biológicos que ocorrem nos solos de ecossistemas florestais (Luizão \& Schubart, 1987; Geraldes, 1993).

- Em solos de ecossistemas tropicais e intertropicais, os quais naturalmente são pobres em nutrientes, e cuja principal fonte destes nutrientes é a decomposição dos resíduos culturais, com a conseqüente mineralização desses nutrientes, alterações na dinâmica da decomposição da MOS pode levar a queda da produtividade, que possivelmente será recuperada com a utilização de insumos.

Nos ecossistemas naturais as perdas de matéria orgânica, decorrentes dos processos de mineralização, são compensadas pela humificação dos restos vegetais, que naturalmente são incorporados ao solo. Diz-se então que o sistema solo apresenta um equilíbrio dinâmico, resultando portanto num conteúdo praticamente constante de matéria orgânica em função do tempo (Cerri, 1989). 
A mudança da cobertura vegetal do solo devido à substituição da vegetação natural por culturas, como também as práticas culturais realizadas, afetam a microbiota do solo, alterando sua atividade e, assim, a decomposição da matéria orgânica.

Devido ao aumento das áreas cultivadas e modificações das coberturas vegetais, deve existir uma preocupação com o uso racional da terra. Nos cultivos, a retirada contínua de nutrientes do solo pelas plantas, afeta a médio e longo prazos, a manutenção da produtividade, provocando mudanças nos horizontes húmicos e na fertilidade do solo que necessitam ser avaliadas com precisão (Nepstad et al, 1991).

Nos agrossistemas, a quantidade de resíduos incorporados ao solo é geralmente menor que nos ecossistemas naturais. As perdas por mineralização nos agrossistemas são também maiores devido às temperaturas mais elevadas que se registram na superficie do solo descoberto. Como resultado, observa-se um declínio na quantidade de matéria orgânica do solo em função do tempo de cultivo (Stevenson, 1982).

Em relação às mudanças decorrentes da alteração do ecossistema florestal, verifica-se que o uso e o manejo do solo alteram não só a quantidade mas também a qualidade da MOS e, inicia um processo de mineralização da matéria orgânica biodegradável, o que ocasiona uma redução no estoque de carbono nos primeiros anos após o desmatamento.

Com a implantação de um sistema de cultivo, o estoque de carbono pode ser recuperado ao longo do tempo, com a entrada dos resíduos vegetais da cultura, variando com as propriedades fisicas e químicas do solo.

A natureza dos resíduos tem influência na qualidade da matéria orgânica, os mais ricos em nitrogênio são rapidamente decompostos, e a decomposição mais rápida ou mais lenta do resíduo influencia não apenas o conteúdo, como também favorece a síntese de determinadas frações do húmus em detrimento de outras.

$\mathrm{O}$ teor de MOS decresce com a profundidade, bem como com a intensidade de cultivo do solo (Coelho, 1990). A diminuição de MOS sob cultivo, segundo Stevenson (1982), não pode ser atribuída unicamente à redução da quantidade de resíduos vegetais disponiveis para a síntese de húmus, mas também à melhoria da aeração e a alternância de 
umidecimento e secagem, fenômenos tais que podem levar ao aumento da atividade microbiana e à perda de matéria orgânica.

Cerri \& Moraes (1992), realizando estudos sobre a dinâmica da matéria orgânica em sistemas de floresta-pastagens na região de Ouro Preto do Oeste-RO, em dois solos, um Podzólico Vermelho-escuro e um Podzólico Vermelho-amarelo, constataram uma redução no conteúdo de carbono após o desmatamento, que poderia estar associado à rápida mineralização do húmus biodegradável do solo logo após o desmatamento e à lenta incorporação de novas fontes de carbono derivadas da pastagem; esse conteúdo de carbono do solo é recuperado com o passar do tempo, mais rapidamente no solo mais arenoso.

O manejo do solo e as práticas culturais realizadas nas mais diferentes culturas, agirão direta e indiretamente sobre a atividade dos microrganismos e consequentemente, sobre o processo de decomposição da matéria orgânica, devido à influência deste manejo e das práticas culturais sobre as propriedades do solo como temperatura, umidade, densidade, aeração, porosidade, $\mathrm{pH}$ e teor de nutrientes minerais.

Segundo Selbach (1989), a acidez do solo ( $\mathrm{pH}$ e alumínio trocável) tem sido apontada como uma das propriedades químicas que mais influencia a atividade biológica e conseqüentemente, a decomposição da MOS.

O efeito da acidez do solo sobre os processos microbiológicos está também associada à disponibilidade dos nutrientes, a qual é reduzida em solos ácidos. Sabe-se que a calagem, correção do $\mathrm{pH}$ do solo utilizando cal, é fator importante para aumento da atividade biológica e na decomposição da matéria orgânica.

A matéria orgânica também atua de maneira importante nas propriedades químicas e físicas do solo, aumenta a CTC (capacidade de troca de cátions) do solo e conseqüentemente a retenção de nutrientes, favorecendo a absorção de alguns micronutrientes, aumentando a retenção de água, melhorando a agregação do solo e diminuindo o efeito de elementos tóxicos.

Chaney \& Swift (1984), afirmam que os níveis de matéria orgânica do solo podem ser utilizados no diagnóstico para identificar solos com problemas de instabilidade estrutural. Esses autores trabalhando com 26 solos na Inglaterra, obtiveram uma 
correlação altamente significativa $(\mathrm{r}=0,9)$ entre a estabilidade de agregados e a matéria orgânica do solo.

Desse modo o manejo e a conservação desses solos, dependem da cobertura vegetal, que é responsável direta pelos contínuos aportes orgânicos ao solo.

Interferências na cobertura geralmente provocadas pelo uso e conseqüente desmatamento, acarretarão modificações nos estoques húmicos, ocasionando, no início, uma diminuição desses estoques e em seguida queda na fertilidade.

\subsection{Método Isotópico de Estudo $\left(\delta^{13} \mathrm{C}\right)$}

Nos ecossistemas naturais o carbono orgânico do solo é proveniente exclusivamente dos resíduos vegetais de suas plantas, enquanto que em agrossistemas o carbono apresenta duas origens: uma remanescente da vegetação nativa e outra produzida pela decomposição de seus resíduos vegetais.

A discriminação e quantificação destas duas entradas de matéria orgânica tornou-se possível através de técnicas isotópicas baseadas na abundância natural do ${ }^{13} \mathrm{C}$, onde o $\delta^{13} \mathrm{C}$ da matéria orgânica do solo é derivado da cobertura vegetal que a constitui e a substituição desta vegetação pode provocar mudanças na composição isotópica da matéria orgânica.

$\mathrm{O}$ isótopo ${ }^{13} \mathrm{C}$ perfaz aproximadamente $1 \%$ do carbono na natureza, entretanto sua distribuição pode ser influenciada por processos naturais. Os processos fotossintéticos, por exemplo, discriminam o ${ }^{13} \mathrm{C}$ em favor do isótopo ${ }^{12} \mathrm{C}$ (ciclo de Calvin), $\mathrm{C}_{4}$ (Hatch-Slack) ou CAM (metabolismo ácido crassuláceo) dependendo de sua via fotossintética. As plantas $\mathrm{C}_{3}$, discriminam o ${ }^{13} \mathrm{C}$ mais do que as planta $\mathrm{C}_{4}$, enquanto que as plantas CAM mostram abundância isotópicas variáveis. A maioria das plantas utilizam exclusivamente a via $C_{3}$, já as plantas $C_{4}$ são essencialmente gramíneas tropicais.

A relação ${ }^{13} \mathrm{C} /{ }^{12} \mathrm{C}$ é usualmente expressa na forma $\delta^{13} \mathrm{C}$ por mil (\%o), sendo medida em relação a um padrão. O Padrão (PDB) é uma belemita de uma formação do Cretáceo localizada na Carolina do Sul. Os valores de ${ }^{13} \mathrm{C}$ das plantas $\mathrm{C}_{3}$ e $\mathrm{C}_{4}$ são em média - $28 \%$ e $-12 \%$, respectivamente. 
A partir dessa diferença, mudanças na dominância de ecossistemas por esses dois grupos de plantas podem ser usadas em estudos sobre a dinâmica da matéria orgânica em períodos relativamente longos (Cerri, 1986; Andreux et al, 1990) e em estudos sobre a história ecológica de paisagens (Dzurec et al, 1985), visto que a matéria orgânica do solo, na maioria dos casos, reflete a composição isotópica da vegetação.

Para o emprego desta metodologia são necessárias algumas condições específicas: os perfis do solo devem ser homogêneos com variações mínimas entre um perfil e outro; o cultivo do solo com determinada cultura deve ser contínuo e a vegetação nativa e a cultura devem possuir ciclos fotossintéticos diferentes.

Um exemplo da aplicação desse método pode ser visto no trabalho de Cerri(1986), onde o autor estudou uma sucessão floresta tropical-canavial.

As proporções de carbono derivado da floresta e da cana-de-açúcar foram calculadas a partir de dados de amostras superficiais do solo $(0-20 \mathrm{~cm})$. Foi observado que, após 50 anos de cultivo, a reserva total de carbono tinha decrescido pela metade na camada superficial de solo e a contribuição do material orgânico nas frações mais grosseiras era muito maior do que sob floresta.

O total de carbono derivado da floresta após esse período foi de $21 \mathrm{t} / \mathrm{ha}$, representando apenas $30 \%$ do conteúdo inicial. No entanto, essa quantidade corresponde a $55 \%$ do carbono total do solo cultivado. Os restantes $45 \%$ foram derivados de raízes de cana-de-açúcar e restos de cultura.

Outro exemplo de aplicação pode ser visto no trabalho de Moraes(1991), desenvolvido com solos do estado de Rondônia, onde o autor observou que, após oito anos de uso do solo sob pastagem, apenas $18 \%$ do carbono sob solo PVA, e apenas $9 \%$ sob solo PVE, é derivado da pastagem.

Geraldes (1993), trabalhando com Latossolo Vermelho Amarelo distrófico (LVAd), em Paragominas (RO), cultivados por diferentes períodos com pastagem, observou uma diminuição progressiva do carbono remanescente da floresta e um aumento do carbono proveniente da pastagem. O mesmo pôde ser observado por Fernandes (1993), trabalhando com Podzol Hidromórfico, constatou que após 20 anos de cultivo 
com pastagem, na camada 0-20cm, apenas $29 \%$ do carbono do solo é originário da vegetação nativa.

\subsection{A biomassa microbiana como indicador das alterações nas propriedades do solo}

Jenkinson \& Ladd (1981), definiram a biomassa microbiana como sendo a parte viva da matéria orgânica do solo, excluindo raízes e animais maiores que $5 \times 10^{-15} \mathrm{~cm} \mathrm{e}$, apresenta papel fundamental na manutenção e produtividade de ecossistemas, devido aos processos de decomposição e mineralização da fração orgânica dos nutrientes.

A biomassa microbiana constitui um meio de transformação para todos os materiais orgânicos do solo e atua como reservatório de nutrientes disponíveis às plantas. Com o reconhecimento da importância dos microrganismos do solo, vem aumentando o interesse em se medir os nutrientes contidos em sua biomassa. A estimativa da biomassa, fornece dados úteis sobre mudanças nas propriedades biológicas do solo decorrentes do uso do mesmo.

Powlson et al. (1987) afirmam que a biomassa microbiana é um bom indicador das mudanças do $\mathrm{C}$ orgânico e do $\mathrm{N}$ do solo, dando uma perspectiva do que acontecerá com a matéria orgânica do solo durante o cultivo, e que a biomassa microbiana responde muito mais rapidamente às mudanças de manejo e uso do solo, que representam uma alteração no aporte anual de material orgânico para o solo, do que os parâmetros físicos e químicos.

A biomassa microbiana pode ser uma fração potencialmente mineralizável no solo, segundo Bonde et al. (1988). Com a substituição da mata natural por culturas, há uma diminuição nas entradas de material para a decomposição, devido principalmente a colheita que provoca uma exportação de nutrientes e a não incorporação dos restos vegetais ao solo. Com esta diminuição, a biomassa existente seria mineralizada, e como consequência seria reduzida.

Estudos referentes à estimativas da biomassa microbiana em Latossolos da Amazônia, mostraram que nas condições de mata natural, a biomassa concentra-se nos primeiros $5 \mathrm{~cm}$ do solo. A derrubada e queima da floresta ocasionou uma queda drástica 
na biomassa microbiana e uma inversão de sua distribuição com a profundidade (Cerri et al., 1985b; Penning et al., 1992).

Geraldes (1993) trabalhando em áreas com pastagem, concluiu que a biomassa microbiana concentrou-se na camada superficial, onde a disponibilidade de matéria orgânica é maior, devido a grande quantidade de raízes. Constatou, ainda que esse quadro se altera com o tempo de cultivo, com a biomassa microbiana decrescendo devido às mudanças nas características fisicas do solo, causadas principalmente pela compactação do solo pelo intenso pastoreio.

Neste mesmo trabalho são citados vários autores que constataram uma considerável perda da matéria orgânica e da biomassa microbiana do solo, quando a vegetação natural dos solos é substituída por cultivos.

Sparling \& Ross (1993) relatam que a proporção do C microbiano no C orgânico do solo tem sido sugerido, também, como um índice para o monitoramento de mudanças no solo sob diferentes tipos de cultivos. 


\section{MATERIAL E MÉTODOS}

Neste capítulo, será caracterizada a região estudada, quanto à localização, tipo de clima, solo e relevo, bem como do uso do solo na região. Serão descritas as áreas de estudos, os detalhes das amostragens, a preparação do material e as análises realizadas.

\subsection{Caracterização da região estudada}

A localização e as características do meio físico serão abordadas a seguir.

\subsubsection{Localização da área de estudos}

O estudo de campo foi realizado no município de São Pedro-SP, situado na parte oeste da bacia do Rio Piracicaba. A localização desta bacia no Estado de São Paulo, com a área de estudo e os rios que a formam estão nas figuras 1 e 2.

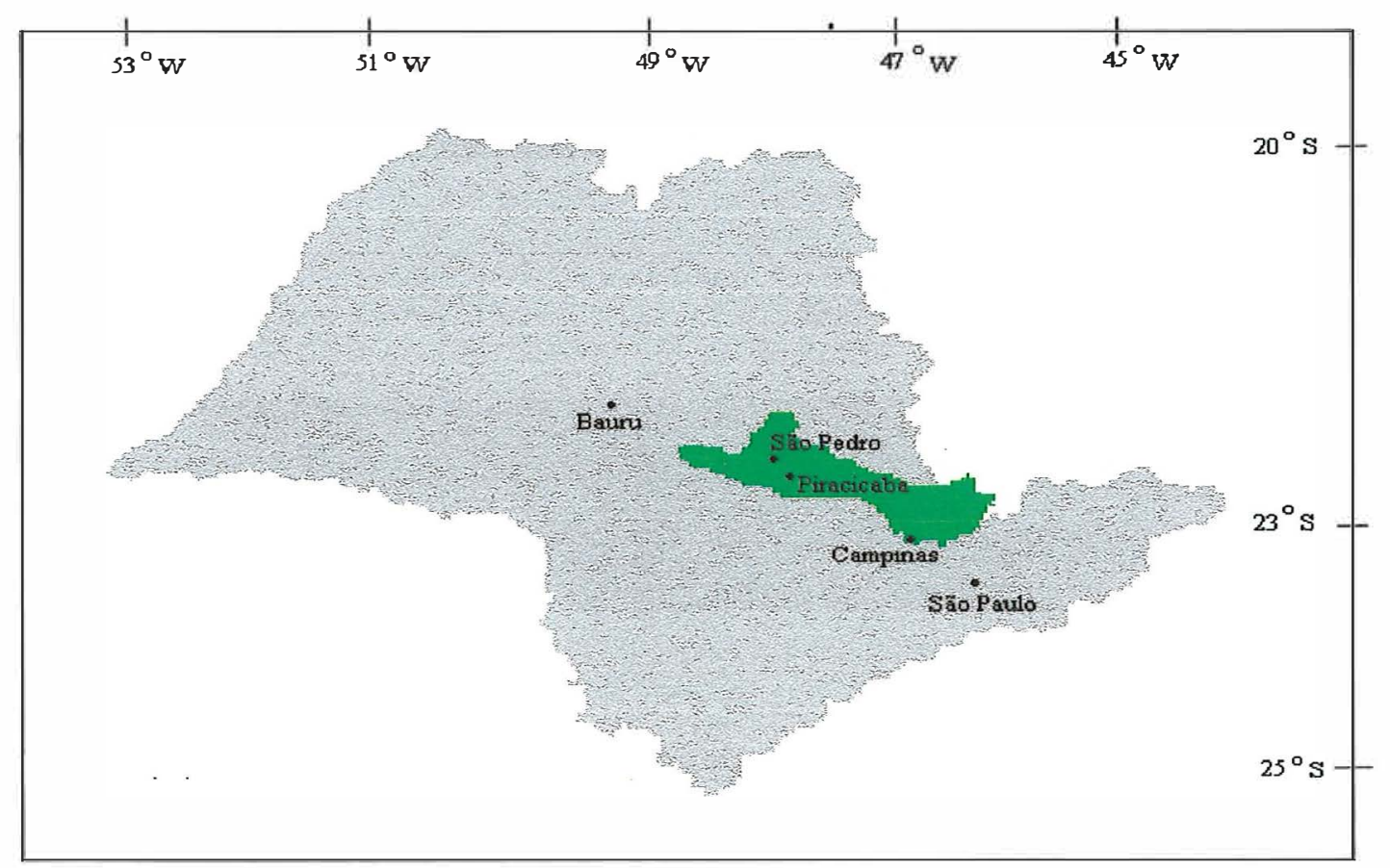

Figura 1 - Localização da bacia do Piracicaba no Estado de São Paulo 


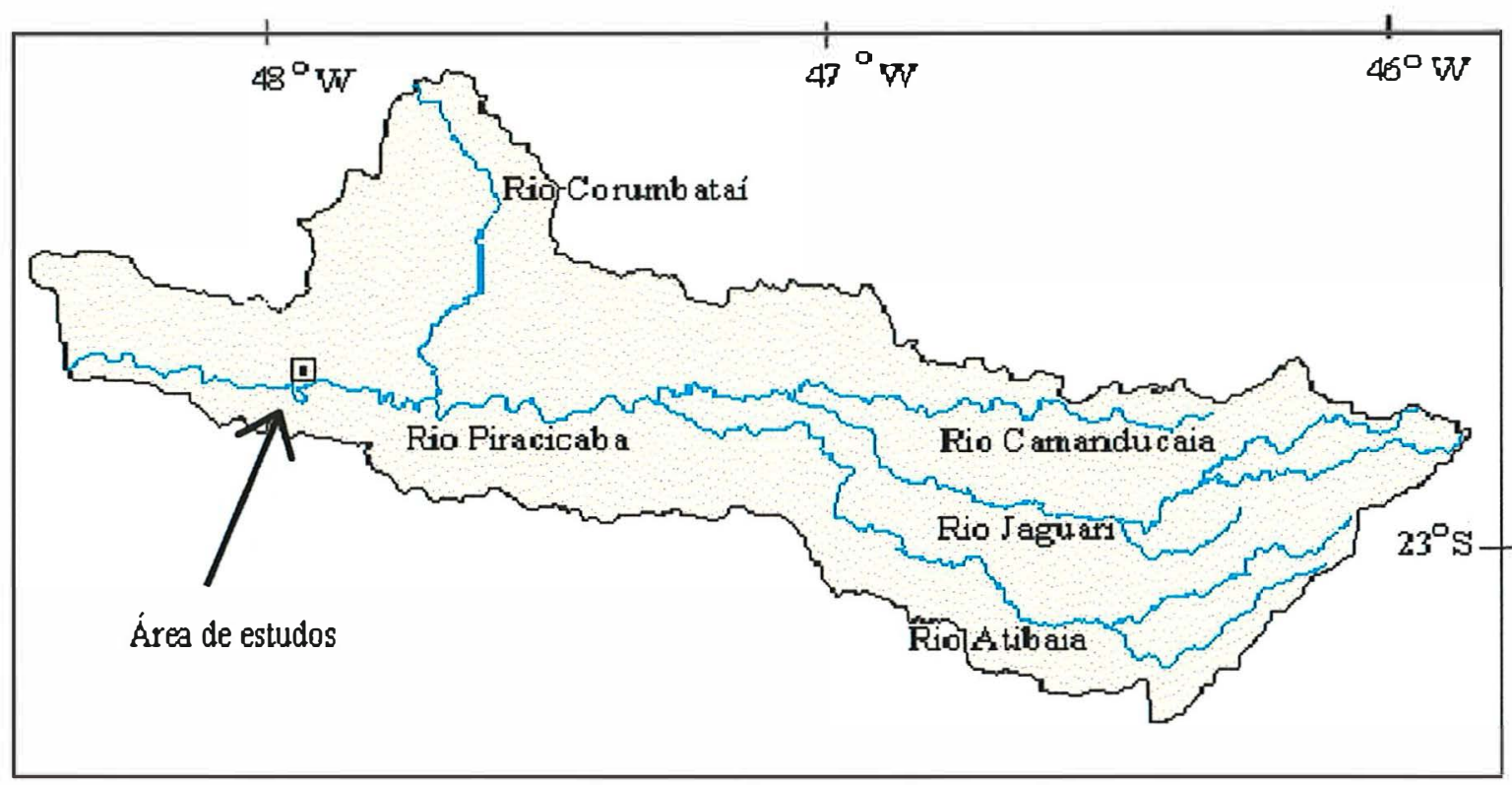

Figura 2-Localização da área de estudos na Bacia do Piracicaba (indicada pela seta).

\subsubsection{Clima, solo e relevo}

O clima da região segundo Köppen é Cwa, clima tropical úmido com 3 meses mais secos (junho, julho e agosto), chuvas de verão, seco no inverno, temperatura do mês mais quente $>22^{\circ} \mathrm{C}$, temperatura média anual $21,1{ }^{\circ} \mathrm{C}$, com uma precipitação média anual de $1.257 \mathrm{~mm}$ (Ometto, 1989).

O relevo é suave ondulado a ondulado, onde as elevações mais altas $(610 \mathrm{~m})$ se encontram na faixa de $150 \mathrm{~m}$ acima das partes mais baixas $(455 \mathrm{~m})$.

Os tipos de solos dominantes na área, definidos na carta de solos da quadrícula de Piracicaba, são o PV-7 (grupamentos indiscriminados de Podzólico Vermelho Amarelo Abrupto), PV-7+Li-5, a AQ (Areia Quartzosa Álica, profunda e pouco profunda, A moderado (Typic Quartzipsomment)) e o Li-5 + PV-7 + PV-8 (Solo Litólico Eutrófico com associações com PV-7 + PV-8), e a área de estudos encontra-se sobre Areia Quartzosa (AQ), e estão apresentados na figura 3. 


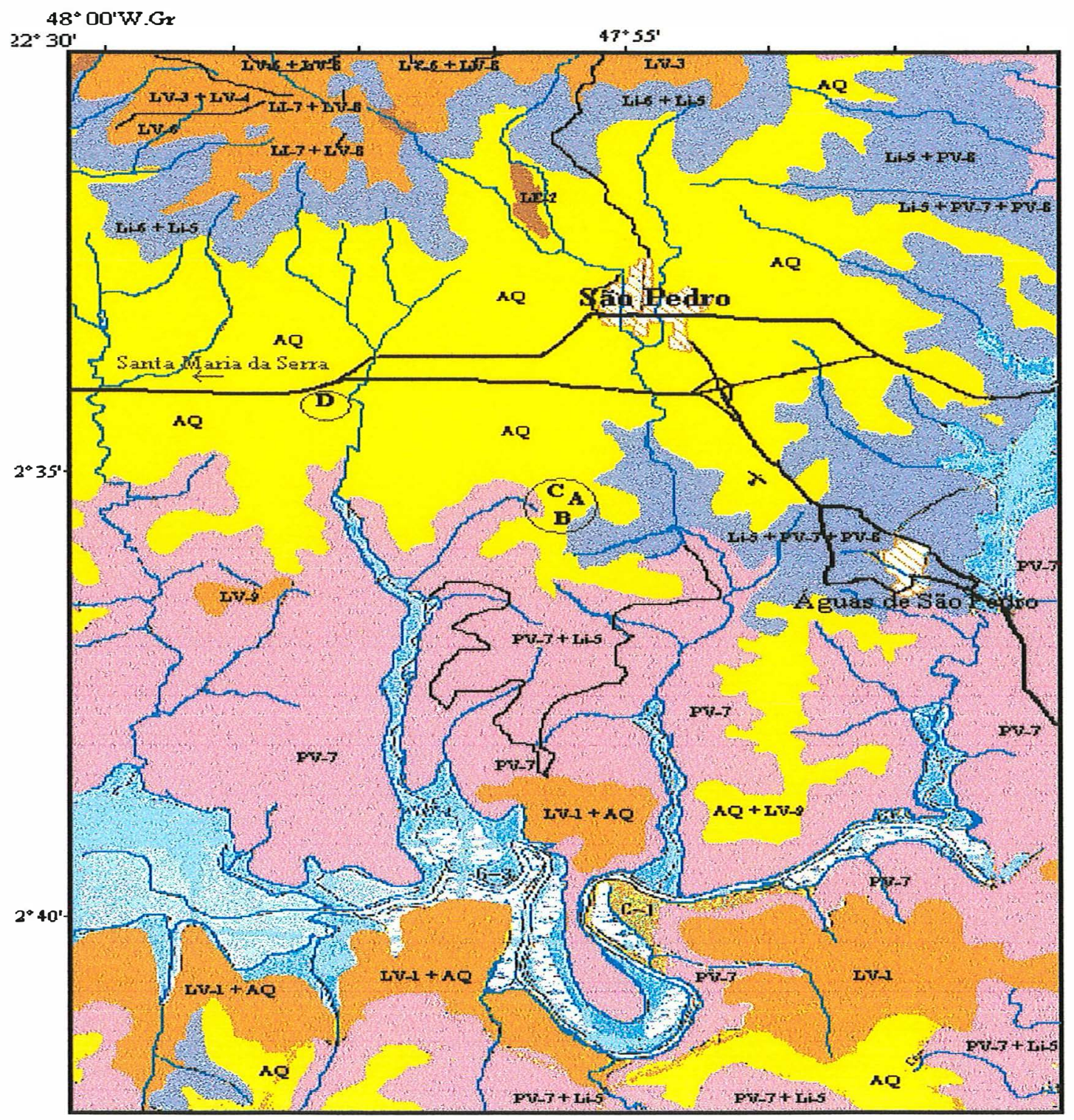

Figura 3 - Solos do Município de São Pedro mapeado ao nível semidetalhado na escala 1:1000.000 (Oliveira, 1989), com as áreas de estudos identificadas pelas letras $\mathbf{A}=$ Mata, $\mathbf{B}=$ Pastagem, $\mathbf{C}=$ Cana-de-açúcar $\mathbf{e}=$ Eucalipto. 


\subsubsection{O Uso da terra na região}

As atividades agro-silvo-pastoris são responsáveis por cerca de setenta e cinco porcento da ocupação do solo na região, destacando-se as pastagens naturais e cultivadas com cerca de quarenta e cinco porcento de ocupação e a lavoura temporária com cerca de trinta e dois porcento representada quase em sua totalidade pelo cultivo da cana-de-açúcar (São Paulo, 1994). A cobertura florestal representa apenas doze porcento de sua ocupação. O mapa de ocupação do solo na bacia do Rio Piracicaba está representado na figura 4.

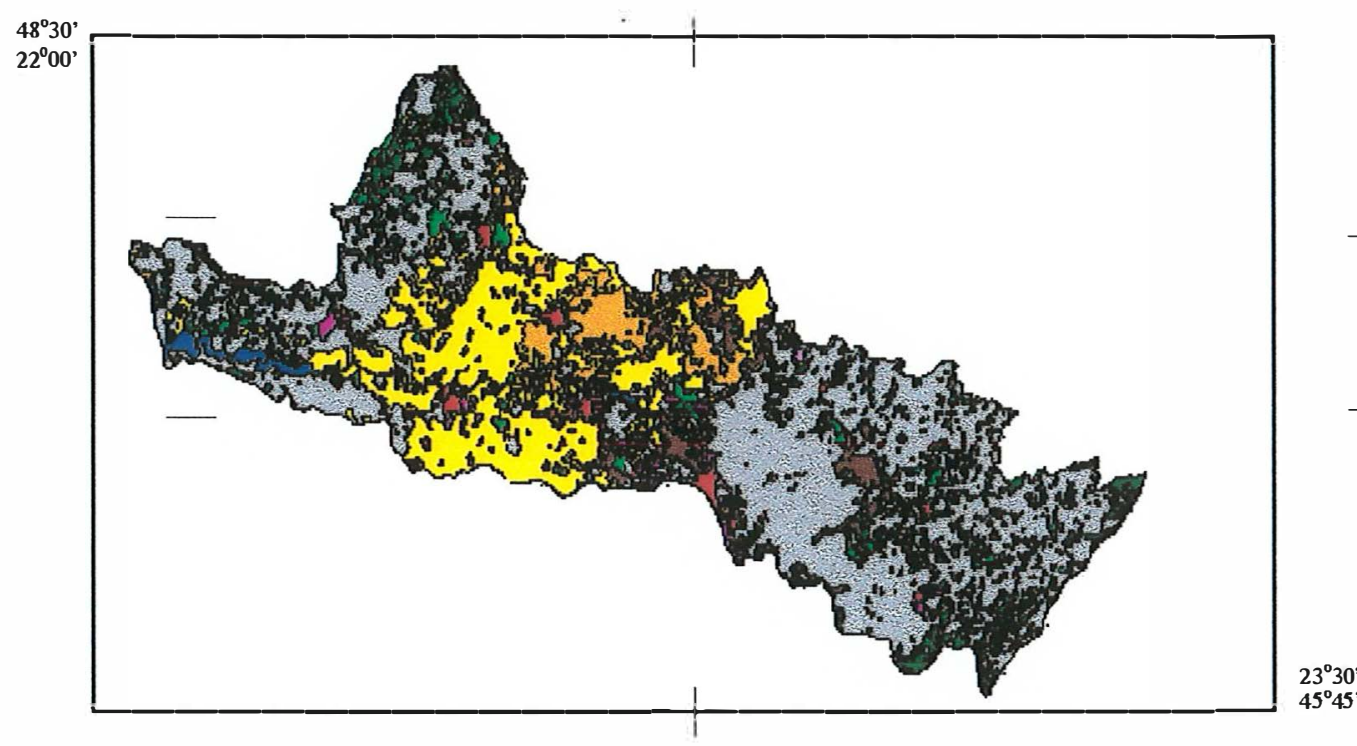

Tipos de Uso

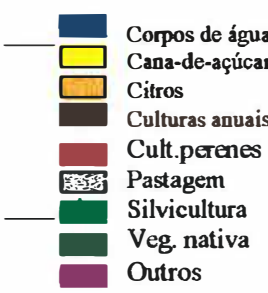

$13013 \mathrm{Km}$

\section{Figura 4 - Mapa do Uso do Solo na Bacia do Rio Piracicaba}

\subsection{Seleção e descrição das áreas de estudos}

A fim de atender aos objetivos deste trabalho, foram escolhidas áreas que representassem a realidade do uso da terra na região, e que as culturas estivessem sobre um mesmo tipo de solo, em situações de cultivo semelhantes. Dessa maneira os resultados obtidos podem ser comparados e servir para estimar a possível influência dessas culturas nas características do solo, quanto à biomassa microbiana $\mathrm{C}$ e $\mathrm{N}$, estoque de carbono e coeficiente de agregação. 
As áreas com cana-de-açúcar, pastagem e mata nativa são próximas uma das outras, localizam-se nos paralelos $22^{\circ} 36^{\prime}$ latitude Sul e $47^{\circ} 58^{\prime}$ longitude Oeste, distantes cerca de 3,5 km da rodovia que liga São Pedro a Santa Maria da Serra, o trevo de acesso a estrada que leva às áreas dista cerca de $3 \mathrm{~km}$ do trevo principal de acesso à cidade de São Pedro pela rodovia SP 304.

A área com eucaliptos dista cerca de $4 \mathrm{~km}$ das primeiras. Localizada nas coordenadas $22^{\mathrm{O}} 34^{\prime}$, de latitude Sul e $47^{\mathrm{O}} 58^{\prime}$ de longitude Oeste, ao lado da rodovia que liga São Pedro a Santa Maria da Serra a cerca de $7 \mathrm{~km}$ do trevo principal de acesso à cidade de São Pedro pela SP 304 (Figura 3).

\subsubsection{Mata nativa}

A mata nativa ( floresta latifoliada semi-decídua), é um remanescente da vegetação natural da região, possui aproximadamente 2,5 ha, e não é um tipo de mata muito fechada, apresenta uma manta de raízes de aproximadamente $4-5 \mathrm{~cm}$, e até a profundidade de $40 \mathrm{~cm}$ apresentava raízes maiores.

A serapilheira, principalmente folhas e alguns galhos, tem em média $3-4 \mathrm{~cm}$. O dossel é regular, entre 15 e 20 metros de altura, o diâmetro a altura do peito (DAP) médio das árvores é de cerca de $20 \mathrm{~cm}$, com um razoável número de cipós, o que indica que a mata está sofrendo um processo de degradação e o sub-bosque, não muito denso dominado por arvoretas.

A mata pertence ao Sítio Antonio Antonelli e há uma estrada de acesso à sede do sítio que passa pelo interior da mata, separando-a em duas partes relativamente iguais. A parte utilizada para os estudos foi a que fica do lado esquerdo da estrada de acesso à sede. 

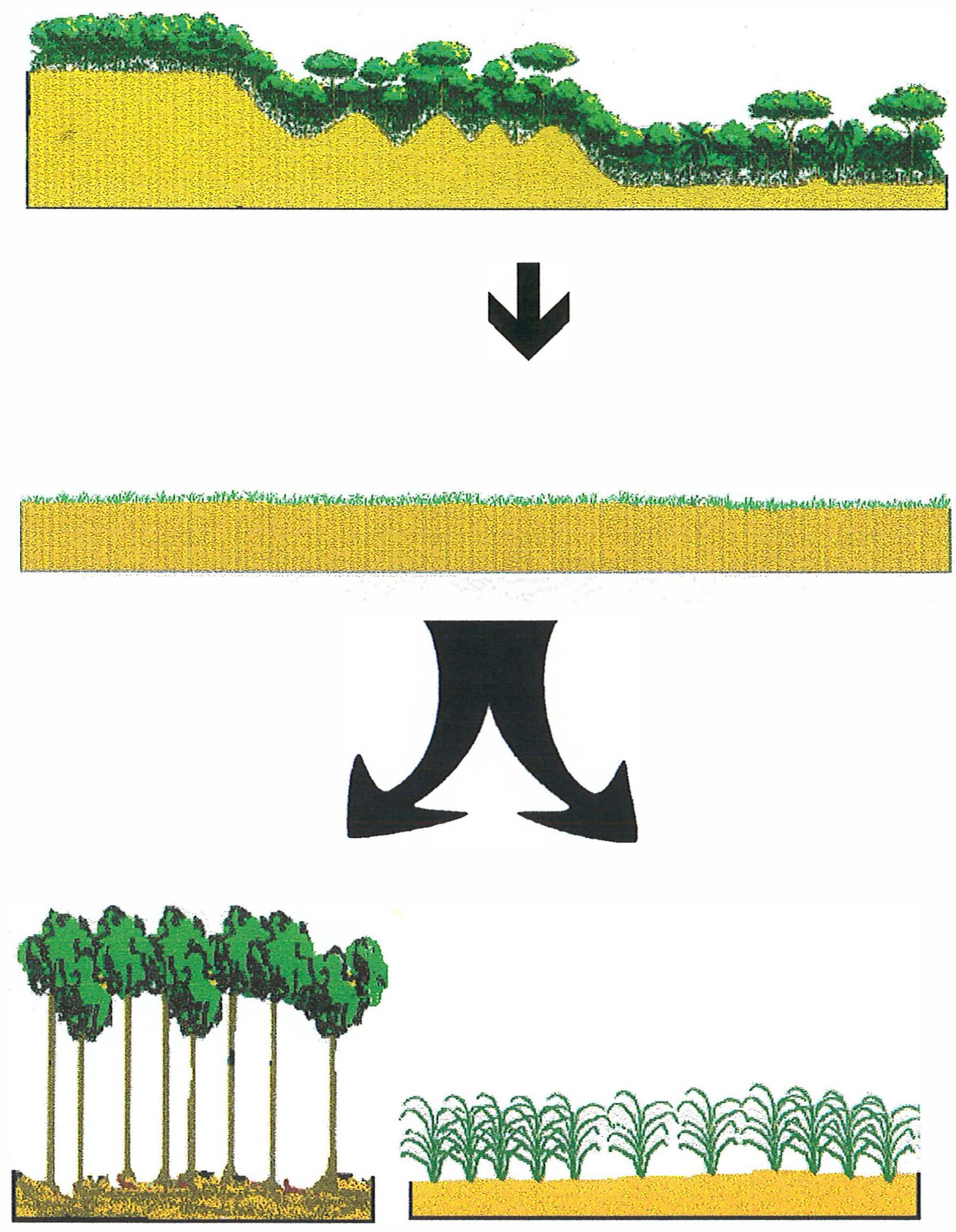

Figura 5 - Representação gráfica da seqüência da implantação das culturas (Mata, Pastagem, Eucalipto e Cana-de-açúcar) 


\subsubsection{Pastagem}

A área com pastagem pertence ao sítio Retiro. No momento da coleta a área não estava sendo utilizada para o pastio. O capim (Brachiara decubens) tinha entre 50-60 $\mathrm{cm}$ de altura, apresentava-se bem formado com reduzida presença de ervas invasoras, e uma camada de raízes mais concentrada nos primeiros $5 \mathrm{~cm}$ de profundidade.

O sítio possui 62,5 ha, e o pastio é feito normalmente por cerca de 80 animais, o que dá uma relação de cerca de 1,3 cabeças/hectare, o gado é utilizado principalmente para recria, mas também para a produção de leite.

A área está sendo cultivada por 18 anos com Brachiaria, anteriormente era formada por pasto natural, não é feito nenhum manejo na área e a fertilização é devido a deposição de dejetos dos animais.

\subsubsection{Cana-de-açúcar}

A área com cana-de-açúcar pertence ao sítio São José. Uma área de aproximadamente 105 ha deste sítio, está sendo cultivada com cana-de-açúcar nos nove anos, totalizando dois ciclos de corte. O uso anterior da terra foi com pastagem, por pelo menos sessenta anos.

O preparo do solo para a substituição da pastagem por cana-de-açúcar deu-se pela forma tradicional, com a utilização de grade pesada, grade curta, grade niveladora, calagem e adubação, atualmente é aplicado calcinado Itaú - PRNT 125\% (1,5 t ha $\left.{ }^{-1}\right)$ a cada colheita, no plantio $496 \mathrm{~kg} \mathrm{ha}^{-1}$, da fórmula 00.25.25 (N, $\left.\mathrm{P}_{2} \mathrm{O}_{5}, \mathrm{~K}_{2} \mathrm{O}\right)$, e no trato cultural, $450 \mathrm{~kg} \mathrm{ha}^{-1} \mathrm{da}$ fórmula 22.00 .20 .

A cana-de-açúcar é da variedade RB-845148, apresentava-se na época da coleta de solo com cerca de dois metros de altura, o que indicava que a queima e o corte da mesma se deu mais para o final da safra (Julho/Agosto) com uma produtividade média de 60 ton/ha, média de quatro cortes. Notou-se também marcas de erosão no terreno, com depósito de areia muito fina nas partes mais baixas do terreno. 


\subsubsection{Eucalipto}

A área com eucalipto (Eucaliptus saligna), pertence à fazenda La Rossana, que é de propriedade da Indústria de Papel Gordinho Braune. O plantio do eucalipto visa a extração de celulose.

A amostragem foi feita em um dos talhões da fazenda, o qual media aproximadamente 50 ha, e dista cerca de dois quilômetros da rodovia que liga São Pedro a Santa Maria da Serra, representado na figura 5.

A área vem sendo utilizada para o plantio de eucalipto desde 1972, e o último corte ocorreu em 1988, e foi o terceiro realizado. Nesta área não foi feito, ainda, nenhum plantio para a reposição de eucaliptos.

$\mathrm{O}$ uso anterior da terra era com pastagem natural, por pelo menos sessenta anos.

\subsection{Amostragem}

\subsubsection{Amostragem de solo}

As amostragens de solo foram realizadas entre os dias 18 e 23 de janeiro de 1996. Com exceção da mata, os demais locais de coleta estão situados a mais de cinqüenta metros das estradas vicinais.

Em cada local amostrado abriu-se uma trincheira de um metro de largura por um metro de comprimento e um metro e meio de profundidade ( $1 \times 1 \times 1,5 \mathrm{~m})$. Do centro de cada trincheira, traçaram-se cinco linhas de coleta com vinte metros de comprimento cada uma, tendo a linha de número um o norte como referência.

Cada linha possuía cinco pontos de coletas, a cinco metros uns dos outros, foram feitas três retiradas de amostras numa linha de cerca de cinqüenta centímetros(Figura 6a) e em cada ponto foram coletadas amostras a cinco profundidades, $0-5 \mathrm{~cm}, 5-10 \mathrm{~cm}, 10-20 \mathrm{~cm}, 20-30 \mathrm{~cm}, 30-40 \mathrm{~cm}$ (Figura 6b). Foram formadas amostras compostas com o material retirado de cada profundidade.

Nas trincheiras foram coletadas amostras nas profundidades: $0-5 \mathrm{~cm}, 5-10 \mathrm{~cm}$, $10-20 \mathrm{~cm}, 20-30 \mathrm{~cm}, 30-40 \mathrm{~cm}, 40-50 \mathrm{~cm}, 60-70 \mathrm{~cm}, 80-90 \mathrm{~cm}$ e $90-100 \mathrm{~cm}$. 


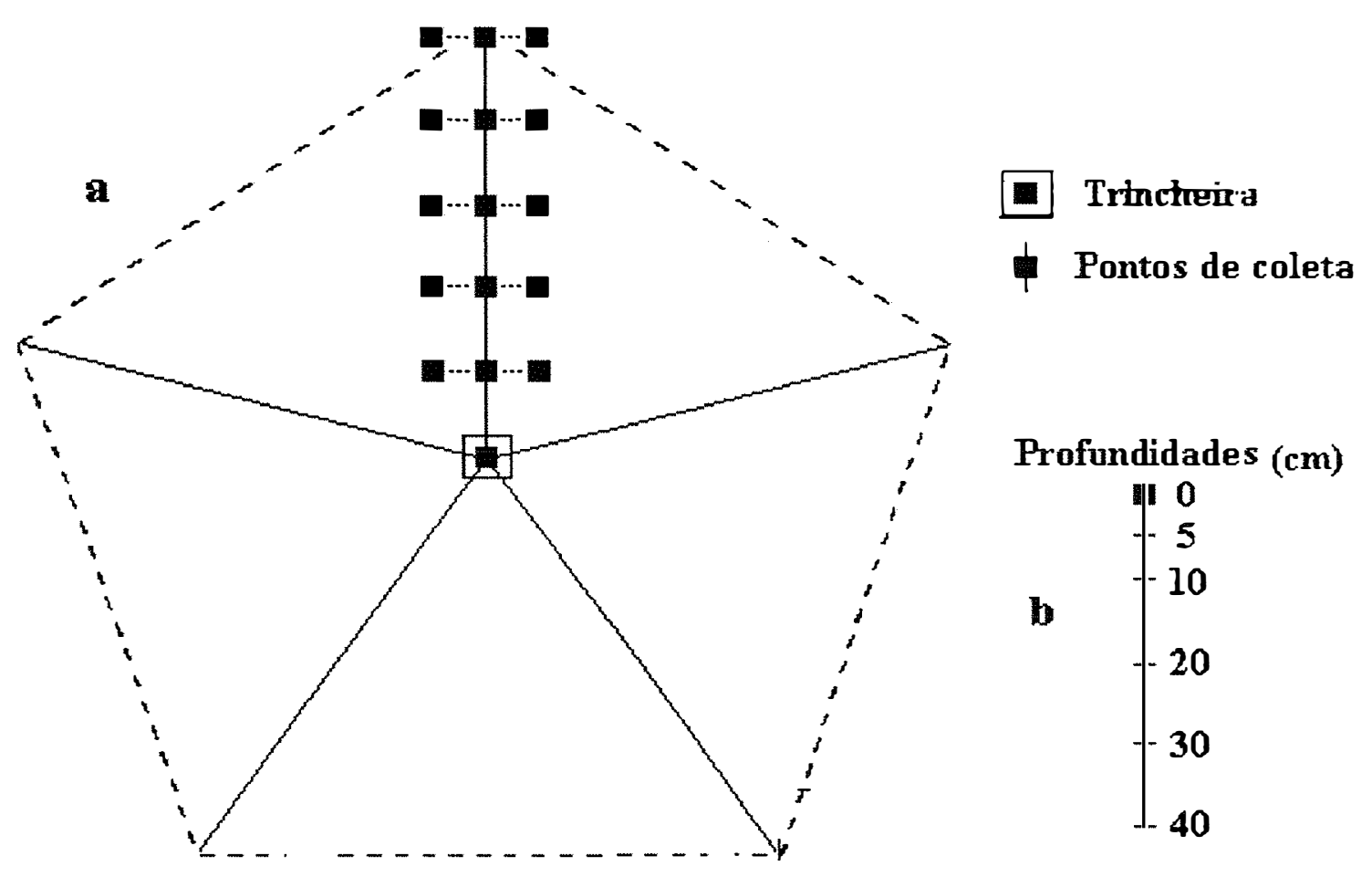

\section{$10 \mathrm{~m}$}

Figura 6 - Representação esquemática da amostragem: a) Configuração da trincheira e linhas de coleta; b) Profundidades amostradas em cada ponto de coleta.

\subsubsection{Amostragem dos Gases}

As amostragens para análises de gases foram realizadas entre os dias 7 e 9 de outubro de 1996. Os locais das coletas foram os mesmos utilizados para as coletas de solo.

Foram instaladas, em cada área de coleta, três câmaras e em cada câmara foram coletadas amostras nos tempos: tempo zero, cinco minutos após o fechamento das câmaras, dez minutos e vinte minutos. As câmaras foram instaladas no chão a cerca de cinco metros uma das outras, era composta de duas partes, a primeira que media cerca de cinco $\mathrm{cm}$ de altura, por trinta e dois centímetros de largura, com vinte e nove 


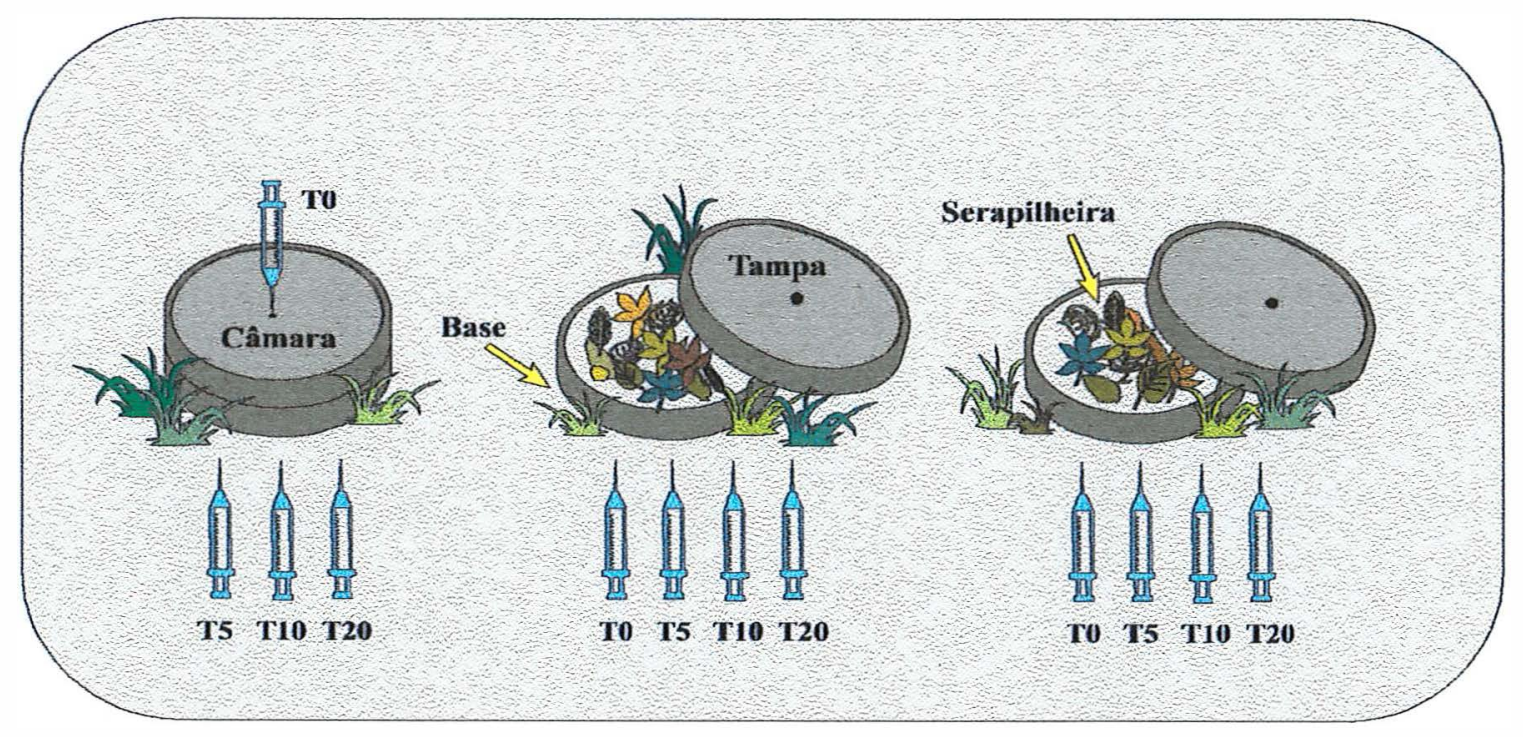

Figura 7a - Esquema das câmaras para coleta de gás

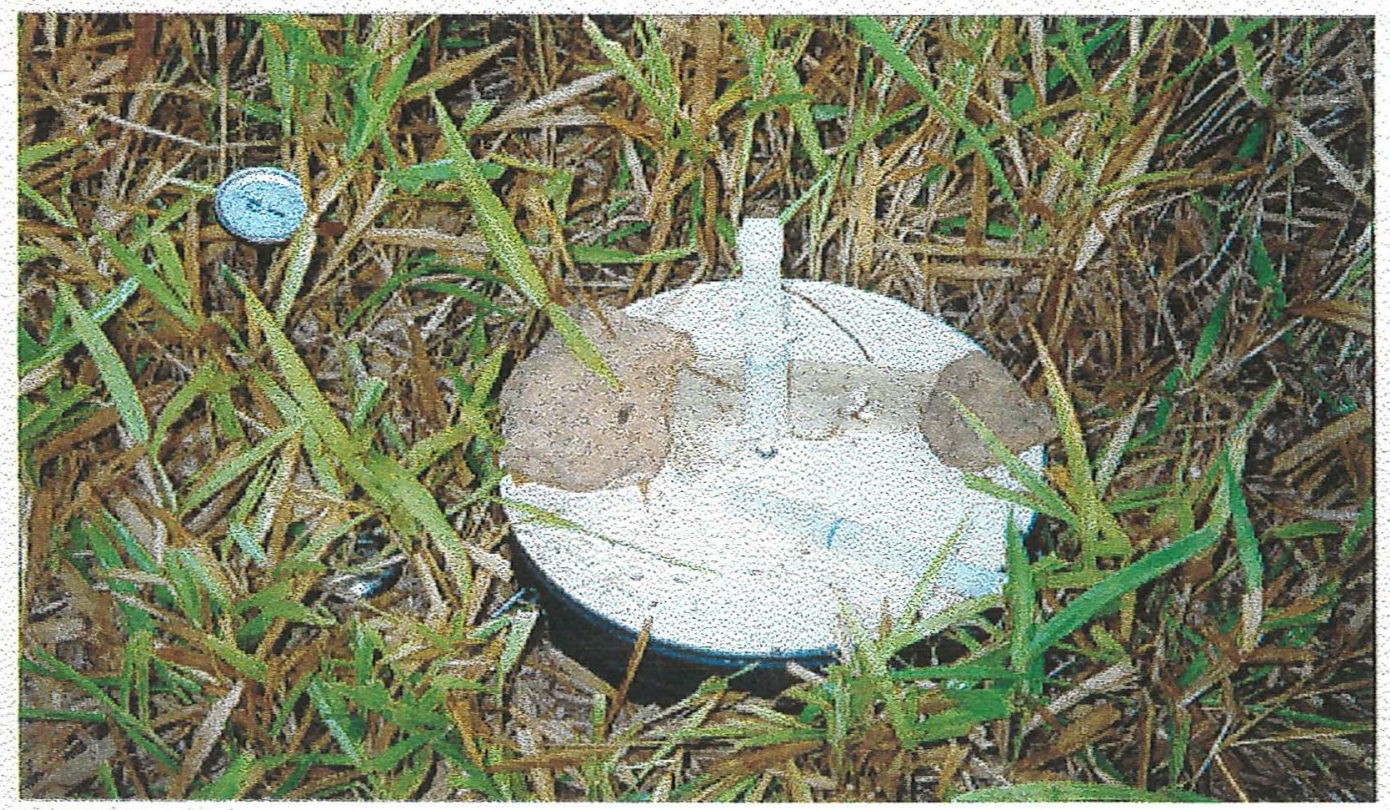

Figura 7b - Foto da câmara de coleta de gás durante coleta numa área de pastagem

centímetros de abertura interna, foi enterrada dois centímetros no solo e fixada por três ganchos para uma maior sustentação; em seguida foi colocada sobre a base, a tampa da câmara, que possui o mesmo tamanho desta, a diferença é que a tampa possui uma altura interna de quatro centímetros e um orificio por onde é coletado o gás, esse orificio, a cada coleta, é aberto e posteriormente fechado por um dispositivo tipo torneira. 
Os horários das coletas foram às 7 horas, 12 horas e às 17 horas. Esses horários se justificam, por se tratarem, teoricamente, dos horários cujas temperaturas seriam, a mais baixa, a mais alta e a intermediária entre as duas primeiras.

A cada horário de coleta foram medidas as temperaturas no interior da câmara, as temperaturas ambiente, e nas profundidades de $2 \mathrm{~cm}, 5 \mathrm{~cm}$ e $10 \mathrm{~cm}$ do solo, no início e no final das coletas.

A retirada dos gases do interior das câmaras foi feita por seringas próprias para este tipo de coleta, em cada seringa foram retirados cerca de $20 \mathrm{~cm}^{3}$ de gás, cada seringa foi devidamente identificada quanto à câmara e o horário da coleta, bem como a área a ser coletada.

Após a coleta dos gases, as seringas foram fechadas por dispositivo próprio tipo torneira, e presas com elásticos o dispositivo de fechamento com o embolo, para evitar contaminação com gases externos.

As seringas foram levadas para o laboratório de Química do Solo do CENA, onde foram analisadas as presenças dos gases $\mathrm{CO}_{2}, \mathrm{~N}_{2} \mathrm{O}$ e $\mathrm{CH}_{4}$, em cromatógrafo da marca Shimadzu, modelo CR 501.

\subsection{Preparação das amostras de solo}

As amostras de solo foram acondicionadas em sacos plásticos com respiros, e enviadas ao laboratório de Química do Solo do CENA, no laboratório foram peneiradas para a retirada das raízes.

De cada amostra retirou-se uma sub-amostra de cerca de $200 \mathrm{~g}$ para a análise de carbono e nitrogênio total. Essas sub-amostras foram secas ao ar, peneiradas a $2 \mathrm{~mm}$, obtendo-se desta maneira a terra fina seca ao ar (TFSA), moídas e peneiradas a 100 meshes. O restante foi guardado em câmara fria para a determinação da biomassa microbiana.

As amostras que foram utilizadas para a determinação da estabilidade estrutural, foram coletadas em bandejas, a fim de evitar ao máximo a destruição da estrutura do solo, e analisadas no Laboratório de Solos do Departamento de Água e Solo da Faculdade de Engenharia Agrícola - UNICAMP. 


\subsection{Análises químicas do solo}

- pH: foi determinado em água e em $\mathrm{KCl}$, utilizando-se uma relação 2,5:1 solo-líquido. Submeteu-se a suspensão obtida a agitação durante cinco minutos em agitador mecânico, com o objetivo de atingir o equilíbrio iônico, em seguida fez-se a leitura. A medida do $\mathrm{pH}$ foi obtida diretamente da escala graduada do aparelho medidor de $\mathrm{pH}$, marca digimed, modelo DMPH-2 (Embrapa 1979).

- Acidez trocável $(\mathbf{H}+\mathbf{A l})$ : foram extraídos por $\mathrm{HCl} 1 \mathrm{~N}$ e dosados por titulação com $\mathrm{NaOH} 0,025 \mathrm{~N}$. O alumínio foi determinado, por titulação do extrato com $\mathrm{HCl} 0,025 \mathrm{~N}$, após neutralização e adição de fluoreto de sódio $4 \%$. O hidrogênio foi determinado por diferença. Pesou-se $5 \mathrm{~g}$ de solo seco e adicionou-se $50 \mathrm{ml}$ de solução de $\mathrm{KCl} 1 \mathrm{~mol} / \mathrm{l}$ e agitou-se durante quinze minutos em agitador mecânico. Procedeu-se a filtração e pipetou-se $25 \mathrm{ml}$ de extrato, que foi titulado com solução de $\mathrm{NaOH} 0,025 \mathrm{~mol} / \mathrm{l}$ utilizando fenolftaleína $0,5 \%$ como indicador. Adicionou-se uma gota de $\mathrm{HCl} 0,025 \mathrm{~mol} / \mathrm{l}$ à solução titulada e $2 \mathrm{ml}$ de solução de $\mathrm{NaF}$ a $4 \%$. Em seguida procedeu-se à titulação com $\mathrm{HCl}$ $0,025 \mathrm{~mol} / \mathrm{l}$. Os miliequivalentes de ácido utilizados foram considerados correspondentes a miliequivalentes de $\mathrm{Al}$ trocável por $100 \mathrm{~cm}^{3}$ de solo e os resultados expressos em $\mathrm{mmol}_{\mathrm{c}}$ $\mathrm{dm}^{-3}$ (Anderson, 1989).

- CTC: Cálcio, magnésio, potássio e sódio serão extraídos com $\mathrm{HCl}$ 0,05 N, e o cálcio e o magnésio foi determinado por espectrofotometria de absorção atômica e sódio e potássio por fotometria de chama (Anderson, 1989). 


\subsection{Análises físicas do solo}

- A densidade do solo foi determinada através do método do cilindro volumétrico de Embrapa (1979), onde as amostras de solo coletadas na parede do perfil do solo, por cilindros de $52,48 \mathrm{~cm}^{3}$ foram secas à $105^{\circ} \mathrm{C}$ e em seguida pesadas. A densidade foi calculada pela fórmula:

Densidade $\left(\mathrm{g} / \mathrm{cm}^{3}\right)=$ massa do solo $\left(105^{0} \mathrm{C}\right) /$ volume do cilindro

- Análises granulométricas do solo foram realizadas na ESALQ, no Departamento de Ciência do Solo, através do método do densímetro. Consiste em dispersar a amostra de solo em agitador elétrico de 1200 RPM, em seguida transferir a amostra para um cilindro de sedimentação. Após a suspensão ter sido homogeneizada por um minuto, efetuou-se a leitura da densidade com hidrômetro a vários intervalos de tempo, conforme o método descrito no Manual de Métodos de Análises de Solo (Embrapa 1979). Os resultados foram convertidos em porcentagem de argila de acordo com os valores tabelados e posteriormente convertidos em gramas por quilograma $\left(\mathrm{g} \mathrm{kg}^{-1}\right)$.

\section{- Estabilidade estrutural:}

A estabilidade dos agregados foi medida através do seu diâmetro médio ponderado (DMP) em 3 condições: embebidos em água, benzeno e álcool, conforme o método descrito em Camargo et al. (1986).

Esta análise baseia-se no princípio de que o umidecimento de uma amostra causa uma expansibilidade diferencial interna, provocando ruptura nos locais de união menos intensa entre as partículas.

As amostras foram passadas por peneiras de 7 e $2 \mathrm{~mm}$. Da fração retida entre as peneiras foram pesados $20 \mathrm{~g}$, colocados em um béquer e adicionada água para um total umidecimento. Esperados 5 minutos, foram despejados $200 \mathrm{ml}$ de água e a amostra foi colocada para agitar por $30 \mathrm{~min}$. a $40 \mathrm{rpm}$, em água no topo de um jogo de peneiras com malha de 4,$0 ; 2,0 ; 1,0 ; 0,5 ; 0,25$ e $0,105 \mathrm{~mm}$. Foram obtidos, então, agregados com diâmetros entre 6,35 e $2 \mathrm{~mm} ; 2,00$ e $1,00 \mathrm{~mm} ; 1,00$ e $0,50 \mathrm{~mm} ; 0,25$ e $0,125 \mathrm{~mm}$ e 
menores que $0,125 \mathrm{~mm}$. O conteúdo de cada peneira foi seco a $105^{\circ} \mathrm{C}$ e então pesado. A fração que passa pela última peneira é obtida por diferença.

No caso da avaliação da influência dos cátions na estabilidade dos agregados foram adicionados $20 \mathrm{ml}$ de álcool à fração retida entre as peneiras de 7 e $2 \mathrm{~mm}$, e após 5min. foram adicionados $200 \mathrm{ml}$ de água, seguindo-se agitação. Para a avaliação da influência da matéria orgânica o álcool foi substituído por benzeno.

O índice de estabilidade em água, álcool e benzeno foi obtido da seguinte forma:

$$
\mathrm{CC} \times \mathrm{Pi}=\mathrm{X} \text {, para cada peneira }
$$

onde:

$\mathrm{CC}$ : centro de classe ou diâmetro médio do agregado retido entre duas peneiras $(4,2,1,0,5,0,25,0,105 \mathrm{~mm})$

Pi: peso da fração que ficou na peneira

O índice de Estabilidade é obtido pela expressão:

$$
\sum X i=\left(X_{4}+X_{2}+X_{1}+X_{0,5}+X_{0,25}+X_{0,105}\right)
$$

\subsection{Determinação do estoque de carbono total}

A determinação do carbono orgânico total, foi realizada na Seção de Química do Solo do CENA.

Amostras previamente preparadas, foram submetidas a combustão a seco, a $1100^{\circ} \mathrm{C}$ sob fluxo de oxigênio utilizando-se o equipamento LECO CR - 412. O gás $\mathrm{CO}_{2}$ produzido foi absorvido em uma solução contendo $\mathrm{NaOH} 0,05 \mathrm{~mol} / \mathrm{l}$. A diferença na condutividade elétrica entre a solução de $\mathrm{NaOH}$ de referência e a carbonatada $\operatorname{com} \mathrm{CO}_{2}$ da amostra foi detectada e registrada diretamente em $\mathrm{mg}$ de carbono. O resultado foi expresso em porcentagem de carbono.

$\mathrm{O}$ conteúdo total de carbono foi convertido em $\mathrm{t} / \mathrm{ha}$, multiplicando-se os teores de carbono pela densidade do solo e espessura da camada. 


\subsection{Nitrogênio total}

Nesta determinação foi adotada uma adaptação do método micro-Kjeldahl comumente utilizado na seção de Química do Solo - CENA/USP, que envolve o uso de uma solução digestora à base de $\mathrm{H}_{2} \mathrm{O}_{2}(1000 \mathrm{ml}), \mathrm{H}_{2} \mathrm{SO}_{4}(1200 \mathrm{ml})$, Se $(1,2 \mathrm{~g})$ e $\mathrm{LiSO}_{4}$ $(40 \mathrm{~g})$, com a digestão sendo feita a $320^{\circ} \mathrm{C}$ por 4 horas, e posterior destilação a vapor e titulação do destilado, que foi recolhido em $10 \mathrm{ml}$ de solução de $\mathrm{H}_{3} \mathrm{BO}_{3}(2 \%)$, misturada com uma solução de verde de bromocresol e vermelho de metila, a titulação foi feita com $\mathrm{H}_{2} \mathrm{SO}_{4}(0,1 \mathrm{~N})$.

O conteúdo de nitrogênio em t/ha foi calculado através da multiplicação dos teores de nitrogênio pela densidade do solo e espessura da camada.

\subsection{Fracionamento da matéria orgânica}

Foi utilizado o método proposto por Dabin (1971), com modificações, utilizado na Seção de Química do Solo - CENA/USP.

Esse método consta de uma extração inicial feita com água, sendo a solução obtida filtrada em lã de vidro, separando-se duas frações: a matéria orgânica leve, retida na lã de vidro, e compostos hidrossolúveis no extrato. Após esse passo, seguiu-se um tratamento com $\mathrm{H}_{3} \mathrm{PO}_{4}(2 \mathrm{M})$, para eliminar os cátions que fixam o húmus sobre a argila. Nesse pré-tratamento foram extraídos os ácidos fúlvicos livres.

O solo residual foi lavado com água, sofrendo em seguida extrações sucessivas em $\mathrm{Na}_{4} \mathrm{P}_{2} \mathrm{O}_{7}(0,1 \mathrm{M})$ e $\mathrm{NaOH}(0,1 \mathrm{~N})$, obtendo-se assim os ácidos fúlvico e húmico, nos extratos, e a humina no resíduo. A separação entre ácido húmico e fúlvico se faz com a acidificação do extrato e centrifugação, permanecendo o ácido fúlvico em solução, enquanto que o ácido húmico flocula e se deposita no fundo do tubo da centrífuga. 


\subsection{Relação ${ }^{13} \mathrm{C} /{ }^{12} \mathrm{C}\left(\delta^{13} \mathrm{C}\right)$}

A análise da relação ${ }^{13} \mathrm{C} /{ }^{12} \mathrm{C}$, foi feita nas cinco primeiras profundidades das amostras coletadas na trincheira. Foi utilizado o método dinâmico para a transformação do carbono orgânico em $\mathrm{CO}_{2}$, que consiste na combustão da amostra em fluxo contínuo de $\mathrm{O}_{2}$ puro sobre pressão positiva, com a amostra gasosa sendo analisada em espectrômetro de massa, marca Micromass $602 \mathrm{E}$. A relação ${ }^{13} \mathrm{C} /{ }^{12} \mathrm{C}$ da amostra expressa na forma de $\delta$ por mil $(\% 0)$, com relação ao padrão internacional PDB, assim definido:

$$
\delta^{13} \mathrm{C}=(\mathrm{R} \text { amostra }-\mathrm{R} \text { padrão }) / \mathrm{R} \text { padrão }
$$

onde: $\mathrm{R}$ amostra $=$ relação ${ }^{13} \mathrm{C} /{ }^{12} \mathrm{C}$ da amostra

$$
\mathrm{R} \text { padrão }=\text { relação }{ }^{13} \mathrm{C} /{ }^{12} \mathrm{C} \text { do padrão }
$$

As porcentagens de carbono derivado da vegetação nativa $(\mathrm{Cf})$ e da pastagem (Dp) foram obtidas através das equações:

$$
\begin{gathered}
C_{p}=\frac{\delta-\delta_{0}}{\delta c-\delta_{0}} \times \% C t \\
C f=\% C t-C p
\end{gathered}
$$

onde: $\delta=\delta^{13} \mathrm{C}$ do solo sob pastagem

$$
\begin{aligned}
& \delta_{0}=\delta^{13} \mathrm{C} \text { do solo sob floresta } \\
& \delta \mathrm{c}=\delta^{13} \mathrm{C} \text { do material vegetal (gramínea) } \\
& \% \mathrm{Ct}=\% \text { carbono total do solo sob pastagem }
\end{aligned}
$$




\subsection{Estimativa da biomassa microbiana C pelo método da Fumigação- Extração}

O método da Fumigação-Extração (Vance et al.,1987) foi utilizado para a determinação da biomassa microbiana $\mathrm{C}$.

As amostras de solo, fumigadas e testemunhas, correspondendo a $25 \mathrm{~g}$ de solo seco, foram transferidas a erlenmeyer de $250 \mathrm{ml}$ adicionando-se $100 \mathrm{ml}$ de $\mathrm{K}_{2} \mathrm{SO}_{4}(0,5 \mathrm{M})$. O conjunto foi agitado por 1 hora e a suspensão resultante filtrada em papel de filtro.

O carbono orgânico foi determinado pela digestão de $8 \mathrm{ml}$ do extrato filtrado com $2 \mathrm{ml}$ de $\mathrm{K}_{2} \mathrm{Cr}_{2} \mathrm{O}_{7}$, $(66,7 \mathrm{mM}), 10 \mathrm{ml}$ de $\mathrm{H}_{2} \mathrm{SO}_{4}$ concentrado e $5 \mathrm{ml}$ de $\mathrm{H}_{3} \mathrm{PO}_{4}$ concentrado, durante 1 hora. O excesso de dicromato foi determinado por titulação com Sulfato Ferroso de Amônio $(33,3 \mathrm{mM})$ em $\mathrm{H}_{2} \mathrm{SO}_{4}(0,4 \mathrm{M})$ usando-se fenantrolina como indicador.

$\mathrm{O}$ carbono extraível é calculado assumindo que $1 \mathrm{ml} \mathrm{de} \mathrm{K}_{2} \mathrm{Cr}_{2} \mathrm{O}_{7} \quad(66,7 \mathrm{mM})$ é equivalente a $1200 \mu \mathrm{gC}$.

Para a biomassa microbiana o cálculo foi feito pela seguinte relação:

$$
\text { Biomassa } \mathrm{C}=\mathrm{EC} / \mathrm{K}_{\mathrm{ci}}
$$

onde $: \mathrm{EC}=$ diferença entre o carbono extraído dos tratamentos fumigados e testemunho, expressos em $\mu \mathrm{gC} / \mathrm{g}$ solo.

$$
\mathrm{K}_{\mathrm{ci}}=\text { coeficiente de mineralização }=0,38 \text {. }
$$

\subsection{Estimativa da biomassa microbiana N pelo método da Fumigação-Extração}

A biomassa microbiana $\mathrm{N}$ foi quantificada pelo método da Fumigação-Extração de Brookes et al. (1985), onde o $\mathrm{N}$ contido no extrato, extraído com $\mathrm{K}_{2} \mathrm{SO}_{4}(0,5 \mathrm{M})$, nas amostras fumigadas e testemunhas é determinado através do método de digestão microKjeldahl. O coeficiente de mineralização $\left(\mathrm{K}_{\mathrm{n}}\right)$ usado no cálculo da biomassa $\mathrm{N}$ foi de 0,54 . 


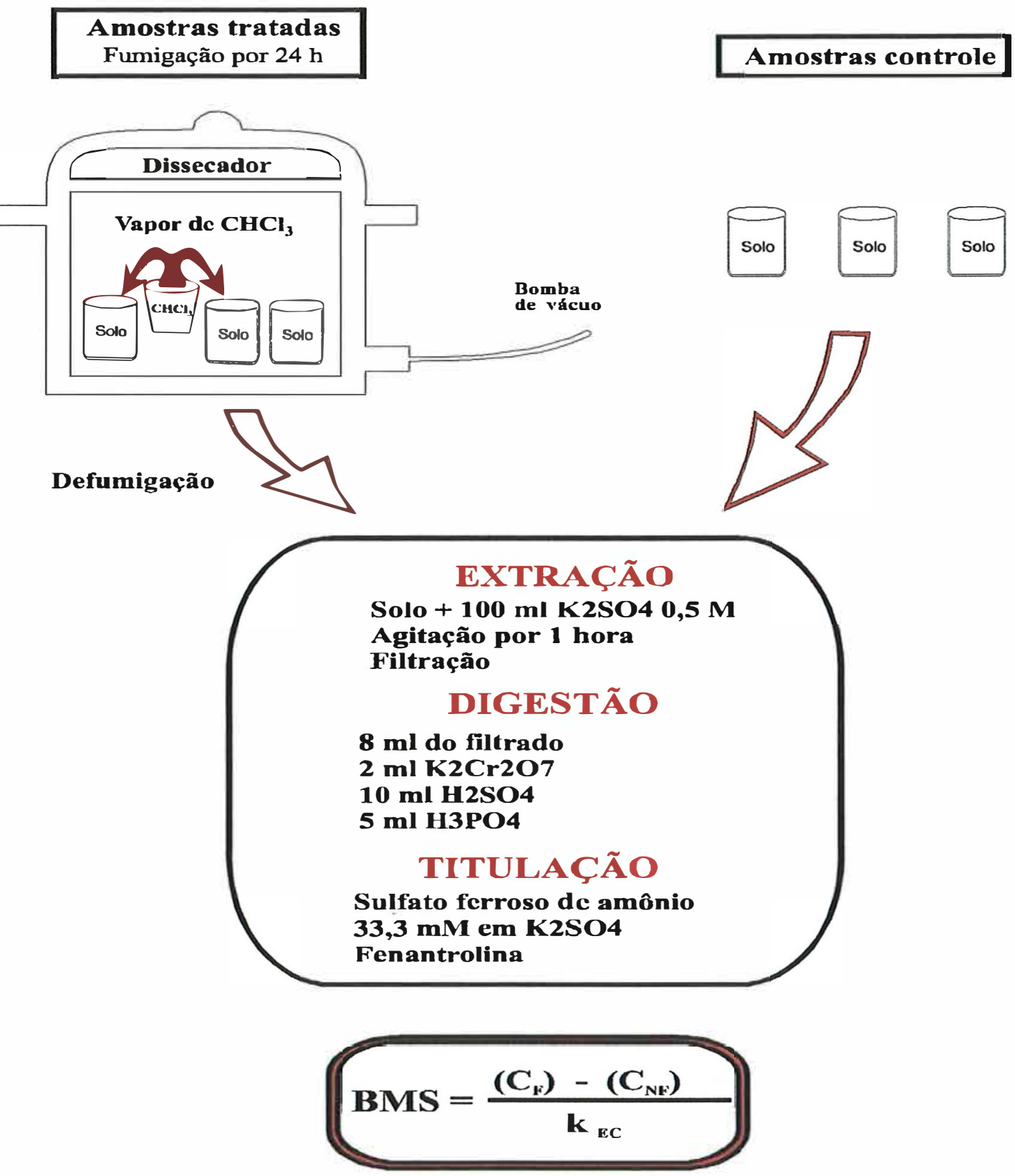

Figura 8 - Esquema do método da fumigação-extração para determinação da biomassa microbiana. Vance et al. (1987). 


\section{RESULTADOS E DISCUSSÃO}

Inicialmente serão apresentadas e discutidas a evolução das características físicas e químicas do solo. Em seguida, serão tratados os itens referentes à alteração na natureza e dinâmica da matéria orgânica do solo.

\subsection{Características físicas e físico-químicas do solo}

Nesse tópico serão apresentados e discutidos os resultados analíticos referentes às características granulométricas, $\mathrm{pH}$, acidez trocável e densidade do solo cultivado e sob mata nativa.

\subsubsection{Características granulométricas}

Os dados granulométricos dos solos utilizados estão apresentados na Tabela 2. Pode-se notar que o solo em estudo nas quatro áreas, está incluído na categoria de textural arenosa, com os valores da fração areia em torno de $880 \mathrm{~g} \mathrm{~kg}^{-1} \mathrm{e}$ com valores da fração argila próximos a $80 \mathrm{~g} \mathrm{~kg}^{-1}$ e de silte cerca de $40 \mathrm{~g} \mathrm{~kg}^{-1}$.

A figura 9 e a tabela 2 demonstram claramente que sob o ponto vista granulométrico, as três áreas cultivadas e a mata natural estão situadas sob a mesma família de solo. 
Tabela 2. Características físicas e físico-químicas do solo sob mata natural e cultivados. (Prof. = profundidade; $\mathrm{ag}=$ argila; $\mathrm{si}=$ silte; ar = areia; $\mathrm{d}$ = densidade; $\mathrm{Al}^{+3}+\mathrm{H}=$ acidez; $\mathrm{S}$ = soma de bases; $\mathrm{CTC}=$ capacidade de troca catiônica; $\mathrm{V}=$ saturação de bases).

\begin{tabular}{|c|c|c|c|c|c|c|c|c|c|c|c|c|c|}
\hline \multirow{3}{*}{$\frac{\text { Prof. }}{\mathrm{cm}}$} & \multirow{3}{*}{ ag } & \multirow{3}{*}{$\frac{\mathrm{si}}{\mathrm{g} \mathrm{kg}^{-1}}$} & \multirow{3}{*}{ ar } & \multirow{3}{*}{$\frac{\mathrm{d}}{\mathrm{g} \mathrm{cm}^{-3}}$} & \multirow[t]{3}{*}{ pH } & \multirow[t]{2}{*}{$\mathrm{Ca}^{2+}$} & \multirow[t]{2}{*}{$\mathrm{Mg}^{2}$} & \multirow[t]{2}{*}{$\mathbf{K}^{+}$} & \multicolumn{2}{|c|}{$\mathrm{Na}^{+} \mathrm{Al}^{3+}+\mathrm{H}$} & \multirow[t]{2}{*}{$\mathbf{S}$} & \multirow[t]{2}{*}{ CTC } & \multirow{3}{*}{$\begin{array}{l}\mathrm{V} \\
\%\end{array}$} \\
\hline & & & & & & & & & \multirow{2}{*}{\multicolumn{2}{|c|}{$\mathrm{mmol}_{\mathrm{c}} \mathrm{kg}^{-1}$}} & & & \\
\hline & & & & & & & & & & & & & \\
\hline $0-$ & 80,0 & 40,0 & 8 & & 3,6 & 8,0 & 15,6 & 0,8 & & 17,5 & 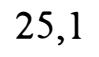 & 6 & 58 \\
\hline $5-$ & 40,0 & 40,0 & 920,0 & 1, & 40 & 6,0 & 9,9 & 0,7 & & 11 & 17 & 29,4 & 60 \\
\hline $0-2$ & 60,0 & 40,0 & 90 & 1,22 & 4,1 & 4,0 & 4 & 0,2 & & 9 & 8,9 & 18,5 & 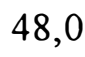 \\
\hline $0-3$ & 60,0 & 60,0 & 880,0 & 1,24 & 4,0 & 3,0 & 4,1 & 0,2 & 0 & 8,3 & 8 , & 16,3 & 49 \\
\hline $0-40$ & 0,0 & 40,0 & 900,0 & 1,26 & 4,1 & 10,9 & 4,1 & 0,2 & 0,6 & 7,3 & 15,9 & 23,2 & 68 \\
\hline
\end{tabular}

\section{Pastagem}

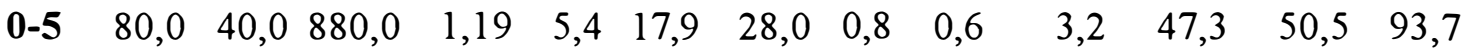

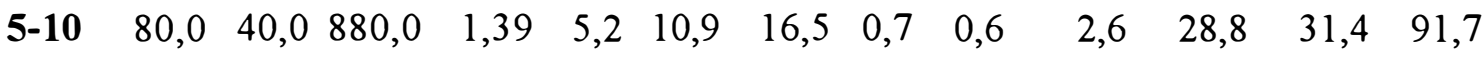

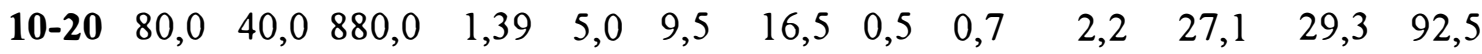

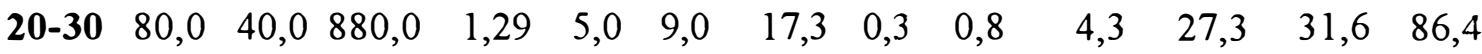

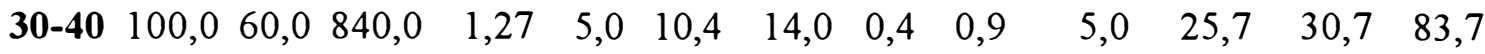

\section{Cana-de-açúcar}

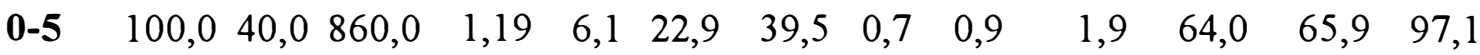

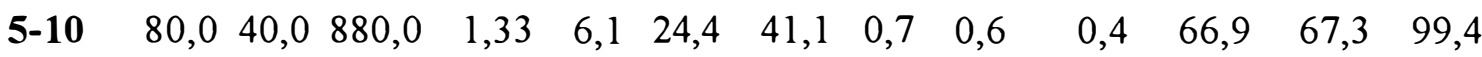

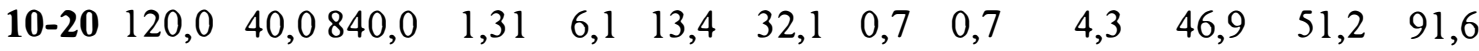

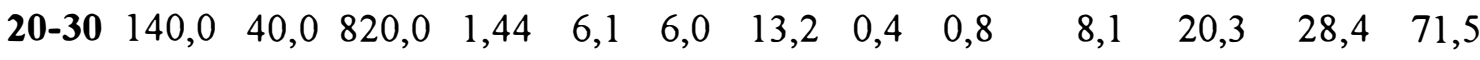

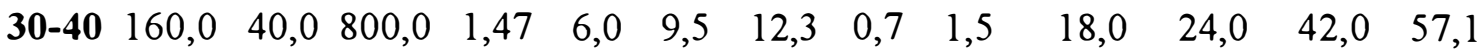

\section{Eucalipto}

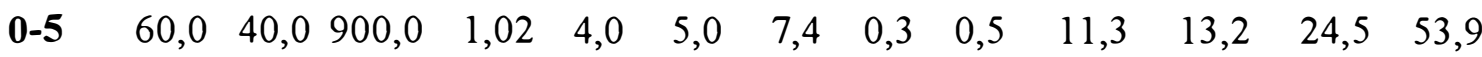

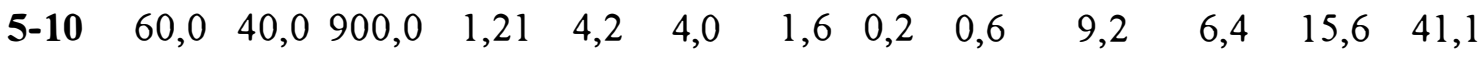

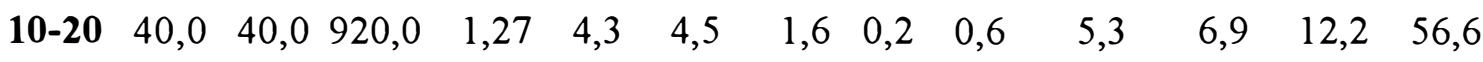

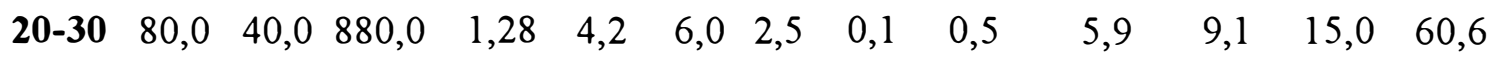

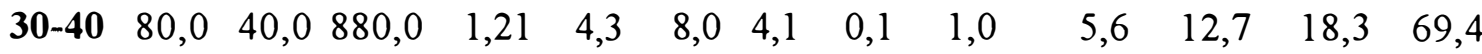




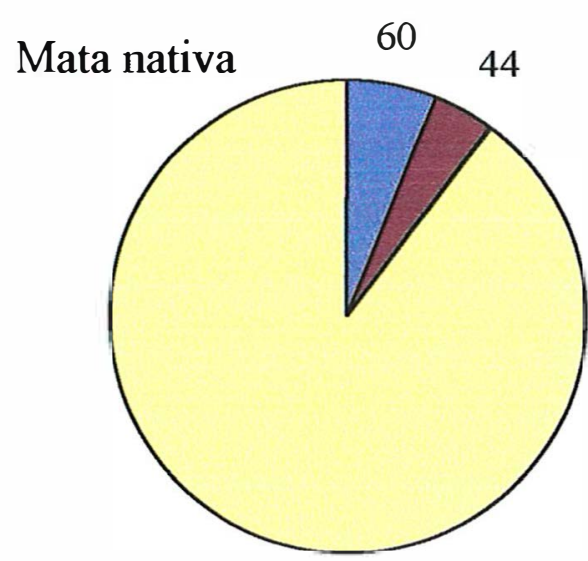

896

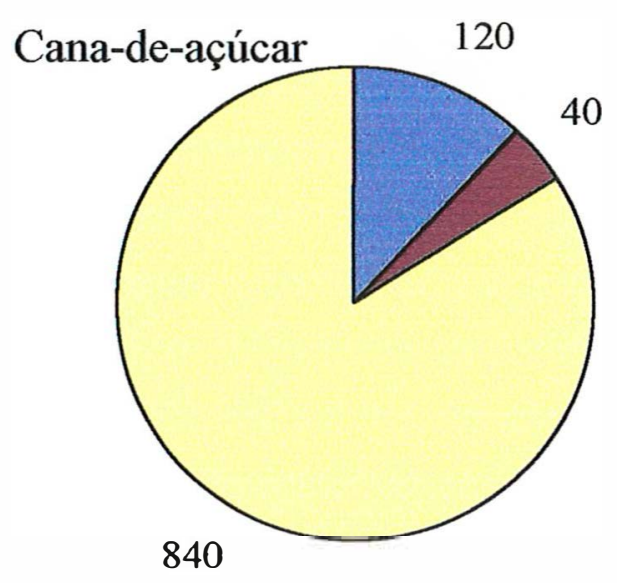

Argila

Silte

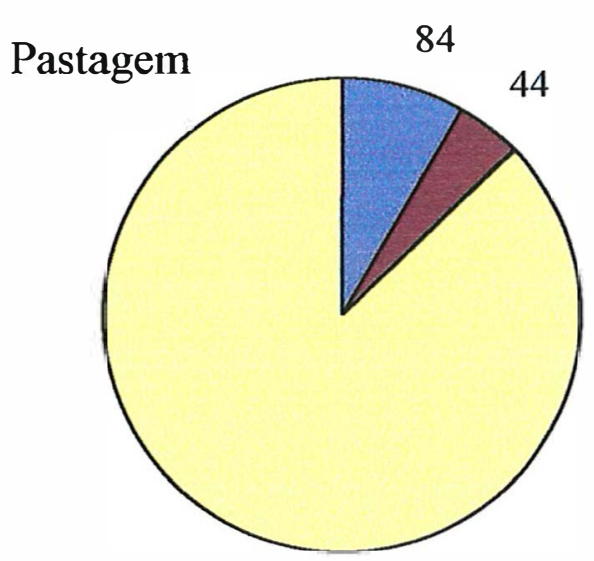

872

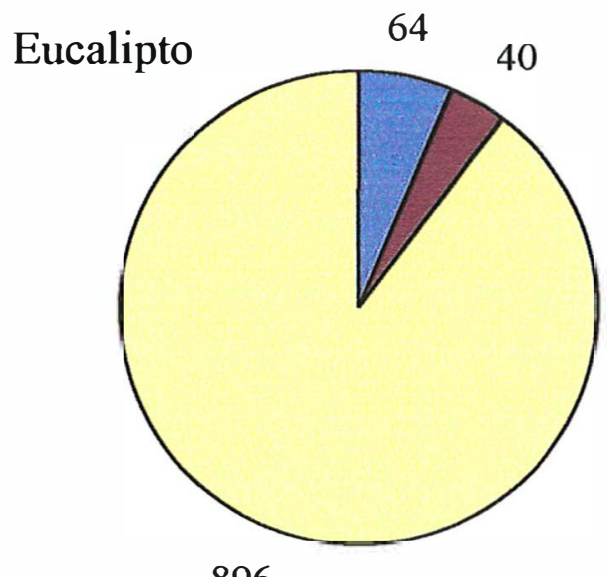

896

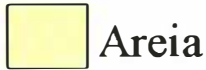

Figura 9 - Distribuição granulométrica dos solos sob as culturas estudadas

\subsubsection{Densidade}

$\mathrm{Na}$ área com mata, os valores aumentaram gradativamente de $0,95 \mathrm{~g} \mathrm{~cm}^{-3}$ a 1,26 $\mathrm{g} \mathrm{cm}^{-3}$, entre a camada mais superficial $(0-5 \mathrm{~cm})$ até a camada $30-40 \mathrm{~cm}$.

Os primeiros vinte centímetros do solo pastagem apresentam valores de densidade superiores às camadas subsequentes. Observa-se densidade de $1,39 \mathrm{~g} \mathrm{~cm}^{-3} \mathrm{a}$ vinte centímetros de profundidade e uma diminuição a $1,27 \mathrm{~g} \mathrm{~cm}^{-3}$ na camada $30-40 \mathrm{~cm}$. Este fato pode estar relacionado ao pisoteio do gado que mesmo não sendo muito intenso contribui para um aumento da densidade. 
$\mathrm{Na}$ área com cana-de-açúcar a densidade é mais elevada ém todas as profundidades. Na camada mais superficial $(0-5 \mathrm{~cm})$ o valor encontrado foi de $1,19 \mathrm{~g} \mathrm{~cm}^{-3}$ enquanto que na mais profunda $(30-40 \mathrm{~cm})$ atingiu $1,47 \mathrm{~g} \mathrm{~cm}^{-3}$. $\mathrm{O}$ manejo anual do solo deve ser o fator que mais contribuiu para o aumento da densidade, para este preparo, são utilizados tratores e implementos agrícolas que afetam a estruturação do solo.

$\mathrm{Na}$ área com eucalipto a densidade variou entre $1,02 \mathrm{~g} \mathrm{~cm}^{-3}(0-5 \mathrm{~cm})$ e $1,21 \mathrm{~g}$ $\mathrm{cm}^{-3}(30-40 \mathrm{~cm})$. Esses valores são os que mais se aproximam aos da área com mata.

A densidade aumentou com a profundidade, exceção feita a área com pastagem, que teve um incremento até a camada $10-20 \mathrm{~cm}$, diminuindo em seguida.

Nas áreas utilizadas com pastagem e cana-de-açúcar a densidade foi maior em relação a área com mata nativa; já sob eucalipto os valores encontrados se aproximaram mais daqueles da mata nativa.

Nas áreas com eucalipto e mata, o aumento da densidade com a profundidade foi o esperado. Segundo Kiehl (1979), a densidade do solo geralmente aumenta com a profundidade, pois as pressões exercidas pelas camadas superiores sobre as subjacentes favorecem a compactação natural. Além disso o movimento de material fino dos horizontes superiores para os inferiores reduz os espaços porosos, aumentando a densidade.

A mudança do uso da terra, alterou a densidade em relação a mata nativa, principalmente na área com cana-de-açúcar, que devido ao manejo anual do solo, apresenta valores de densidade maiores na camada arável.

$\mathrm{O}$ aumento da densidade do solo com o cultivo foi demonstrado por Cerri et al (1991), Geraldes (1993) e Fernandes (1993). O uso de máquinas agrícolas conduz a um aumento da densidade do solo( Chauvel et al, 1991).

Quanto maior a densidade, maior a compactação do solo e, certamente o sistema radicular terá dificuldades para se desenvolver. Portanto, práticas de manejo devem ser adotadas com a finalidade de diminuir a densidade nos horizontes superficiais, a fim de favorecer o desenvolvimento das plantas. 


\subsubsection{Estabilidade dos agregados}

A estabilidade dos agregados é medida de acordo com o diâmetro médio ponderado (DMP) em milímetros. O tratamento com álcool demonstra a influência dos cátions trocáveis, enquanto que com benzeno relaciona a importância da matéria orgânica na agregação do solo Camargo et al. (1986).

Analisando os valores apresentados na tabela 3, pode-se notar que o grau de estabilidade é muito baixo, o que já era esperado, por se tratar de solo com textura arenosa.

Essa análise deve ser considerada como exploratória, uma vez que não foram feitas repetições necessárias. Mesmo assim, os resultados obtidos indicam uma tendência quanto à estabilidade dos agregados que confirmam as expectativas.

A agregação no caso da mata deve-se principalmente ao maior teor de matéria orgânica e a grande quantidade de raízes existentes no sistema. É possível notar que a diminuição da agregação ao longo do perfil segue a mesma característica apresentada para a diminuição da matéria orgânica.

$\mathrm{Na}$ área com pastagem, a agregação também é devido à matéria orgânica, principalmente nas camadas mais superficiais, onde a quantidade de raízes é elevada e há uma grande liberação de exsudados que contribuem para a agregação do solo e também está ligada, em menor importância, aos cátions trocáveis.

A agregação na área com cana-de-açúcar, apresenta comportamento diferente das demais áreas. A estabilidade praticamente não varia dentro do perfil. A menor quantidade de matéria orgânica no sistema parece ser o fator mais importante que contribui na baixa agregação apresentada nesta área.

A quantidade de cátions trocáveis mais elevado nesta área que nas demais, não foi suficiente para proporcionar ao solo uma agregação maior. Por outro lado o manejo anual do solo para o plantio ocasiona uma destruição dos agregados do solo. 
Tabela 3. Diâmetro Médio Ponderado (DMP) avaliado em água, álcool e benzeno, sob efeito das diversas coberturas do solo.

\begin{tabular}{|c|c|c|c|}
\hline \multicolumn{4}{|c|}{ Diâmetro Médio Ponderado (mm) } \\
\hline \multicolumn{4}{|c|}{ Extrações } \\
\hline Prof. & Água & Álcool & Benzeno \\
\hline $\mathbf{c m}$ & \multicolumn{3}{|c|}{ Mata } \\
\hline $0-5$ & 2,37 & 2,21 & 1,65 \\
\hline $5-10$ & 0,70 & 0,77 & 1,92 \\
\hline $10-20$ & 1,03 & 0,68 & 1,63 \\
\hline $20-30$ & 0,88 & 0,48 & 0,65 \\
\hline $30-40$ & 1,08 & 0,97 & 1,66 \\
\hline \multicolumn{4}{|c|}{ Pastagem } \\
\hline $0-5$ & 0,96 & 0,77 & 0,72 \\
\hline $5-10$ & 1,23 & 0,35 & 0,31 \\
\hline $10-20$ & 0,44 & 0,60 & 0,57 \\
\hline $20-30$ & 1,46 & 1,48 & 1,96 \\
\hline $30-40$ & 0,56 & 0,20 & 0,34 \\
\hline \multicolumn{4}{|c|}{ Cana-de-açúcar } \\
\hline $0-5$ & 0,31 & 0,20 & 0,19 \\
\hline $5-10$ & 0,21 & 0,21 & 0,14 \\
\hline $10-20$ & 0,19 & 0,17 & 0,22 \\
\hline $20-30$ & 0,18 & 0,20 & 0,20 \\
\hline $30-40$ & 0,19 & 0,15 & 0,17 \\
\hline \multicolumn{4}{|c|}{ Eucalipto } \\
\hline $0-5$ & 1,29 & 0,87 & 0,85 \\
\hline $5-10$ & 1,29 & 0,76 & 1,10 \\
\hline $10-20$ & 2,16 & 1,03 & 1,24 \\
\hline $20-30$ & 0,56 & 0,42 & 0,60 \\
\hline $30-40$ & 0,90 & 1,03 & 0,66 \\
\hline
\end{tabular}


Nesse caso, tanto a matéria orgânica como os cátions trocáveis tiveram grau semelhante de importância para a agregação, visto que os valores encontrados para a análise em benzeno e álcool se equivalem.

$\mathrm{Na}$ área com eucalipto o fator que provavelmente mais contribui para a agregação são os cátions trocáveis existentes no sistema, e a matéria orgânica proveniente do material que é depositado pela decomposição, sugerindo que estes dois fatores são complementares.

Analisando o DMP dos agregados determinado em água, álcool e benzeno, observa-se que os solos que apresentam maior estabilidade são respectivamente aqueles sob mata nativa, eucalipto, pastagem e, por último, sob cana-de-açúcar.

Esses valores confirmam o esperado, de que a matéria orgânica é um fator de agregação, assim como os cátions trocáveis.

Nas áreas com cana-de-açúcar e pastagem, principalmente a primeira que passa por manejo anual do solo, e a pastagem, que na maior parte do ano não apresenta uma eficiente cobertura no solo, ficam mais sujeitas aos agentes climáticos desagregadores da estrutura do solo. conseqüentemente a estabilidade dos agregados é maior nas áreas com mata nativa e eucalipto, nas quais os impactos devido às chuvas são minimizados.

\subsection{4 pH}

Os valores de $\mathrm{pH}$ encontrados para área com a mata nativa, não variam significativamente nas duas primeiras camadas, porém, houve uma ligeira tendência de aumento do $\mathrm{pH}$ nas camadas mais profundas. Observa-se uma diferença estatisticamente significativa (Tukey, $\mathrm{p}<0,05$ ) nas camadas $10-20 \mathrm{~cm}$ e $30-40 \mathrm{~cm}$, onde os valores passaram de 3,6 na camada $0-5 \mathrm{~cm}$ para 4,1 entre $30-40 \mathrm{~cm}$.

$\mathrm{Na}$ área com pastagem, os valores de $\mathrm{pH}$ não demonstraram diferença estatisticamente significativa, variando de $5,4(0-5 \mathrm{~cm})$ até 5,0 na camada $30-40 \mathrm{~cm}$. Em relação à mata, os valores também foram nitidamente mais elevados.

Observa-se que a troca de cultura e conseqüente preparo do solo, condiciona um aumento nos valores de $\mathrm{pH}$, que contudo estão mais próximos aos encontrados nos 
sistemas menos alterados, tendendo, com o tempo, a voltar às condições observadas no sistema nativo (Martins et al., 1990b; Fernandes, 1993).

$\mathrm{Na}$ área com cana-de-açúcar, o $\mathrm{pH}$ não variou significativamente entre as camadas estudadas, Os valores encontrados foram 6,1 na camada 0-5 cm e 6,0 entre 30$40 \mathrm{~cm}$. Em relação à mata nativa os valores de $\mathrm{pH}$ são nitidamente mais elevados. Nesta área o manejo é determinante sobre o $\mathrm{pH}$, pois a cada corte da cana-de-açúcar, é feito o preparo do solo para o ciclo seguinte, e esse processo baseia-se na subsolagem, adubação e calagem (Cerri, 1986). Os valores encontrados são bem superiores aos da área com mata nativa. O maior valor na mata é de 4,1 muito inferior ao menor encontrado para a canade-açúcar que registra valores próximos a 6,0.

$\mathrm{Na}$ área com eucalipto nota-se uma tendência para o aumento do $\mathrm{pH}$ em profundidade do solo. Dentro do perfil não houve diferença significativa entre as profundidades, mas os valores indicam a tendência, passando de 4,0 na camada $0-5 \mathrm{~cm}$ para 4,3 na camada $30-40 \mathrm{~cm}$.

Apesar de os valores de $\mathrm{pH}$ encontrados na área com eucalipto terem sido mais elevados do que os encontrados na mata nativa, não houve diferença estatisticamente significativa entre elas. Esse fato deve-se, provavelmente, ao pouco manejo desta área e também ao longo tempo de uso com esta cultura.

Como pode-se observar, as áreas em estudo apresentam valores de $\mathrm{pH}$ distintos. Nas áreas com culturas agrícolas, os valores de pH são sempre mais elevados, principalmente na cultura da cana-de-açúcar. Os valores mais elevados e mais constantes encontrados nesta área, devem estar ligados a adição de calcário após cada colheita da planta. 


\subsection{Características Químicas}

Neste item serão apresentados e discutidos os valores da acidez trocável e da soma de bases.

\subsubsection{Acidez trocável}

$\mathrm{Na}$ área com mata nativa os valores variam gradativamente. Os mais elevados foram encontrados nas camadas mais superficiais e a medida que aumenta a profundidade esses valores diminuem, passando de $17,5 \mathrm{mmol}_{\mathrm{c}} \mathrm{dm}^{-3}$ de solo na camada de $0-5 \mathrm{~cm}$, para $7,3 \mathrm{mmol}_{\mathrm{c}} \mathrm{dm}^{-3}$ de solo entre $30-40 \mathrm{~cm}$. Portanto uma redução de praticamente duas vezes e meia em relação à camada superficial.

A pastagem apresenta uma tendência de aumento com a profundidade. Variando de 3,2 $\mathrm{mmol}_{\mathrm{c}} \mathrm{dm}^{-3}$ na camada mais superficial, até 5,0 $\mathrm{mmol}_{\mathrm{c}} \mathrm{dm}^{-3}$ de solo, na camada mais profunda, ou seja quase o dobro do valor inicial.

Em relação a mata, na camada mais superficial, a acidez na pastagem é cerca de cinco vezes e meia menor, e na camada mais profunda essa diferença não é tão elevada, apenas uma vez e meia menor que da área com mata.

Pode-se supor também nesse estudo, que o preparo do solo influenciou essa propriedade química, fato que se observa principalmente na área com cana-de-açúcar onde o preparo anual do solo resulta numa acidez mais elevada nas camadas mais profundas.

$\mathrm{Na}$ área com cana-de-açúcar observava-se que o valor mais baixo é de 1,9 $\operatorname{mmol}_{\mathrm{c}} \mathrm{dm}^{-3}$ de solo na camada mais superficial, aumentando para $18,0 \mathrm{mmol}_{\mathrm{c}} \mathrm{dm}^{-3}$ na camada mais profunda. Esses valores evidenciam a mesma tendência observada na pastagem, uma vez que na última camada a acidez é cerca de dez vezes mais elevada que na camada superficial.

Os valores da acidez trocável nas camadas mais superficiais do solo sob canade-açúcar, são inferiores aos encontrados nas demais áreas. Em relação a primeira profundidade da mata nativa o valor é cerca de nove vezes menor, mas com a profundidade e devido ao comportamento diferente nas duas áreas, essa relação se alterna. 
O valor encontrado para cana-de-açúcar é cerca de duas vezes e meia maior ao encontrado para a mata.

O solo sob eucalipto, apresenta a mesma tendência da área com mata. Os valores são distintos entre as camadas e diminuem com a profundidade, passando de 11,3 $\mathrm{mmol}_{\mathrm{c}} \mathrm{dm}^{-3}$ de solo na camada mais superficial, para 5,6 $\mathrm{mmol}_{\mathrm{c}} \mathrm{dm}^{-3}$ de solo na camada mais profunda, Estes valores representam metade da acidez encontrada na camada superficial.

\subsubsection{Soma de bases}

$\mathrm{Na}$ área com mata nativa, a soma de bases diminuiu de $25,1 \mathrm{mmol}_{\mathrm{c}} \mathrm{dm}^{-3}$ de solo na camada $0-5 \mathrm{~cm}$ para $15,9 \mathrm{mmol}_{\mathrm{c}} \mathrm{dm}^{-3}$ de solo na camada $30-40 \mathrm{~cm}$. Uma diminuição de cerca de $40 \%$ em relação a primeira camada. Contudo esta diminuição que não é progressiva. Ocorre uma queda acentuada até a camada $20-30 \mathrm{~cm}$, e na camada seguinte volta a aumentar.

$\mathrm{Na}$ área com pastagem a soma de bases também diminuiu com a profundidade, porém de forma contínua. Variando de $47,3 \mathrm{mmol}_{\mathrm{c}} \mathrm{dm}^{-3}$ de solo na camada $0-5 \mathrm{~cm}$ até 25,7 $\mathrm{mmol}_{\mathrm{c}} \mathrm{dm}^{-3}$ de solo $(30-40 \mathrm{~cm})$. Em relação à mata, os valores são praticamente duas vezes maiores e, em algumas camadas, três vezes mais. Essa maior soma de bases se deve principalmente, às diferenças nos teores de cálcio e magnésio, que são muito superiores aos encontrados na área com mata nativa.

$\mathrm{Na}$ área com cana-de-açúcar, a soma de bases também diminui com a profundidade, seguindo o padrão da pastagem. Varia de $64,0 \mathrm{mmol}_{\mathrm{c}} \mathrm{dm}^{-3}$ de solo na camada 0-5 $\mathrm{cm}$ até $24,0 \mathrm{mmol}_{\mathrm{c}} \mathrm{dm}^{-3}$ de solo entre 30-40 $\mathrm{cm}$. Quando comparada a mata, a soma de bases é bem maior; em alguma camadas analisadas, chega a ser cinco vezes maior.

Como na área com pastagem, a diferença das somas de bases é condicionada pelas quantidades de cálcio e magnésio.

$\mathrm{Na}$ área com eucalipto a soma de bases também diminuiu com a profundidade variando de 13,2 $\mathrm{mmol}_{\mathrm{c}} \mathrm{dm}^{-3}$ solo na camada $0-5 \mathrm{~cm}$ até $12,7 \mathrm{mmol}_{\mathrm{c}} \mathrm{dm}^{-3}$ de solo. A diminuição ao longo do perfil, não segue um padrão. Pode-se observar que ocorre uma 
queda acentuada na soma de bases na segunda e terceira camadas analisadas e, em seguida começa a aumentar novamente, assim como acontece na área com mata.

Em síntese, pode-se dizer que em todas as áreas há uma diminuição da soma de bases com a profundidade. Uma análise comparativa das áreas cultivadas, evidencia que o solo sob cana-de-açúcar apresenta a maior soma de bases, seguida pela pastagem e eucalipto. A CTC segue essa mesma seqüência. Esse comportamento deve-se ao preparo do solo para os cultivos com calagem e adubação, que acabam compensando a maior acidez apresentada nas áreas com mata nativa e eucalipto.

\subsection{Mudanças na quantidade e qualidade da matéria orgânica do solo}

Nesse item serão apresentados e analisados os resultados referentes às porcentagens de carbono orgânico e nitrogênio no solo, assim como as respectivas quantidades em toneladas por hectare.

\subsubsection{Porcentagem de carbono}

$\mathrm{Na}$ tabela 4 estão registrados os valores das porcentagens de carbono ao longo do solo nas quatro situações estudadas.

A área de mata nativa, possui 5,61\% de carbono na camada mais superficial (0$5 \mathrm{~cm}$ ). Esta porcentagem diminui ao longo do solo, alcançando 1,56\% na camada mais profunda $(30-40 \mathrm{~cm})$. Ocorre uma diminuição de pelo menos três vezes na porcentagem de carbono na camada mais profunda em relação à camada mais superficial.

O principal responsável por estas diferenças nas porcentagens de carbono ao longo do solo, é quantidade de material orgânico que é incorporado para a decomposição. Nas camadas mais superficiais o volume deste material é bem superior quando comparado às camadas mais profundas.

Os teores de carbono do solo sob pastagem apresentam variações com a profundidade, diminuindo de $1,24 \%$ na camada $0-5 \mathrm{~cm}$ a $0,66 \%$ na camada mais profunda, uma redução em torno de $40 \%$. Comparados à mata esses valores são pelo menos quatro vezes menores na camada mais superficial, chegando a uma redução de cerca de $60 \%$ para a camada mais profunda. 
Tabela 4. Conteúdo de $\mathrm{C}$ orgânico e $\mathrm{N}$ total do solo sob mata e cultivado

\begin{tabular}{|c|c|c|c|c|c|c|c|}
\hline \multirow{2}{*}{$\begin{array}{l}\text { Prof. } \\
\mathrm{cm}\end{array}$} & \multicolumn{2}{|c|}{ Carbono } & \multicolumn{4}{|c|}{ Nitrogênio } & \multirow[t]{2}{*}{$\mathrm{C} / \mathrm{N}$} \\
\hline & $\%$ & t.ha $^{-1}$ & Acumulado & $\%$ & t.ha $^{-1}$ & Acumulado & \\
\hline \multicolumn{8}{|c|}{ Mata Natural } \\
\hline $0-5$ & 5,61 & 26,08 & 26,08 & 0,14 & 0,65 & 0,65 & 40 \\
\hline $5-10$ & 3,08 & 16,93 & 43,01 & 0,10 & 0,55 & 1,20 & 31 \\
\hline $10-20$ & 2,10 & 25,64 & 68,65 & 0,07 & 0,85 & 2,05 & 30 \\
\hline $20-30$ & 1,71 & 21,25 & 89,90 & 0,06 & 0,74 & 2,80 & 29 \\
\hline $30-40$ & 1,56 & 19,66 & 109,60 & - & - & & - \\
\hline \multicolumn{8}{|c|}{ Pastagem } \\
\hline $0-5$ & 1,24 & 7,36 & 7,36 & 0,05 & 0,30 & 0,30 & 25 \\
\hline $5-10$ & 0,91 & 6,29 & 13,65 & 0,05 & 0,35 & 0,65 & 18 \\
\hline $10-20$ & 0,67 & 9,32 & 22,97 & 0,04 & 0,56 & 1,21 & 17 \\
\hline $20-30$ & 0,63 & 8,09 & 31,06 & 0,04 & 0,52 & 1,73 & 16 \\
\hline $30-40$ & 0,66 & 8,34 & 39,40 & - & - & & - \\
\hline \multicolumn{8}{|c|}{ Cana-de-açúcar } \\
\hline $0-5$ & 0,65 & 3,87 & 3,87 & 0,03 & 0,16 & 0,16 & 22 \\
\hline $5-10$ & 0,62 & 4,10 & 7,97 & 0,03 & 0,20 & 0,36 & 21 \\
\hline $10-20$ & 0,60 & 7,91 & 15,88 & 0,03 & 0,39 & 0,75 & 20 \\
\hline $20-30$ & 0,60 & 8,65 & 24,53 & 0,03 & 0,43 & 1,18 & 20 \\
\hline $30-40$ & 0,60 & 8,87 & 33,40 & - & - & & $=$ \\
\hline \multicolumn{8}{|c|}{ Eucalipto } \\
\hline $0-5$ & 3,23 & 16,46 & 16,46 & 0,08 & 0,41 & 0,71 & 40 \\
\hline $5-10$ & 1,52 & 9,20 & 25,66 & 0,05 & 0,30 & 0,71 & 30 \\
\hline $10-20$ & 1,03 & 13,10 & 38,76 & 0,04 & 0,51 & 1,22 & 26 \\
\hline $20-30$ & 0,90 & 11,52 & 48,74 & 0,03 & 0,38 & 1,60 & 26 \\
\hline $30-40$ & 0,78 & 9,44 & 59,61 & - & - & & \\
\hline
\end{tabular}

(-) não analisado 
$\mathrm{Na}$ área com cana-de-açúcar os teores são os mais baixos entre as situações analisadas. Na camada mais superficial, encontra-se 0,65\% de carbono, enquanto que na camada mais profunda $0,60 \%$. As porcentagens encontradas nas camadas estudadas, não apresentam diferença estatisticamente significativas. Em comparação à mata nativa, os teores evidenciaram uma queda da ordem de seis vezes na camada mais superficial, enquanto que na camada mais profunda correspondem à cerca de $40 \%$.

O manejo e uso do solo, são os fatores que mais contribuem para a aceleração dos processos de mineralização da matéria orgânica (Stevenson, 1982), a queima e o corte anual da cana-de-açúcar, propiciam uma grande saída de carbono do sistema, diminuindo o teor deste elemento no solo.

A área com eucalipto é a que mais se aproxima daquela sob mata nativa. Apresenta decréscimo com a profundidade, passando de $3,23 \%$ na camada $0-5 \mathrm{~cm}$ a 0,78\% na camada $30-40 \mathrm{~cm}$, caracterizando uma redução de cerca de quatro vezes. Comparados à mata os teores encontrados para todas as camadas são cerca de $40 \%$ menores.

Nas quatro situações analisadas, as maiores concentrações de carbono estão nos primeiros dez centímetros do solo e diminuem gradativamente à medida que a profundidade aumenta.

Observa-se que nas área com eucalipto e mata a redução dos teores de carbono é mais acentuada ao longo do solo. Na área com eucalipto, na camada $30-40 \mathrm{~cm}$, os teores se eqüivalem àqueles encontrados para as áreas com cana-de-açúcar e pastagem, enquanto que na mata mesmo com a redução, o valor corresponde, ainda ao dobro das demais áreas.

Mann (1986) analisando amostras de solos arenosos (Inceptisols e Psammenst), com baixos teores de carbono, encontrou perdas da ordem de 13\%. Quando comparados a solos com uma porcentagem de carbono inicial maior essas perdas são consideravelmente menores. Segundo o autor solos com porcentagens iniciais menores de carbono apresentam menores perdas e em alguns casos ganhos de carbono com a implantação de culturas, indicando que está havendo, relativamente, maior entrada do que perda, em relação aos solos com quantidades iniciais maiores de carbono. 
Vários autores tem observado que a substituição da vegetação nativa por sistemas cultivados, provoca diminuição nos teores de carbono no solo. Martins et al (1990a) observaram, no Estado do Pará em solo do tipo Latossolo Podzolizado, um decréscimo da ordem de $40 \%$ nos teores de carbono do solo. Após cinco anos de cultivo com culturas anuais, em áreas sob pousio por três anos, com desenvolvimento de vegetação secundária, os teores de carbono representavam $80 \%$ daqueles encontrados no solo sob vegetação nativa. Cerri et al (1991), estudando uma cronossequência de introdução de cana-de-açúcar em solo do tipo LVE no Estado de São Paulo, observaram uma redução no estoque de carbono da ordem de 56\% após 50 anos de cultivo.

Nesse estudo, pode-se confirmar a ocorrência de diminuição nos teores de carbono nos solos cultivados, comparativamente à mata nativa.

\subsubsection{Conteúdo de carbono do solo}

$\mathrm{O}$ conteúdo de carbono em $\mathrm{t} \mathrm{ha}^{-1}$ é obtido multiplicando-se o teor de carbono de uma camada, pela densidade e espessura desta camada.

Os conteúdos de carbono são, portanto, dependentes da densidade do solo. Nota-se a influência desse parâmetro uma vez que em alguns casos, mesmo com uma porcentagem menor de carbono em uma camada, o conteúdo de carbono pode ser maior quando comparado a outra, justamente por esta camada apresentar maior densidade .

Os valores referentes aos conteúdos de carbono no solo, estão apresentados na tabela 4 e na figura 10 .

Analisando-se os conteúdos de carbono da área com mata nativa, observa-se que na camada mais superficial $(0-5 \mathrm{~cm})$ estão estocadas $26,1 \mathrm{tCha}^{-1} \mathrm{e}$, à medida que aumenta a profundidade, os conteúdos de carbono em cada camada diminuem em relação a camada superior. Na camada 30-40 cm apresenta 19,7 $\mathrm{tCha}^{-1}$, um decréscimo de cerca de $25 \%$ em relação à camada $0-5 \mathrm{~cm}$.

Na profundidade $5-10 \mathrm{~cm}$ o conteúdo de carbono é $16,9 \mathrm{t} \mathrm{ha}^{-1}$, demonstrando uma queda em relação a camada $0-5 \mathrm{~cm}$, fato que pode estar relacionado ‘a grande quantidade de raízes presente nessa camada. 


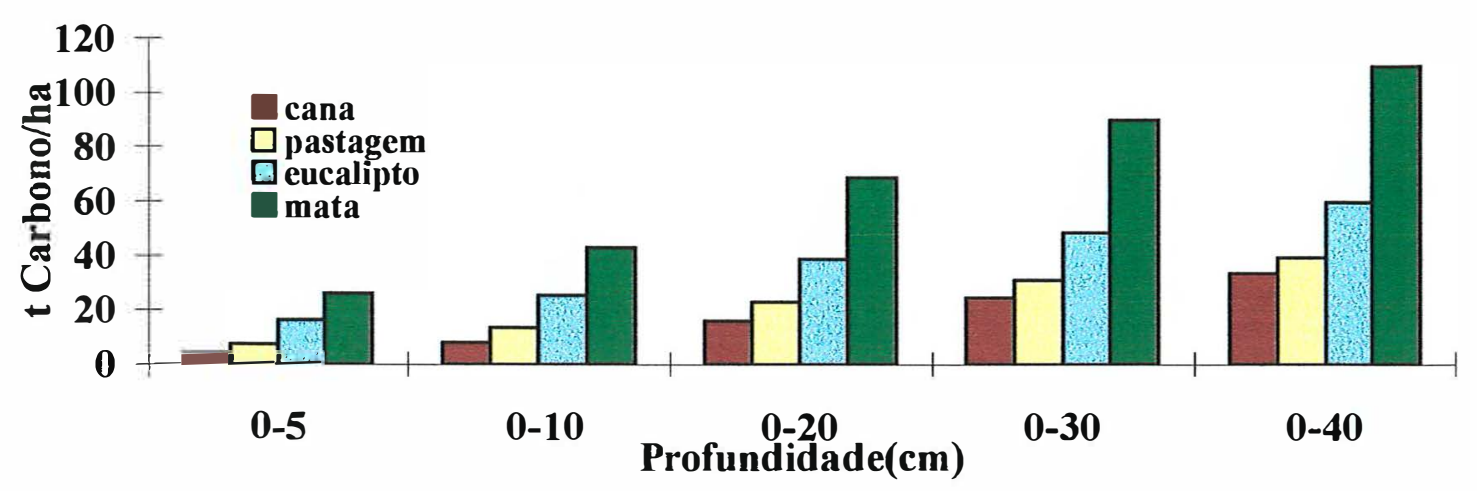

Figura 10 - Carbono estocado nas diversas profundidades do solo

Analisando, para efeito de comparação, o solo a cada dez centímetros, pode-se notar que na camada mais superficial, encontram-se $43 \mathrm{tCha}^{-1}$, o que representa aproximadamente $50 \%$ do carbono acumulado ao longo do perfil.

Verifica-se que os conteúdos de carbono na área com mata nativa são equivalentes aos encontrados por Geraldes (1993), superiores aos encontrados por Fernandes(1993), e bem inferiores aos encontrados por Cerri (1989).

$\mathrm{Na}$ área com pastagem, os conteúdos em carbono foram menores que os relatados na literatura. Contudo, nos trabalhos realizados são utilizadas pastagens bem manejadas, o que não é o caso deste estudo.

Na camada $0-5 \mathrm{~cm}$ o conteúdo é de $7,36 \mathrm{tha}^{-1}$, enquanto que na camada 5-10 $\mathrm{cm}$, ocorre uma diminuição do estoque, chegando a $6,29 \mathrm{t} \mathrm{ha}^{-1}$. Essa redução deve estar ligada a menor quantidade de raízes nesta camada, em relação a camada anterior. Considerando a camada 0-10 cm, para efeito de comparação, observamos um estoque de $13,65 \mathrm{tha}^{-1}$, que representa cerca de $34 \%$ do estoque total de carbono no solo. À medida que aumenta a profundidade o estoque de carbono diminui alcançando $8,34 \mathrm{t} \mathrm{ha}^{-1}$ na camada $30-40 \mathrm{~cm}(21 \%)$, demonstrando que a pastagem ainda não está em equilíbrio, diferentemente da área com mata nativa. A camada $10-20 \mathrm{~cm}$ apresenta $9,32 \mathrm{t} \mathrm{ha}^{-1}$, cerca de $23 \%$ do total acumulado, também é a camada que apresenta maior densidade, sugerindo a compactação do solo pelo pisoteio. Quando comparados à mata, os valores são pelo menos $50 \%$ menores nas camadas analisadas, enquanto que na camada mais superficial a redução no conteúdo de carbono em relação à mata é da ordem đe 70\%: 
$\mathrm{Na}$ área com cana-de-açúcar, os conteúdos de carbono praticamente não variam com a profundidade, situando-se entre 7,97 $\mathrm{t} \mathrm{ha}^{-1}$ nos dez centímetros iniciais do solo ( $24 \%$ do total), a $8,87 \mathrm{t} \mathrm{ha}^{-1}$ na camada $30-40 \mathrm{~cm}$ cerca de $26 \%$ do total acumulado ao longo do perfil. Os estoques nas últimas camadas aproximam-se daqueles encontrados para pastagem, seguindo a mesma tendência de diminuição em relação à mata, 72\% menor na camada $5-10 \mathrm{~cm}$ e $55 \%$ menor na camada $30-40 \mathrm{~cm}$. A distribuição praticamente homogênea do estoque de carbono no solo analisado, deve-se ao manejo anual que esta área recebe, que como mencionado anteriormente, envolve o revolvimento do solo a cada colheita.

Analisando os resultados obtidos na área com eucalipto, nota-se que os conteúdos de carbono, são os que mais se aproximam daqueles da mata nativa e apresentam a mesma tendência de diminuição ao longo do solo. Os conteúdos de carbono diminuíram com a profundidade, passando de $25,66 \mathrm{t} \mathrm{ha}^{-1}$ na camada $0-10 \mathrm{~cm}$ para 9,44 $\mathrm{t}$ $\mathrm{ha}^{-1}$ na camada $30-40 \mathrm{~cm}$, os quais representam, respectivamente, 43 e $16 \%$ do total acumulado. Na camada 5-10 $\mathrm{cm}$ o estoque de carbono de 9,20 $\mathrm{t} \mathrm{ha}^{-1}$ equivale a menos da metade do encontrado na camada $0-5 \mathrm{~cm}$, este fato está ligado a quantidade de material para a decomposição encontrado na camada mais superficial que é bem superior àquela encontrada nesta camada. As diferenças entre os conteúdos de carbono entre as profundidades na área com eucalipto em relação à área com mata, é da ordem de 50\%.

Moraes (1991), estudando duas cronossequências sob pastagem cultivada na Amazônia brasileira, observou para a camada $0-30 \mathrm{~cm}$ uma redução inicial no conteúdo de carbono nas duas cronossequências. Após vinte anos de cultivo a área com solo PVE apresentou uma perda de $25 \%$ em relação ao conteúdo inicial, e aquela com PVA, mais arenoso, apresentou um ganho de $14 \%$.

O uso agrícola de solos inicialmente pobres em carbono pode resultar em condições menos favoráveis para a mineralização quando comparados a solos com grandes quantidades iniciais de carbono. Essas condições são devidas a estes solos não possuírem substrato adequado tanto qualitativa como quantitativamente para a manutenção da população de decompositores (Jenny, 1980; Mann, 1986). 
A implantação de um sistema de cultivo que recobre totalmente o solo, como é o caso da pastagem, leva o sistema a uma recuperação dos estoques de carbono, em um período de tempo que é variável em função das propriedades de cada tipo de solo (Moraes, 1991).

\subsubsection{Porcentagem de nitrogênio}

Os teores de nitrogênio estão apresentados na tabela 4.

$\mathrm{Na}$ área com mata nativa, encontra-se $0,14 \%$ de nitrogênio na camada mais superficial e essa porcentagem diminui ao longo do perfil, alcançando 0,06\% na camada mais profunda analisada $(20-30 \mathrm{~cm})$. Esta variação corresponde a uma diminuição de pelo menos duas vezes em relação à camada superficial.

$\mathrm{Na}$ área com pastagem, os teores encontrados foram $0,05 \%$ na camada $0-5 \mathrm{~cm}$ e 0,04\% na camada $20-30 \mathrm{~cm}$, com uma redução de cerca de $20 \%$. Ao longo do solo, praticamente não houve variação. Estes teores são menores em relação aos da mata, sendo inferiores pelo menos três vezes na camada mais superficial e cerca de $35 \%$ na camada mais profunda,

Os valores apresentados na tabela 4 , indicam que na área com cana-de-açúcar, as porcentagens de nitrogênio foram as menores em relação às demais culturas estudadas, com apenas $0,03 \%$ de nitrogênio ao longo do perfil, não variando com a profundidade.

Comparativamente à mata nativa, a porcentagem de nitrogênio é pelo menos três vezes menor na camada mais superficial e, na mais profunda equivale à metade da encontrada para a área com mata nativa.

Os teores de nitrogênio na área com eucalipto foram os que mais se aproximaram daqueles encontrados para a área com mata nativa. $\mathrm{Na}$ camada $0-5 \mathrm{~cm}$ temse $0,08 \%$ de nitrogênio diminuindo para $0,03 \%$ na camada $20-30 \mathrm{~cm}$, com um decréscimo de pelo menos duas vezes e meia. Comparativamente à mata, o teor de nitrogênio na camada mais superficial foi cerca de $45 \%$ menor e na camada mais profunda, equivale à metade. 
A distribuição da porcentagem de nitrogênio ao longo do perfil foi semelhante a apresentada pelo carbono, tanto na diferença entre as culturas como na queda na porcentagem com a profundidade.

Os valores das porcentagens de nitrogênio encontrados para a área com mata, são semelhantes aos encontrados por Geraldes (1993), tanto na porcentagem quanto na redução ao longo do perfil.

Tem sido citado na literatura, que o nitrogênio é um dos elementos mais prejudicados quando um sistema natural é cultivado, apresentando nessa situação grandes perdas. Sanchez et al (1983), trabalhando com solos do tipo Ultisols na Amazônia colombiana, e Cerri et al (1991), no Estado de São Paulo em solos do tipo LVE encontraram perdas em torno de $56 \%$ de nitrogênio, em relação aos teores originalmente observados, como consequência do cultivo das áreas. Piccolo(1994) sustenta que existe uma relação entre as mudanças no uso da terra e a variação das taxas de nitrificação e mineralização, ocasionando intensa variabilidade no teor de $\mathrm{N}$ do solo.

Do mesmo modo que para o carbono, os teores mais elevados de nitrogênio também se concentraram nos primeiros dez centímetros do solo, passando por uma diminuição gradativa a medida que a profundidade aumentou.

Pode-se também observar que o manejo anual na área com cana-de-açúcar, que envolve aração, adubação e calagem, não garante maior porcentagem de nitrogênio para o solo dessa área, uma vez que o próprio preparo do terreno possibilitará maior perda de nitrogênio para a atmosfera, além da exportação ocasionada pela colheita da cana-deaçúcar. O que também pode-se supor que aconteça na área com pastagem, uma vez que nessa área não vem sendo colocado nenhum insumo a fim de melhorar a produção da área. 


\subsubsection{Conteúdo em nitrogênio do solo}

Os conteúdos de nitrogênio são calculados da mesma maneira utilizada para o carbono, trocando-se a porcentagem de carbono pela de nitrogênio no solo, e estão apresentados na tabela 4 e na figura 11.

$\mathrm{Na}$ área com mata nativa, a distribuição do conteúdo de nitrogênio ao longo do perfil foi de $1,20 \mathrm{tha}^{-1}$ na camada $0-10 \mathrm{~cm}$ e $0,74 \mathrm{t} \mathrm{ha}^{-1}$ na camada $20-30 \mathrm{~cm}$, ou seja,uma redução de cerca de $40 \%$.

Pode ser observado que, a exemplo do carbono, ocorre o mesmo padrão de distribuição e de diferenciação nos conteúdos ao longo do solo entre as culturas.

Os valores encontrados para a mata foram semelhantes aos de Geraldes (1993) e Fernandes (1993).

$\mathrm{Na}$ área com pastagem, o aumento no conteúdo com a profundidade foi significativo, passando de $0,65 \mathrm{tha}^{-1}$ na camada $0-10 \mathrm{~cm}$, para $0,52 \mathrm{t}^{-1} \mathrm{a}^{-1}$ na camada 20-30 $\mathrm{cm}$, uma variação em torno de $75 \%$.

Comparando à mata nota-se que na camada mais superficial, temos um conteúdo de nitrogênio praticamente duas vezes menor na área com pastagem, enquanto que na camada mais profunda o conteúdo na pastagem equivale a dois terços do encontrado para a mata.

Analisando cada cultura, pode-se notar que na área com cana-de-açúcar ocorreu um aumento significativo nos conteúdos de nitrogênio da camada $0-5 \mathrm{~cm}$ de 0,18 $\mathrm{t} \mathrm{ha}{ }^{-1}$, para $0,43 \mathrm{t} \mathrm{ha}^{-1}$ na camada $20-30 \mathrm{~cm}$, o que na última camada equivale a $36 \%$ do conteúdo total, mais do que duplicando o conteúdo nesta camada.

Comparando em relação à mata nativa, observa-se que o conteúdo de nitrogênio na camada mais superficial é pelo menos quatro vezes maior, enquanto que na mais profunda, esta diferença foi o dobro.

$\mathrm{Na}$ área com eucalipto, com uma diminuição no conteúdo de nitrogênio ao longo do perfil, a mesma tendência apresentada para o conteúdo de carbono também se confirma, esse decréscimo só não se fez mais pronunciado, pois na camada $10-20 \mathrm{~cm}$ ocorreu um aumento substancial no conteúdo de nitrogênio, assim como ocorrido com o carbono que acredita-se esteja relacionado com a densidade. 
Os conteúdos encontrados foram, na camada $0-10 \mathrm{~cm} 0,71 \mathrm{t} \mathrm{ha}^{-1}$, enquanto na camada $30-40 \mathrm{~cm} 0,38 \mathrm{t} \mathrm{ha}^{-1}$, demonstrando uma redução de cerca de $50 \%$ em relação à camada mais superficial.

Nas camadas analisadas, os conteúdos de nitrogênio encontrados para a área com eucalipto foram praticamente a metade, quando comparados à mata. $\mathrm{O}$ acúmulo de nitrogênio ao longo do solo está demonstrado na Figura 11.

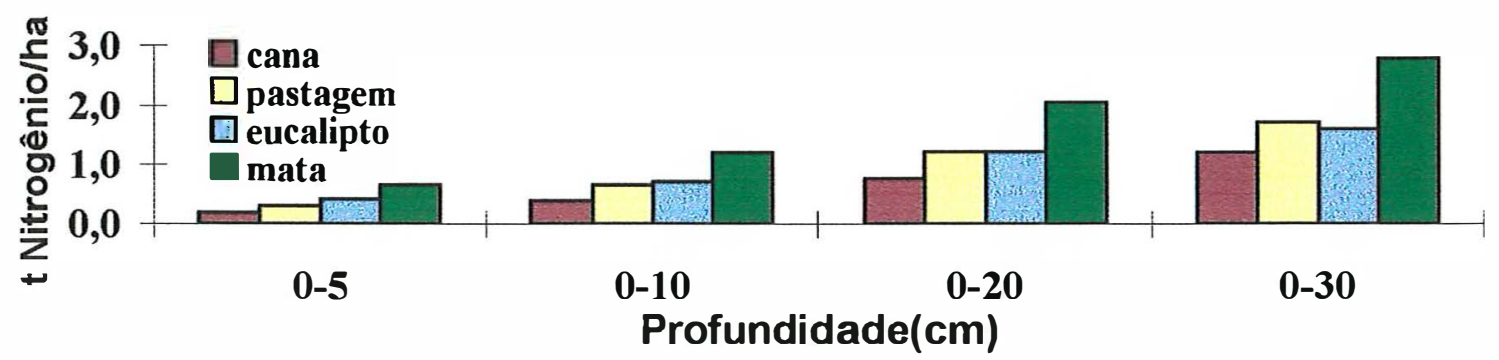

Figura 11- Nitrogênio estocado nas diversas profundidades

\subsubsection{Relação $\mathrm{C} / \mathrm{N}$}

As relações $\mathrm{C} / \mathrm{N}$ ao longo do solo nas quatro culturas estudadas estão apresentadas na tabela 4 e na figura 12.

A relação $\mathrm{C} / \mathrm{N}$ na área com mata nativa sofreu uma pequena alteração ao longo do perfil, passando de 40 na camada mais superficial para 29 na camada $30-40 \mathrm{~cm}$, uma diminuição de cerca de $30 \%$.

A área que apresentou a menor relação $\mathrm{C} / \mathrm{N}$, foi a da pastagem, com uma relação $\mathrm{C} / \mathrm{N}$ de 25 na camada $0-5 \mathrm{~cm}$, diminuindo para 16 na camada $30-40 \mathrm{~cm}$.

$\mathrm{Na}$ área com cana-de-açúcar a relação praticamente não se alterou com a profundidade. Os valores oscilaram entre 22 e 20 . Esta pequena alteração da relação C/N deve estar ligada ao preparo anual do solo que todo ano é revolvido pela aração.

A área com eucalipto foi a que apresentou a relação $\mathrm{C} / \mathrm{N}$ mais elevada, de todas as áreas estudadas. A relação chegou a 40 na camada mais superficial, baixando para 26 na camada $30-40 \mathrm{~cm}$, com um decréscimo de pouco mais de $35 \%$. Essa relação mais elevada deve ser pelo material que é depositado para a decomposição, tornando esta decomposição mais lenta e contribuindo para o aumento do estoque no solo. 


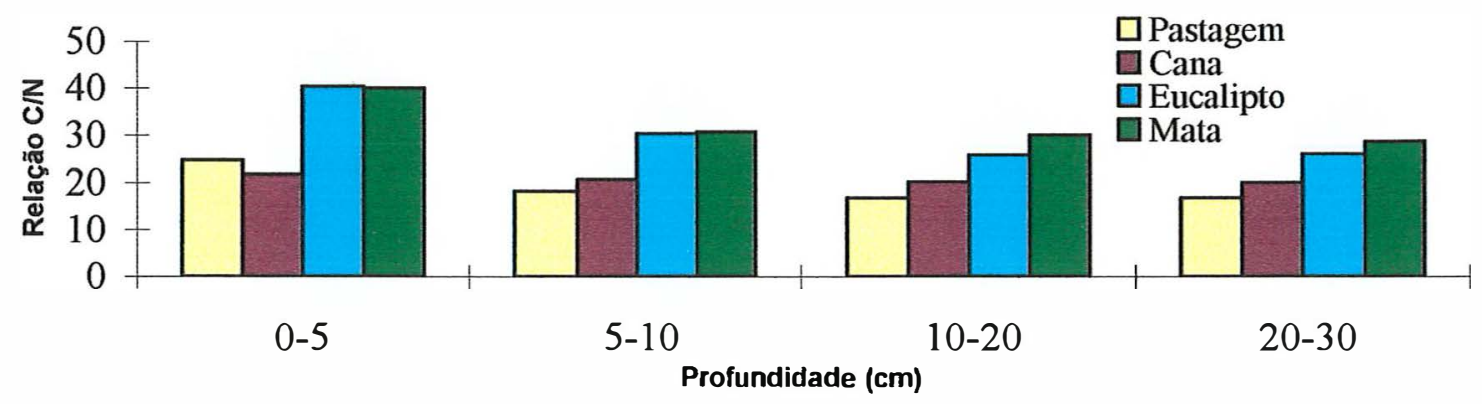

Figura 12 - Relação $\mathrm{C} / \mathrm{N}$ ao longo do perfil nas quatro culturas estudadas

\subsection{Dinâmica da Matéria Orgânica do solo devido às alterações no uso da terra}

Em agrossistemas podem ser observados dois processos simultâneos de evolução do carbono orgânico do solo: a contínua mineralização do carbono derivado da vegetação nativa e a progressiva incorporação do carbono derivado dos restos das culturas introduzidas. Para a quantificação dessas diferentes fontes de carbono utilizou-se a variação da relação isotópica $\delta^{13} \mathrm{C}$.

Os dados referentes a distribuição dos valores da constituição isotópica de acordo com as profundidades nas áreas cultivadas com pastagem e cana-de-açúcar e de mata nativa, bem como a quantidade de carbono presente no solo derivado da nova cobertura vegetal, e ainda as porcentagens de carbono remanescente da mata, estão representados na tabela 5 .

$\mathrm{Na}$ área sob mata nativa o $\delta^{13} \mathrm{C}$ é de aproximadamente $-29,0 \%$ na camada superficial, bem próximo aos valores encontrados por Cerri et al (1991), Geraldes(1993) e Fernandes(1993). A profundidades maiores este valor tende a aumentar, sem contudo, variar muito até a camada estudada, cujo valor é de $-28,5 \%$.

Com a introdução da pastagem, o $\delta^{13} \mathrm{C}$ do solo aumenta progressivamente, já que ocorre uma diluição isotópica através da entrada de material orgânico proveniente das gramíneas. Esta variação é maior nas camadas mais superficiais do solo e a medida que aumenta a profundidade, a diluição isotópica ocasionada pela entrada dos restos vegetais da pastagem torna-se menor, e o $\delta^{13} \mathrm{C}$ da pastagem tende a valores inferiores.

Os valores encontrados foram de aproximadamente $-16,1 \%$ na camada superficial, diminuindo para - 20,3\%, na camada $20-30 \mathrm{~cm}$. 
$\mathrm{Na}$ área com cana-de-açúcar, ocorreu um aumento do $\delta^{13} \mathrm{C}$, quando comparado à mata nativa. Porém em relação a pastagem, que foi a cultura usada antes da substituição por cana-de-açúcar, ocorreu uma diminuição, já que esta cultura contribui bem menos com aporte de matéria orgânica ao solo em relação à pastagem. Os valores variaram de -19,2\%o na camada mais superficial até $-23,9 \%$ na camada mais profunda. Nota-se também que os valores das camadas $0-5 \mathrm{~cm}$ e $5-10 \mathrm{~cm}$ praticamente não variaram, o que deve estar associado ao preparo anual do terreno, que resulta no revolvimento do solo, minimizando as diferenças entre as camadas estudadas.

Com a volta ao sistema de uma planta com ciclo fotossintético $\mathrm{C}_{3}$, a constituição isotópica passa por grande alteração, sinalizando para uma volta à constituição isotópica equivalente àquela encontrada para a área com mata nativa.

Os valores variam de $-28,6 \%$ na camada $0-5 \mathrm{~cm}$ até $-24,2 \%$ na camada $30-$ $40 \mathrm{~cm}$. Na camada mais superficial, devido à maior influência do material depositado para a decomposição, o valor do $\delta^{13} \mathrm{C}$ é próximo ao encontrado para a mata; já nas camadas mais profundas os valores são maiores.

Nota-se que com a volta ao sistema de uma planta $\mathrm{C}_{3}$, a diminuição da constituição isotópica é mais rápida do que a elevação desta constituição, devido à entrada de uma planta $\mathrm{C}_{4}$. Pode se observar que para a ocorrência de um aumento para $13 \%$ foram necessários pelo menos sessenta anos, enquanto que com vinte anos de cultivo com eucalipto, após a substituição da pastagem, essa constituição baixou para 12,5\%. Isso indica que a deposição de material é maior em cultivo de eucaliptos que em áreas com pastagem. 
Tabela 5. Conteúdos de carbono total $(\mathrm{Ct})$, carbono derivado da mata $(\mathrm{Cdm})$ e carbono derivado da cultura $(\mathrm{Cdc})$ nas quatro situações estudadas

\begin{tabular}{|c|c|c|c|c|}
\hline Prof. & $\delta^{13} \mathrm{C}$ & $\mathrm{Ct}$ & Cdm & Cdc \\
\hline$(\mathbf{c m})$ & $\%$ & & $\mathrm{tha}^{-1}$ & \\
\hline \multicolumn{5}{|c|}{ Mata Natural } \\
\hline $0-5$ & $-29,1$ & 26,1 & 26,1 & \\
\hline $5-10$ & $-29,1$ & 16,9 & 16,9 & \\
\hline $10-20$ & $-28,6$ & 25,6 & 25,6 & \\
\hline $20-30$ & $-28,5$ & 21,3 & 21,3 & \\
\hline $30-40$ & $-28,2$ & 19,6 & 19,6 & \\
\hline \multicolumn{5}{|c|}{ Pastagem } \\
\hline $0-5$ & $-16,1$ & 7,4 & 0,7 & 6,7 \\
\hline $5-10$ & $-18,4$ & 6,3 & 1,6 & 4,7 \\
\hline $10-20$ & $-18,9$ & 9,3 & 3,3 & 6,0 \\
\hline $20-30$ & $-20,3$ & 8,1 & 4,0 & 4,1 \\
\hline $30-40$ & $-22,1$ & 8,3 & 5,3 & 3,0 \\
\hline \multicolumn{5}{|c|}{ Cana-de-açúcar } \\
\hline $0-5$ & $-19,2$ & 3,9 & 1,7 & 2,2 \\
\hline $5-10$ & $-19,0$ & 4,1 & 1,7 & 2,4 \\
\hline $10-20$ & $-21,5$ & 7,9 & 4,9 & 3,0 \\
\hline $20-30$ & $-23,5$ & 8,7 & 7,2 & 1,5 \\
\hline $30-40$ & $-24,9$ & 8,9 & 8,1 & 0,8 \\
\hline
\end{tabular}

Com a introdução de carbono de outra fonte, que não mais a mata nativa, o conteúdo desse elemento no solo sofre uma diferenciação. Nas áreas com pastagem, canade-açúcar e eucalipto, o carbono que está sendo mineralizado não é proveniente apenas das incorporações ao solo ocasionadas por essas culturas, mas grande parte ainda é originária da mata nativa. 
Na tabela 5 e na figura 13, ainda, pode-se estimar quanto do carbono existente no solo é proveniente da nova cobertura vegetal, e quanto é remanescente da vegetação original (através da relação entre o $\delta^{13} \mathrm{C}$ das plantas $\mathrm{C}_{3}$ e $\mathrm{C}_{4}$ ).

$\mathrm{Na}$ área com pastagem, do total de $7,4 \mathrm{tCha}^{-1}$, encontrado na camada superficial, 6,7 $\mathrm{tCha}^{-1}$ é originário da incorporação dos restos vegetais da pastagem, perfazendo um total de cerca de $90 \%$. Isso indica que nesta camada, apenas $10 \%$ do carbono é remanescente da mata nativa.

Em função do aumento da profundidade a porcentagem de carbono remanescente da mata nativa aumenta. Na camada mais profunda a quantidade de carbono proveniente da pastagem é de $3,0 \mathrm{tCha}^{-1}$, o que equivale a cerca de $34 \%$, com $66 \%$ do carbono nesta profundidade remanescente da mata nativa.

$\mathrm{Na}$ área com cana-de-açúcar, será analisado o remanescente da vegetação nativa, já que pelo fato da cana-de-açúcar e da pastagem possuírem o mesmo ciclo fotossintético $\left(\mathrm{C}_{4}\right)$, não é possível, através do estudos realizados, afirmar que o carbono originário da nova vegetação refere-se exclusivamente aos aportes ocasionados pela cultura da cana-de-açúcar. De um total de 3,9 t $\mathrm{C} \mathrm{ha}^{-1}$ existente na camada superficial, 2,2 ton. são originárias da nova cobertura sendo 1,7 ton proveniente da mata nativa, o que totaliza cerca de $43 \%$ de carbono remanescente da vegetação original. Na camada mais profunda o remanescente da mata nativa é ainda maior, 0,8 ton oriundas na nova cobertura com 8,1 ton originário da mata nativa, o que demonstra que mais de $91 \%$ do carbono existente nesta camada ainda é remanescente da mata.

Para a área com eucalipto, não é possível determinar o remanescente da mata nativa, o proveniente da pastagem e quanto é oriundo da nova cobertura, já que não foram analisadas as frações físicas da matéria orgânica do solo. Essas análises permitiriam distinguir as porções estáveis e biodegradáveis, que serviriam como indicativo do comportamento do carbono no solo, já que o material orgânico mais recente, proveniente do eucalipto, seria mais biodegradável, enquanto que o remanescente das outras situações estaria sob a forma mais estável. 
Pastagem

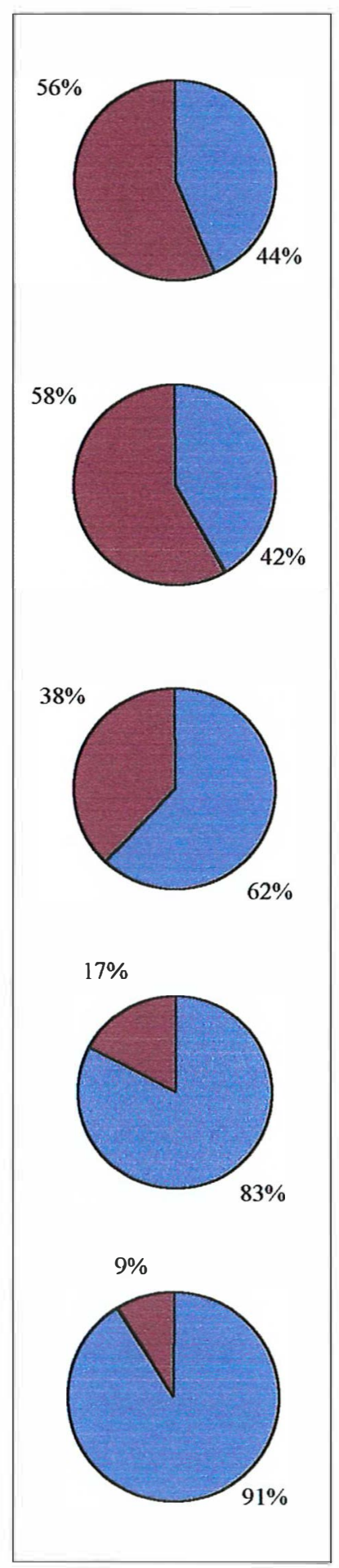

Cana-de-açúcar

$0-5 \mathrm{~cm}$

$5-10 \mathrm{~cm}$

$10-20 \mathrm{~cm}$

20-30 cm

$30-40 \mathrm{~cm}$

Carbono

Introduzido

Remanescente

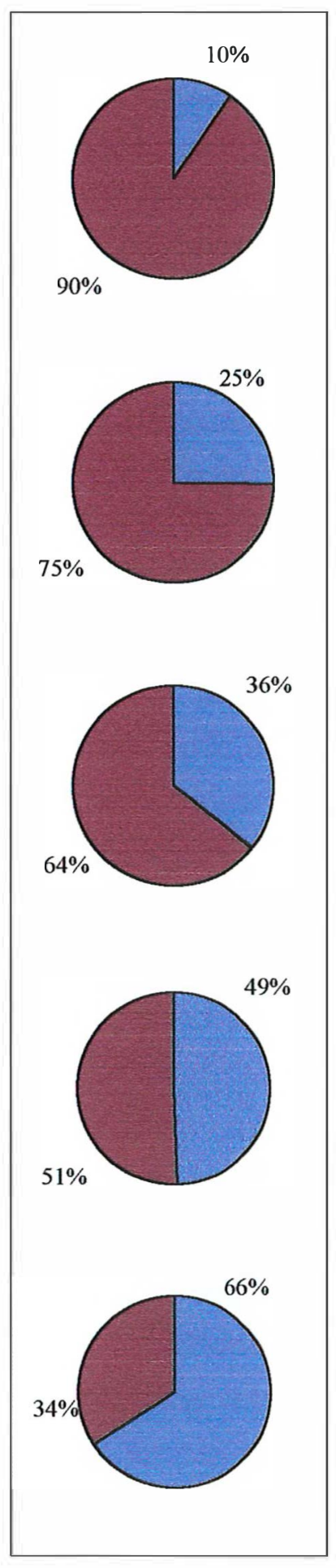

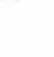




\subsection{Estimativa da biomassa microbiana do solo sob diferentes culturas}

Os valores referentes à estimativa da biomassa microbiana $\mathrm{C}$ e $\mathrm{N}$ encontram-se na Tabela 6. Neste estudo será analisada como camada superficial os dez centímetros iniciais do solo. Essa alteração se faz necessária a fim de permitir comparações com dados da literatura, já que na maioria dos trabalhos o solo foi analisado a cada dez centímetros

\subsubsection{Biomassa microbiana Carbono}

$\mathrm{Na}$ área com mata nativa, na camada $0-10 \mathrm{~cm}$ estimou-se uma biomassa microbiana $\mathrm{C}$ de $382,3 \mu \mathrm{g} \mathrm{C} \mathrm{g}^{-1}$ solo, que representa $44 \%$ da biomassa total. Com o aumento da profundidade, ocorre diminuição nos valores de biomassa, alcançando 225,1

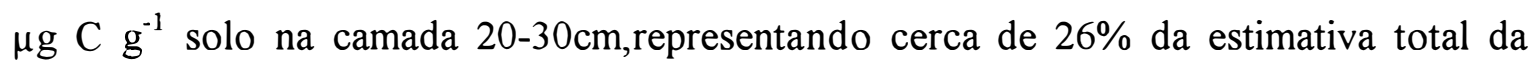
biomassa. Nota-se uma redução da ordem de $42 \%$ com a profundidade. Os valores de biomassa são próximos aos encontrados por Geraldes (1993) e Uzêda (1995).

Esta maior concentração da biomassa, na camada mais superficial, deve-se a maior aeração e quantidade de matéria orgânica facilmente decomponível presente nesta camada. Com a profundidade, a quantidade de matéria orgânica diminui, acarretando uma redução equivalente na estimativa da biomassa microbiana.

$\mathrm{Na}$ área com pastagem, a biomassa estimada na camada superficial é de

$213,1 \mu \mathrm{g} \mathrm{C} \mathrm{g}^{-1}$ solo, representando cerca de $37 \%$ do total da biomassa no solo. Com o aumento da profundidade, ocorre uma diminuição da ordem de $25 \%$ na biomassa, alcançando $160,8 \mu \mathrm{g} \mathrm{C} \mathrm{g}^{-1}$ solo que corresponde a cerca de $28 \%$ da biomassa estimada para este solo.

A redução da biomassa do solo sob pastagem, é menor quando comparada à área com mata nativa. Este fato esta ligado à grande quantidade de raízes presentes a esta profundidade, e também à quantidade de matéria orgânica no solo. Enquanto sob mata o teor de carbono é cerca de quatro vezes menor na camada $30-40 \mathrm{~cm}$, na pastagem, equivale a praticamente metade daquele encontrado na camada mais superficial. 
Tabela 6. Estimativa da biomassa microbiana $\mathrm{C}$ e $\mathrm{N}$ (BMC e BMN) pelo método da extração e Porcentagem de Carbono e Nitrogênio sob a forma de biomassa microbiana $(\mathrm{CBM}=$ Carbono sob a forma de Biomassa Microbiana; $\mathrm{NBM}=$ Nitrogênio sob a forma de Biomassa Microbiana).

\begin{tabular}{|c|c|c|c|c|}
\hline \multirow[t]{2}{*}{ Prof. } & \multicolumn{2}{|c|}{ Biomassa Microbiana } & \multirow{2}{*}{$\begin{array}{c}\text { CBM } \\
(\mathrm{BMC} / \% \mathrm{C}) / 100)\end{array}$} & \multirow{2}{*}{$\begin{array}{c}\text { NBM } \\
(\mathrm{BMN} / \% \mathrm{~N}) / \mathbf{1 0 0})\end{array}$} \\
\hline & Carbono & Nitrogênio & & \\
\hline$(\mathbf{c m})$ & \multicolumn{2}{|c|}{ 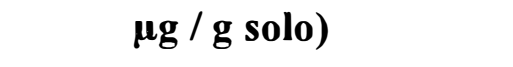 } & \multicolumn{2}{|c|}{$\%$} \\
\hline \multicolumn{5}{|c|}{ Mata Natural } \\
\hline 0-10 & 382,36 & 67,67 & 0,90 & 5,64 \\
\hline $10-20$ & 259,16 & 47,52 & 2,52 & 6,79 \\
\hline $20-30$ & 225,10 & 40,71 & 2,50 & 6,78 \\
\hline \multicolumn{5}{|c|}{ Pastagem } \\
\hline 0-10 & 213,15 & 24,44 & 2,01 & 4,89 \\
\hline $10-20$ & 197,20 & 21,35 & 4,48 & 5,34 \\
\hline $20-30$ & 160,84 & 18,67 & 4,02 & 4,67 \\
\hline \multicolumn{5}{|c|}{ Cana-de-açúcar } \\
\hline 0-10 & 151,12 & 4,96 & 2,40 & 1,65 \\
\hline $10-20$ & 144,95 & 8,07 & 3,37 & 2,69 \\
\hline $20-30$ & 168,36 & 7,90 & 4,01 & 2,63 \\
\hline \multicolumn{5}{|c|}{ Eucalipto } \\
\hline 0-10 & 96,57 & 16,38 & 0,42 & 2,73 \\
\hline $10-20$ & 28,31 & 10,28 & 0,50 & 2,57 \\
\hline $20-30$ & 10,82 & 8,91 & 0,21 & 2,97 \\
\hline
\end{tabular}

Em comparação à mata nativa, nos dez centímetros iniciais, a biomassa corresponde a cerca de $56 \%$ da encontrada para aquela área, enquanto que na camada mais profunda, equivale a cerca de $71 \%$.

$\mathrm{Na}$ área com cana-de-açúcar, a biomassa na camada superficial é $151,1 \mu \mathrm{g} \mathrm{C} \mathrm{g}^{-1}$ solo, representando cerca de $32 \%$ do total da biomassa no solo. Com o aumento da profundidade, ocorre aumento da ordem de $10 \%$, alcançando $168,3 \mu \mathrm{g} \mathrm{C} \mathrm{g}^{-1}$ solo que 
corresponde a cerca de $36 \%$ da biomassa estimada. Esse fato deve estar associado ao manejo anual do solo, que o torna mais homogêneo no que tange às suas características. Em comparação à mata nativa, nos dez centímetros iniciais, a biomassa corresponde a cerca de $40 \%$ da encontrada para aquela área, enquanto que na camada mais profunda , equivale a cerca de $75 \%$.

$\mathrm{Na}$ área com eucalipto, na camada $0-10 \mathrm{~cm}$, estimou-se uma biomassa microbiana de 9,6 $\mu \mathrm{g} \mathrm{C} \mathrm{g}^{-1}$ solo, o que representa cerca de $71 \%$ da biomassa total. Com o aumento da profundidade a biomassa diminui, alcançado $10,82 \mu \mathrm{g} \mathrm{C} \mathrm{g}^{-1}$ solo na camada $20-30 \mathrm{~cm}$, representando cerca de $8 \%$ da biomassa total estimada. Nota-se neste caso, uma redução de cerca de $89 \%$ com a profundidade.

A biomassa microbiana estimada nesta área, foi a mais baixa em relação às quatro situações estudadas, ocorrem ainda, as maiores variações entre as profundidades. Em comparação à mata, na camada superficial, a biomassa microbiana equivale a cerca de $75 \%$ da biomassa estimada para aquela área, enquanto que na camada $20-30 \mathrm{~cm}$ equivale a cerca de $95 \%$. Esses menores valores na estimativa de biomassa devem estar ligados à ação alelopática, devido às substâncias liberadas no solo pela cultura.

As reduções da biomassa encontradas para as áreas cultivadas, quando comparadas à mata, estão de acordo com trabalhos anteriores (Geraldes (1993) e Uzêda (1995)), que registraram diminuição da biomassa a níveis iguais ou inferiores à metade dos valores encontrados em áreas com floresta. Esta diminuição pode estar relacionada às modificações causadas na estrutura do solo, bem como na quantidade e qualidade da matéria orgânica no solo, que sofre nítidas modificações com a substituição da mata nativa por outras culturas. 


\subsubsection{Biomassa microbiana nitrogênio}

$\mathrm{Na}$ área com mata nativa, a biomassa $\mathrm{N}$ estimada é de $136,0 \mu \mathrm{g} \mathrm{N} \mathrm{g}^{-1}$ solo, que corresponde a $60 \%$ da biomassa estimada para essa área. Com o aumento da profundidade, ocorre a diminuição da biomassa, alcançando $40,7 \mu \mathrm{g} \mathrm{N} \mathrm{g}^{-1}$ solo na camada 20-30 cm, representando cerca de $18 \%$ da biomassa total estimada. Pode-se notar uma redução da biomassa microbiana $\mathrm{N}$ bem acentuada com a profundidade, atingindo a ordem de $70 \%$ em relação à camada mais superficial do solo.

$\mathrm{Na}$ área com pastagem, a biomassa é de $48,9 \mu \mathrm{g} \mathrm{Ng}^{-1}$ solo na camada $0-10 \mathrm{~cm}$ ( $55 \%$ do total), e diminui com nas camadas mais profundas, alcançando $18,7 \mu \mathrm{g} \mathrm{N} \mathrm{g}^{-1}$ solo na camada $20-30 \mathrm{~cm}(21 \%$ do total).

A redução da biomassa ao longo do perfil é de cerca de $62 \%$. Esta redução é menor, quando comparada a ocorrida na área com mata nativa. Em valores absolutos, a biomassa $\mathrm{N}$ na camada superficial, é praticamente três vezes menor, enquanto que na camada mais profunda equivale a pouco menos da metade daquela encontrada na área com mata nativa. O que provavelmente condiciona essa diferença, é a quantidade maior de raízes na área com pastagem.

A área com cana-de-açúcar, apresenta a menor estimativa de biomassa microbiana $\mathrm{N}$. Na camada mais superficial, a biomassa estimada é de $9,6 \mu \mathrm{g} \mathrm{N} \mathrm{g}^{-1}$ solo, o que representa $37 \%$ da biomassa total estimada. Com o aumento da profundidade ocorre a diminuição, alcançando $7,9 \mu \mathrm{g} \mathrm{N} \mathrm{g}^{-1}$ solo na camada $20-30 \mathrm{~cm}$. A biomassa estimada para esta profundidade representa cerca de $31 \%$ da biomassa total. Pode-se notar nesta área, que a redução da biomassa com a profundidade, cerca de $20 \%$, foi muito menor que nas outras áreas estudadas. Esse fato deve estar ligado ao manejo, que possibilita uma homogenização do solo. Comparativamente a mata nativa, a biomassa estimada, na camada mais superficial é quatorze vezes menor, enquanto que na camada mais profunda a biomassa na área com cana-de-açúcar é cinco vezes menor.

Esta grande diferença, também pode ser explicada pelo manejo, que mesmo possibilitando a adição de adubos nitrogenados ao solo, com o revolvimento e conseqüente aumento da aeração, acarreta maior mineralização deste nitrogênio, ocasionando um estoque muito baixo deste elemento, principalmente nas camadas mais 
superficiais, que estão mais sujeitas às ações do ámbiente, como pôde ser visto no tópico específico.

$\mathrm{Na}$ área com eucalipto, a estimativa da biomassa na camada $0-10 \mathrm{~cm}$ é de $32,9 \mu \mathrm{g} \mathrm{N} \mathrm{g}^{-1}$ solo, o que representa cerca de $62 \%$ do total. Com o aumento da profundidade, a biomassa diminui, alcançando $8,9 \mu \mathrm{g} \mathrm{N} \mathrm{g}^{-1}$ solo(17\%). Esta variação está de acordo com a porcentagem de nitrogênio, que é maior na camada mais superficial. Esta é a área que apresenta a maior variação da estimativa de biomassa, com uma diminuição de aproximadamente $75 \%$ ao longo do solo. Nesse aspecto é semelhante à área com mata nativa, onde a diminuição é de cerca de $70 \%$. As porcentagens relativas em cada profundidade também se equivalem.

Comparando-se, em relação à mata nativa, os valores de biomassa, em todas as camadas estudadas, a biomassa estimada é cerca de quatro vezes menor.

Em síntese, a biomassa microbiana $\mathrm{N}$ concentrou-se nos $10 \mathrm{~cm}$ iniciais do solo, correspondendo a $63 \%, 55 \%, 38 \%$ e $61 \%$ da biomassa total dos solos estudados nas áreas com mata nativa, pastagem, cana-de-açúcar e eucalipto respectivamente.

Os valores obtidos com a estimativa da biomassa microbiana $\mathrm{N}$, mostram a mesma tendência da biomassa microbiana $\mathrm{C}$. As reduções da biomassa $\mathrm{C}$ e $\mathrm{N}$ com a profundidade, coincidem com a diminuição dos teores de $\mathrm{C}$ e $\mathrm{N}$, sendo mais acentuadas nas áreas de eucalipto e mata.

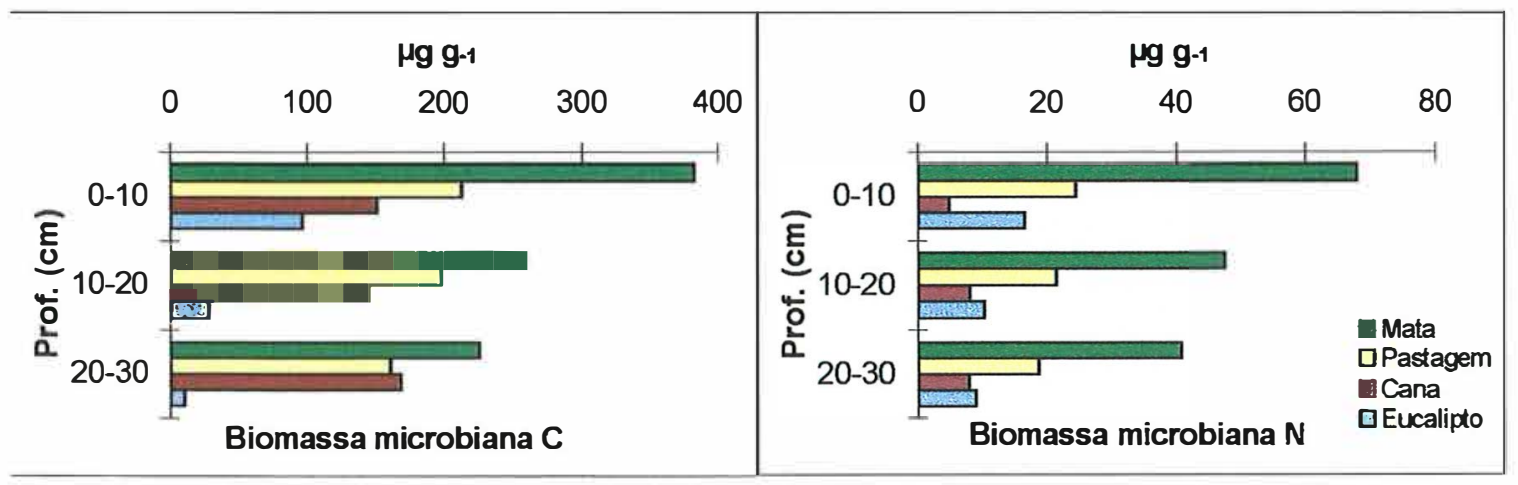

Figura 14 - Distribuição da biomassa microbiana $(\mathrm{C}$ e N) ao longo do solo nas áreas estudadas 


\subsubsection{Relação entre $C$ total, $N$ total e Biomassa microbiana $C$ e $N$}

Os resultados apresentados na Tabela 6 indicam a relação existente entre a biomassa $\mathrm{C}$ e $\mathrm{N}$ e os teores de carbono e nitrogênio do solo.

$\mathrm{Na}$ área com mata nativa, na camada $0-10 \mathrm{~cm}$, a porcentagem de carbono imobilizado como biomassa microbiana é de $0,90 \%$, a medida que aumenta a profundidade a porcentagem aumenta, alcançando $1,31 \%$ na camada $20-30 \mathrm{~cm}$. Nota-se um aumento de cerca de $45 \%$ na porcentagem de carbono sob a forma de biomassa microbiana.

$\mathrm{Na}$ área com pastagem, na camada $0-10 \mathrm{~cm}$, a porcentagem de carbono imobilizado como biomassa microbiana é de 2,01\%, com o aumento da profundidade, a porcentagem também aumenta, alcançando 2,55\% na camada $20-30 \mathrm{~cm}$. Nota-se nesse caso, um aumento de aproximadamente $27 \%$ na porcentagem de carbono sob a forma de biomassa microbiana.

Em relação à mata nativa a porcentagem de carbono imobilizado sob a forma de biomassa é pelo menos duas vezes maior nas camadas analisadas. Essa diferença deve estar associada a atividade microbiana que possivelmente é maior nesta área, e também `a quantidade de raízes que também é mais elevada.

$\mathrm{Na}$ área com cana-de-açúcar, na camada mais superficial, a porcentagem de carbono como biomassa, é de $2,40 \%$, com a profundidade ocorre aumento nessa porcentagem, alcançando 2,80 na camada $20-30 \mathrm{~cm}$. Para essa área, ocorre um aumento de $16 \%$ na relação. Entre as camadas $0-10$ e $10-20 \mathrm{~cm}$ não ocorre diferença nas relações entre a biomassa e o teor de carbono. Em comparação com a mata, essa porcentagem é duas vezes e meia maior na camada mais superficial, enquanto que na camada $20-30 \mathrm{~cm}$ é praticamente duas vezes maior.

O carbono imobilizado como biomassa microbiana na área de eucalipto foi o menor encontrado. Na camada $0-10 \mathrm{~cm}$, encontra-se $0,42 \%$ e com o aumento da profundidade ocorre diminuição de três vezes e meia nessa porcentagem, alcançando 0,12\%. Em comparação com a mata, essa porcentagem é duas vezes menor na camada mais superficial, enquanto que na camada $20-30 \mathrm{~cm}$ é praticamente dez vezes menor. 
A área com mata é a que apresenta a menor variação na relação com a profundidade, sendo que na camada mais profunda, as relações da cana e da pastagem se igualaram.

A área com cana-de-açúcar, é a que apresenta a maior porcentagem de carbono como biomassa microbiana. Essa diferença deve estar ligada ao manejo que esta área sofre. Com o preparo anual, ocorre maior aeração e adição de insumos no solo, o que possibilita maior atividade da biomassa microbiana.

Estes resultados demonstram que a relação entre a biomassa microbiana e o carbono do solo, é superior à encontrada por Geraldes (1993)

O nitrogênio imobilizado como biomassa microbiana foi maior na área com mata, os valores foram superiores aos encontrados por Geraldes (1993), com cerca de $5,64 \%$ nos $10 \mathrm{~cm}$ iniciais do solo. Com a profundidade, ocorre aumento da porcentagem de nitrogênio sob a forma de biomassa, alcançando $6,78 \%$ na camada mais profunda. Demonstrando um aumento de $20 \%$ na relação.

A área com pastagem foi a que apresentou a relação mais próxima à encontrada na área com mata, com 4,89\% na camada $0-10 \mathrm{~cm}$. Na camada $10-20 \mathrm{~cm}$ ocorre um aumento nà relação, alcançando 5,34\%, coincidindo com o aumento no conteúdo de nitrogênio e na camada seguinte diminui alcançando 4,67\%. Entre as camadas analisadas, não há diferença estatisticamente significativa.

Em comparação à mata, na camada superficial, a relação encontrada para a pastagem é $15 \%$ menor, enquanto que na camada mais profunda essa diferença chega a $45 \%$, diferentemente do que ocorre na relação da biomassa microbiana com o carbono.

$\mathrm{Na}$ área com cana-de-açúcar, na camada $0-10 \mathrm{~cm}$ é encontrado $1,65 \%$ de nitrogênio como biomassa, com o aumento da profundidade ocorre aumento desta relação alcançando 2,63\% na camada mais profunda. Isso indica um aumento de cerca de $60 \%$. Esta área é a que apresenta a menor porcentagem de nitrogênio sob a forma de biomassa microbiana, este fato deve estar ligado ao manejo e preparo anual que o terreno sofre, o que possibilita maior perda desse elemento, não sendo possível estocá-lo sob a forma de biomassa, como foi comprovado com a estimativa da biomassa microbiana $\mathrm{N}$. 
Em comparação à mata, na camada superficial, a relação é três vezes e meia menor, enquanto que na camada mais profunda ocorre diminuição nesta diferença, alcançando uma porcentagem duas vezes e meia menor.

$\mathrm{Na}$ área com eucalipto na camada $0-10 \mathrm{~cm}$ a relação é de $2,73 \%$ de carbono sob a forma de biomassa. Com a profundidade não ocorre variação estatisticamente significativa, com a relação mais elevado encontrada na camada $20-30 \mathrm{~cm}$ com $2,97 \%$ de carbono como biomassa microbiana.

Em comparação à mata, na camada superficial, a relação é cerca de duas vezes menor, nas demais camadas essa diferença praticamente não se altera, alcançando uma porcentagem duas vezes e meia menor na camada $10-20 \mathrm{~cm}$.

As variações encontradas demonstram uma tendência à estabilização nas profundidades maiores, também mostram que em áreas com pastagem, a biomassa microbiana representa um importante compartimento de reserva de nitrogênio, diminuindo a perda deste através dos processos de lixiviação e são mais elevadas que as encontradas por Geraldes(1993).

\subsection{Emissão Gases}

Foram quantificadas as emissões do $\mathrm{CO}_{2}$ (Gás Carbônico) e $\mathrm{CH}_{4}$ (Metano), cujos valores estão apresentados na tabela 7 , bem como as temperaturas nos horários de coleta. Será analisada a emissão desses gases por cultura nos diferentes horários de coleta e também será feita a comparação entre as culturas.

\subsubsection{Emissão de $\mathrm{CO}_{2}$}

$\mathrm{Na}$ área com mata nativa, a média diária de emissão é de $139,5 \mathrm{mgC} \cdot \mathrm{m}^{2} \cdot \mathrm{h}^{-1}$, e o horário de maior emissão é o das 12 horas.

A área com pastagem apresenta maior emissão de $\mathrm{CO}_{2}$. A média diária é de $323,30 \mathrm{mgC} \cdot \mathrm{m}^{2} \cdot \mathrm{h}^{-1}$, e ocorre um aumento ao longo do período, com emissão máxima ocorrendo no horário das 18 horas.

Em relação à mata nativa, a emissão de $\mathrm{CO}_{2}$, é pelo menos duas vezes maior, contrastando com a biomassa microbiana que na área com mata foi maior. Isso demonstra 
que a biomassa na área com pastagem está mais ativa, já que a porcentagem de carbono sob a forma de biomassa microbiana nessa área é quase o dobro em relação a área com mata nativa.

Tabela 7. Emissão dos gases $\mathrm{CO}_{2}$ e $\mathrm{CH}_{4}$ do solo sob mata nativa e culturas.

\begin{tabular}{|c|c|c|c|}
\hline Tratamentos & Temperatura & Média Fluxo de $\mathrm{CO}_{2}$ & Média Fluxo de $\mathrm{CH}_{4}$ \\
\hline & média & $\begin{array}{c}\left(\mathrm{mgC} \cdot \mathrm{m}^{2} \cdot \mathrm{h}^{-1}\right)+\mathrm{dp} \text { por coleta } \\
\text { Mata nativa }\end{array}$ & $\left(\mathrm{mgC} \cdot \mathrm{m}^{2} \cdot \mathrm{h}^{-1}\right)+\mathrm{dp}$ por coleta \\
\hline 7 horas & $15^{0} \mathrm{C}$ & $116,07(66,08)$ & $-0,05(0,03)$ \\
\hline 12 horas & $22^{0} \mathrm{C}$ & $181,16(81,76)$ & $-0,05(0,01)$ \\
\hline 18 horas & $22^{0} \mathrm{C}$ & $135,24(7,70)$ & $-0,05(0,01)$ \\
\hline \multirow[t]{2}{*}{ Média + dp por dia } & $19,6^{0} \mathrm{C}$ & $139,53(54,39)$ & $-0,05(0,02)$ \\
\hline & & Cana-de-açúcar & \\
\hline 7 horas & $19,5^{\circ} \mathrm{C}$ & $87,63(23,49)$ & $0,00(0,05)$ \\
\hline 12 horas & $27,8^{0} \mathrm{C}$ & $117,70(60,17)$ & $0,02(0,02)$ \\
\hline 18 horas & $20,5^{0} \mathrm{C}$ & $125,45(54,62)$ & $0,00(0,02)$ \\
\hline \multirow[t]{2}{*}{ Média $+\mathrm{dp}$ por dia } & $22,6^{0} \mathrm{C}$ & $109,33(31,84)$ & $0,01(0,03)$ \\
\hline & & Pastagem & \\
\hline 7 horas & $14,5^{\circ} \mathrm{C}$ & $264,09(61,74)$ & $0,01(0,03)$ \\
\hline 12 horas & $29,5^{0} \mathrm{C}$ & $349,34(76,86)$ & $0,01(0,01)$ \\
\hline 18 horas & $24,5^{0} \mathrm{C}$ & $356,46(57,57)$ & $0,09(0,06)$ \\
\hline \multirow[t]{2}{*}{ Média + dp por dia } & $22,8^{0} \mathrm{C}$ & $323,30(72,39)$ & $0,04(0,05)$ \\
\hline & & Eucalipto & \\
\hline 7 horas & $15^{0} \mathrm{C}$ & $39,72(14,82)$ & $-0,01(0,01)$ \\
\hline 12horas & $33^{0} \mathrm{C}$ & $49,67(23,52)$ & $-0,03(0,01)$ \\
\hline 18horas & $29^{0} \mathrm{C}$ & $51,07(12,42)$ & $-0,03(0,02)$ \\
\hline Média $+\mathrm{dp}$ por dia & $25,6^{0} \mathrm{C}$ & $46,82(16,14)$ & $-0,02(0,02)$ \\
\hline
\end{tabular}

$\mathrm{Na}$ área com cana-de-açúcar, a média diária é de $109,33 \mathrm{mgC} \cdot \mathrm{m}^{2} \cdot \mathrm{h}^{-1}$, ao longo do período ocorre aumento da emissão de $\mathrm{CO}_{2}$ com a maior no horário das 18 horas, sem, contudo, apresentar grande diferença do horário das 12 horas.

A diferença da emissão de $\mathrm{CO}_{2}$, não é tão evidente quanto à diferença na biomassa microbiana carbono nestas áreas. Este fato deve estar ligado às diferentes proporções de carbono sob a forma de biomassa, que no caso da área com cana-deaçúcar, é pelo menos quatro vezes maior quando comparada à mata nativa, indicando que a biomassa na área com cana-de-açúcar, pode estar mais ativa que na área com mata. 
$\mathrm{Na}$ área com eucalipto, acompanhando a tendência mostrada para a biomassa microbiana, é a que apresenta a menor emissão de $\mathrm{CO}_{2}$, com uma média diária de 46,82 $\mathrm{mgC} \cdot \mathrm{m}^{2} \cdot \mathrm{h}^{-1}$. Como nas demais áreas cultivadas, a emissão aumenta ao longo do período, atingindo seu ponto máximo no período das 18 horas, não apresentando, também, diferença significativa em relação ao horário das 12 horas.

De acordo com os valores apresentados na tabela 7, pode-se notar que a área que apresenta maior emissão de $\mathrm{CO}_{2}$, ao final do período de coleta, é a área com pastagem sendo seguida pela área como mata nativa, cana-de-açúcar e eucalipto. Pode-se notar, ainda, que o fluxo de gases não foi influenciado pela temperatura, apresentando maior emissão de gases no final do dia, exceção feita a área com mata nativa, onde a emissão foi maior no horário das 12 horas.

\subsubsection{Emissão de $\mathrm{CH}_{4}$}

Não é possível analisar com maior precisão a emissão de $\mathrm{CH}_{4}$, pois a quantidade de gás evoluído é muito pequena, permitindo apenas sinalisar uma tendência nas áreas com mata nativa e eucalipto de absorver esse gás, principalmente na primeira. Nas áreas com cana-de-açúcar e pastagem a tendência é inversa, caracterizando a liberação de $\mathrm{CH}_{4}$ para a atmosfera, principalmente na área com pastagem.

\subsection{Fracionamento Químico}

Com a substituição da vegetação nativa por outras cultura, as frações húmicas sofrem alterações quanto à sua distribuição no solo. Na figura 14 pode-se verificar a distribuição dessas frações no solo sob diferentes tipos de cobertura.

$\mathrm{Na}$ área com mata, há predominância do ácido húmico sobre os demais compostos do solo, principalmente na camada mais superficial, seguido pelas frações ácido fúlvico livre, humina e ácido fúlvico. Com a profundidade, há aumento da concentração de ácido fúlvico livre, principalmente na camada $10-20 \mathrm{~cm}$, enquanto que nas demais frações ocorre diminuição.

Com a introdução da pastagem, a proporção relativa entre as frações húmicas se altera. Observa-se o predomínio da humina, em detrimento do ácido húmico, com 
redução considerável do ácido fúlvico, podendo-se supor que o destino do carbono incorporado no solo pela pastagem está sendo preferencialmente na fração humina. O que pode explicar esse comportamenta das frações húmicas é o conteúdo de cálcio no solo, que na área com pastagem é superior ao da mata. A adição de cálcio provoca aumento do conteúdo de complexos húmicos mais estáveis, pois possibilita a formação de Ca-humatos (Oades, 1988).

No solo sob cana-de-açúcar, as frações ácido húmico e humina se equivalem com uma proporção menor de ácido fúlvico. Neste caso, a ação do cálcio não é tão significativa quanto na pastagem, sendo fator importante a porcentagem de carbono remanescente da mata, que influencia o comportamento das frações húmicas.

$\mathrm{Na}$ área com eucalipto, há predominância do ácido húmico, seguido pela humina e ácido fúlvico, seguindo a mesma tendência da mata, com diminuição do ácido fúlvico e aumento da fração ácido fúlvico livre, com a profundidade.
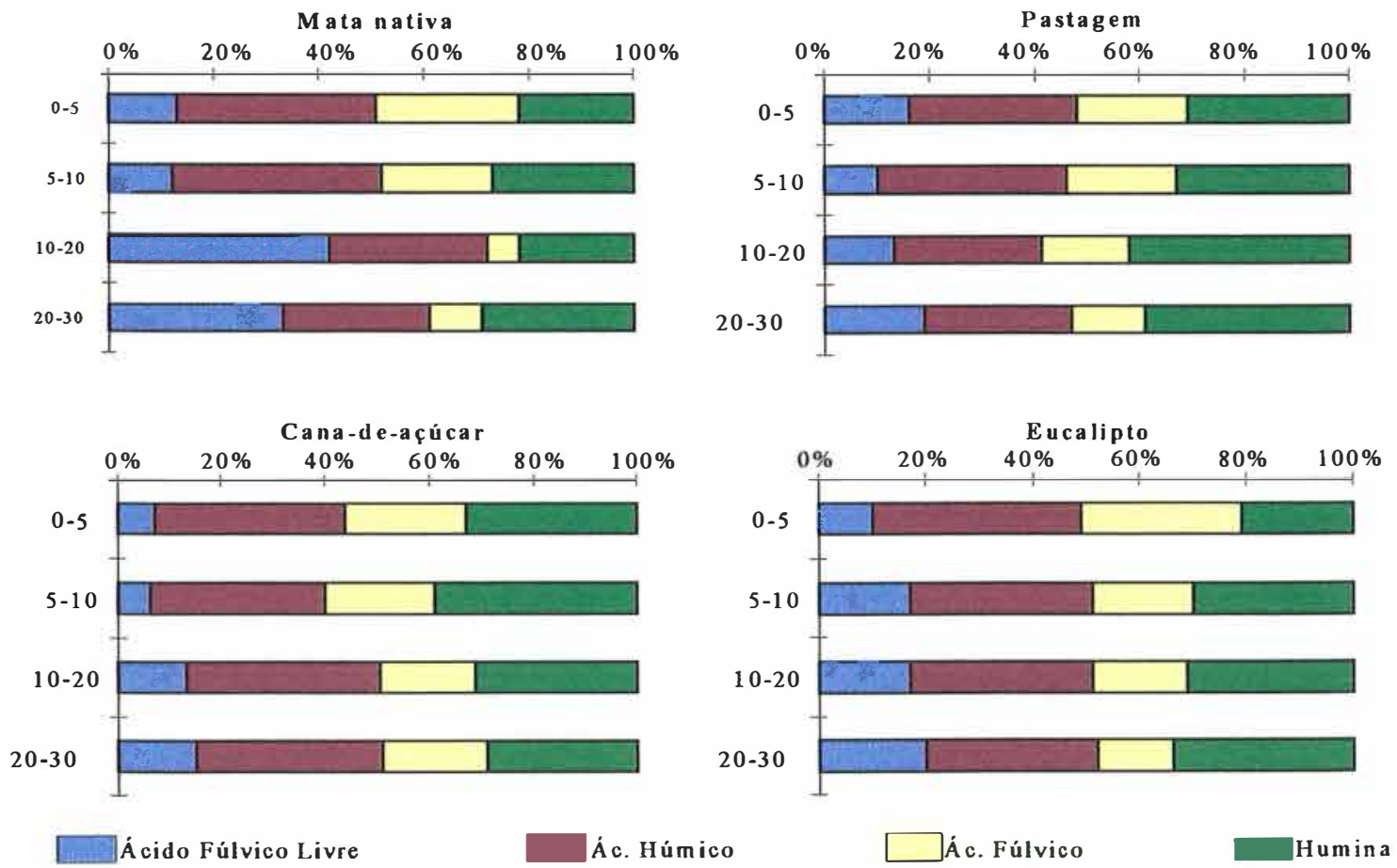

Figura 15 - Distribuição relativa das substâncias húmicas das quatro situações analisadas 


\subsection{Fracionamento Físico}

Com a substituição da vegetação nativa por outras culturas, a distribuição do carbono nas frações granulométricas sofre alterações quanto à sua distribuição no solo. $\mathrm{Na}$ figura 15 pode-se verificar estas alterações.

$\mathrm{Na}$ área com mata, há predominância do carbono na fração F 0-50. Contudo, na camada $0-5 \mathrm{~cm}$, apresenta maior porcentagem de carbono na fração F200-2000, diferindo na distribuição entre a parte orgânica e mineral, com a profundidade esta proporção reduz sensivelmente. A porcentagem de carbono na fração F50-200, se mantém constante nas camadas estudadas.

Com a introdução da pastagem, há predominância do carbono na fração F 0-50. Contudo, a proporção na fração F50-200 aumenta, alcançando na camada $10-20 \mathrm{~cm}$ proporção próxima a apresentada na fração F 0-50. A porcentagem de carbono na fração F200-2000, é a menor em relação as demais áreas

No solo sob cana-de-açúcar, há predominância do carbono na fração F 0-50 e a proporção na fração F50-200 se mantém relativamente constante nas camadas analisadas. A fração F200-2000 apresenta distribuição inconstante, o que deve estar ligado ao manejo do solo.

$\mathrm{Na}$ área com eucalipto, na camada mais superficial, as proporções nas frações 0-50 e 50-200 se equivalem, com a profundidade, ocorre aumento na proporção de carbono na fração F 0-50 e diminuição na fração 50-200. A porcentagem de carbono na fração F200-2000, diminui com a profundidade, exceção feita à camada 10-20 cm, onde esta fração quase se equivale à fração F 0-50, apresentando principalmente o carbono na forma organo-mineral. 

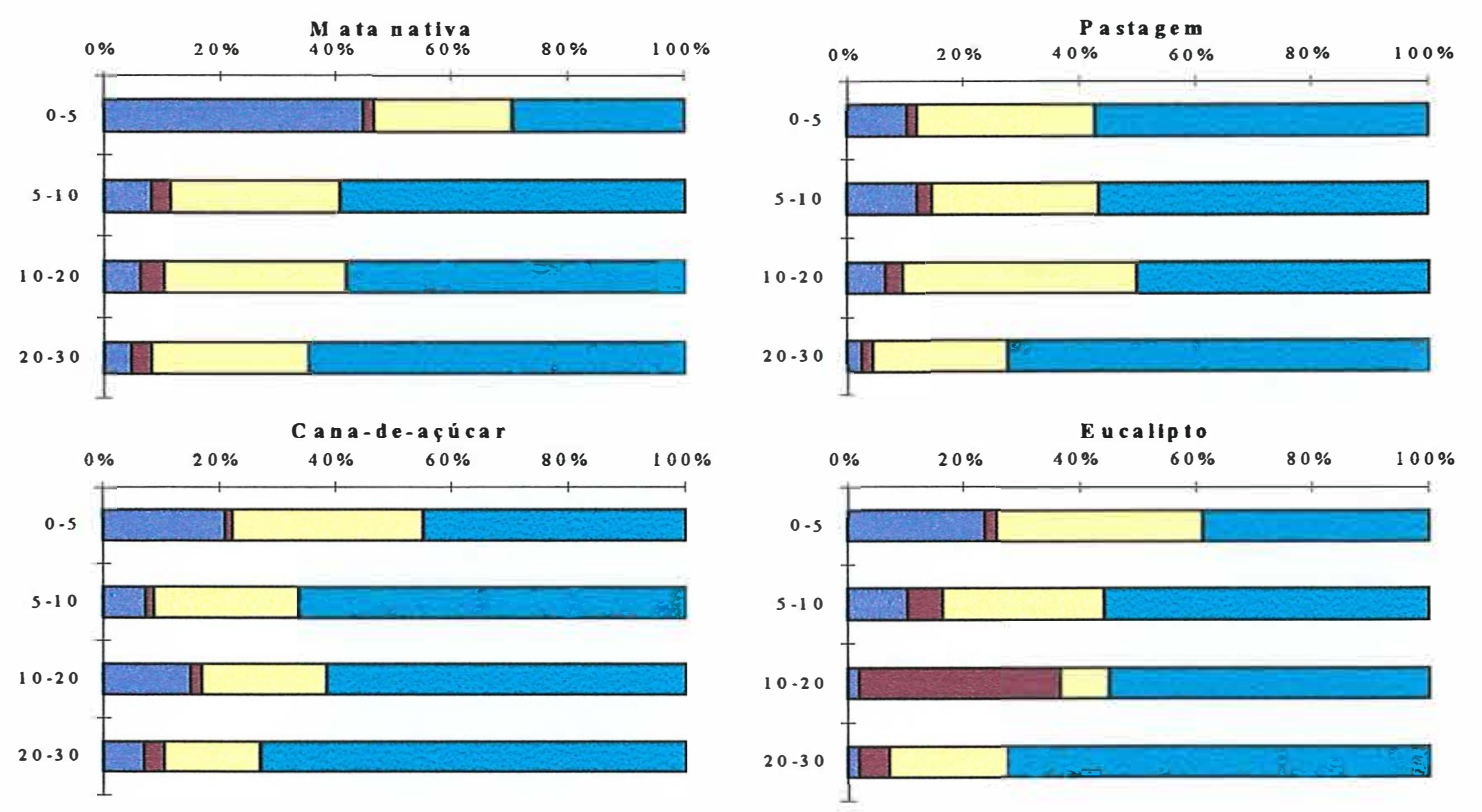

$0-50$

$50-200$

200-2000 Fr. Organo-mineral

$200 \cdot 2000$ Fraçāo Orgânica

Figura 16 - Distribuição relativa do carbono nas frações granulométricas

\subsection{Consequências da alteração do uso da terra}

A partir dos resultados encontrados nas análises de áreas com cultivo do solo com pastagem, cana-de-açúcar e eucalipto, tendo uma mata nativa como referência, podese chegar às considerações apresentadas a seguir.

O conteúdo de matéria orgânica do solo, expresso em toneladas de carbono por hectare, é menor com a introdução de culturas. $\mathrm{Na}$ área com mata nativa o estoque de carbono é de 109,6 $\mathrm{t} \mathrm{ha}^{-1}$. Na área com pastagem o carbono estocado $\left(39,4 \mathrm{t} \mathrm{ha}^{-1}\right)$ equivale a menos da metade, e um quarto deste ainda é remanescente da mata. $\mathrm{Na}$ área com cana-de-açúcar, o conteúdo de carbono é ainda menor $\left(33,4 \mathrm{t} \mathrm{ha}^{-1}\right)$, chegando a apenas trinta porcento do estoque existente na mata natural. Deste estoque, cerca de setenta por cento é ainda remanescente do sistema natural. Com a introdução do eucalipto, começa a ocorrer uma recuperação deste estoque, alcançando ao final do período de vinte anos $59,61 \mathrm{t} \mathrm{ha}^{-1}$, o equivalente à metade daquele encontrado para a mata nativa. 
Com relação ao nitrogênio, foi observado que na área com cana-de-açúcar o conteúdo $\left(1,2 \mathrm{t} \mathrm{ha}^{-1}\right)$ é bem menor em relação as demais áreas, diminuindo para menos da metade do estoque encontrado na área de mata nativa $\left(2,8 \mathrm{t} \mathrm{ha}^{-1}\right)$. Nas áreas com pastagem e eucalipto os estoques se equivalem $\left(1,7 \mathrm{tha}^{-1}\right.$ e $1,6 \mathrm{t} \mathrm{ha}^{-1}$ respectivamente), e representam cerca de sessenta porcento em relação à mata.

$\mathrm{O}$ pH do solo sofreu alterações significativas com a introdução das culturas, exceção feita a área com eucalipto. Houve aumento nas áreas com pastagem, atingindo 5,4 e principalmente cana-de-açúcar que alcançou 6,1.

A composição granulométrica não sofreu diferença significativa com a introdução das culturas. Entretanto, foi observado aumento da densidade do solo. Na área com mata, a densidade variou entre 0,93 e 1,26. $\mathrm{Na}$ área com eucalipto a densidade foi semelhante àquela da mata nativa, com valores entre 1,02 e 1,28. O aumento da densidade foi verificado no solo sob pastagem, o qual variou entre 1,19 a 1,39 , e principalmente na área com cana-de-açúcar, com densidades entre $1,19 \mathrm{e} 1,47 \mathrm{~g} \mathrm{~cm}^{-3}$.

Houve diminuição na estabilidade dos agregados nas áreas com pastagem e cana-de-açúcar, principalmente nesta última, a qual passa por manejo anual que torna o solo mais sujeito a ação dos fatores do ambiente. Com a substituição de parte da área com pastagem por eucalipto, ocorre uma recuperação da estabilidade dos agregados. Nas áreas com mata e eucalipto a agregação ocorre principalmente a maior quantidade de matéria orgânica no solo, enquanto que nas áreas com pastagem e cana-de-açúcar a agregação está também relacionada à maior presença de cátions trocáveis no solo.

A biomassa microbiana está concentrada na camada mais superficial, onde a disponibilidade de matéria orgânica é maior. Os maiores valores de biomassa microbiana carbono foram encontrados na área com mata nativa $\left(382,36 \mu \mathrm{g} \mathrm{C}^{-1}\right)$. A área que mais se aproximou das condições encontradas para a mata foi a pastagem $\left(213,15 \mu \mathrm{g} \mathrm{C} \mathrm{g}^{-1}\right)$, seguida da área com cana-de-açúcar $\left(151,12 \mu \mathrm{g} \mathrm{C} \mathrm{g}^{-1}\right)$ e eucalipto $\left(96,57 \mu \mathrm{g} \mathrm{C} \mathrm{g}^{-1}\right)$, sendo que na área com eucalipto a biomassa $\mathrm{C}$ foi muito menor que nas demais áreas. Com relação a biomassa $\mathrm{N}$, a maior concentração também ocorreu nos dez centímetros iniciais do solo. A área sob mata apresentou a maior estimativa $\left(67,67 \mu \mathrm{g} \mathrm{N} \mathrm{g}^{-1}\right)$, a pastagem foi a que mais se aproximou do sistema nativo com $24,44 \mu \mathrm{g} \mathrm{N} \mathrm{g}^{-1}$, e na área 
com eucalipto a biomassa é de $16,38 \mu \mathrm{g} \mathrm{N} \mathrm{g}^{-1}$. Os menores valores foram registrados para a área com cana-de-açúcar, com apenas $4,96 \mu \mathrm{g} \mathrm{N} \mathrm{g}^{-1}$.

Os valores de carbono imobilizado sob a forma de biomassa microbiana em relação ao carbono total do solo variaram com a substituição da mata nativa. As áreas que apresentaram a maior relação, foram as com cana-de-açúcar, variando entre 2,4 e 4,0\%, e pastagem entre 2,0 e 4,5\%. A área com mata apresentou relações variando entre 0,9 a $2,5 \%$, e as menores relações são encontradas no solo sob eucalipto, variando entre 0,4 e 0,5\%. Com o aumento da profundidade, a relação aumenta, exceção feita a área com eucalipto. O nitrogênio imobilizado como biomassa microbiana, em relação ao nitrogênio total do solo, foi maior na área sob mata, com valores entre 5,6 e 6,8\%. Em seguida, estão a pastagem com 4,7 e 5,3\%, eucalipto com valores entre 2,6e 3,0\%. As menores relações são encontradas na área com cana-de-açúcar, com valores entre 1,6 e 2,7\%. Estas relações demonstram que a biomassa microbiana $\mathrm{N}$, representa um importante compartimento de reserva de nitrogênio orgânico.

A emissão de $\mathrm{CO}_{2}$ foi maior na área com pastagem, com média diária de 323,3 $\mathrm{mgC} \cdot \mathrm{m}^{2} \cdot \mathrm{h}^{-1}$, seguida pela área com mata nativa com $139,5 \mathrm{mgC} \cdot \mathrm{m}^{2} \cdot \mathrm{h}^{-1}$, cana-de-açúcar $109,3 \mathrm{mgC} \cdot \mathrm{m}^{2} \cdot \mathrm{h}^{-1}$ e eucalipto $46,8 \mathrm{mgC} \cdot \mathrm{m}^{2} \cdot \mathrm{h}^{-1}$, evidenciando a maior atividade da biomassa no solo sob pastagem e o estoque de carbono sob a forma de biomassa. Já a emissão de $\mathrm{CH}_{4}$, indicam apenas a tendência para a absorção nas áreas com mata nativa e eucalipto e liberação nas áreas com pastagem e cana-de-açúcar.

Com a substituição da vegetação nativa por culturas ( plantas $\mathrm{C}_{4}$ ), ocorre um aumento na constituição isotópica do solo, que é mais evidenciada nas camadas mais superficiais não sendo tão marcante nas camadas mais profundas. $\mathrm{O} \delta^{13} \mathrm{C}$ passa de $-29,1 \%$ na área com mata para -16,1\% na área com pastagem e -19,2\%o para a cana-de-açúcar. Isto é devido a maior deposição de material da nova cultura para a decomposição. Com a entrada do eucalipto, o sistema fotossintético volta a ser $\mathrm{C}_{3}$ e novamente ocorre a diminuição da constituição isotópica do solo $-25,1 \%$, voltando a valores próximos aos da mata nativa.

A substituição da cobertura vegetal, provoca uma alteração na fonte de carbono para o solo, que começa a contribuir juntamente com o remanescente do sistema natural 
para o estoque no solo. A área com cana-de-açúcar é a que apresenta a maior porcentagem de carbono remanescente da vegetação nativa, ou seja cerca de sessenta por cento. $\mathrm{Na}$ área com pastagem o remanescente da mata nativa é menor, cerca de vinte por cento e se faz mais evidenciado nas camadas mais profundas. 


\section{CONCLUSÕES}

A substituição da vegetação nativa por culturas altera as propriedades de uma areia quartzosa álica do Município de São Pedro-SP.

Com a substituição da vegetação nativa por pastagem, ocorre aumento na

densidade do solo, diminuição da estabilidade dos agregados, e da acidez, principalmente nas camadas mais superficiais. Os teores de matéria orgânica do solo e biomassa microbiana ( $\mathrm{C}$ e $\mathrm{N}$ ) diminuem, porém, o estoque de carbono sob a forma de biomassa microbiana aumenta. $\mathrm{O}$ estoque de nitrogênio sob a forma de biomassa mantém relação próxima a apresentada para a área com mata nativa. Aumenta a liberação de $\mathrm{CO}_{2}$ para a atmosfera.

Quando parte da área ocupada com pastagem é substituída com cana-de-açúcar, a densidade do solo e o $\mathrm{pH}$ aumentam, a estrutura dos agregados na camada arável tornase menor. Os teores de matéria orgânica do solo e biomassa diminuem ainda mais. Os estoques de carbono sob a forma de biomassa microbiana mantém uma relação próxima daquela encontrada para a pastagem, enquanto que o estoque de nitrogênio sob a forma de biomassa diminui. A liberação de $\mathrm{CO}_{2}$ do solo é menor em relação a mata nativa.

Convertendo-se parte da área com pastagem em área com eucaliptos, a densidade do solo, o pH, o grau de agregação e os teores de MOS voltam a assumir valores próximos aos da mata. Entretanto, a biomassa microbiana é menor , provavelmente devido ao poder alelopático dos esxudados radiculares, bem como os estoques de carbono e nitrogênio sob a forma de biomassa. A emissão de $\mathrm{CO}_{2}$ é muito pequena. 


\section{LITERATURA CITADA}

ALLISON, F.E. Soil aggregation - Some facts and fallacies as seen by a microbiologist. Soil Science, Baltimore, v.2, n. 106,p.136-143,1968.

ANDERSON, J.M. \& INGRAM, J.S.I. Tropical Soil Biology and Fertility: A Handbook of Methods, Wallingford-UK. C A B International 1989. 171p.

ANDREUX, F.; CERRI, C.C.; VOSE, P.B. ; VITORELO, V.A. Potential of isotope. Methods for determining imput and turnover in soils. In: HARRISON, A.; INENSON, P. \& HEAL, O.W. (eds.). Nutrient Cycling in Terrestrial Ecossystem:

Field Methods Application and Interpretation. Essex: Elsevier Science Publish., 1990. p.259-275.

ANGULO, R.J.; ROLOFF, G.; SOUZA, M.L.P.. Correlação entre diferentes formas de determinação e representação de estabilidade e resistência de agregados do solo. Revista Brasileira de Ciência do Solo, v.8, p.7-12, 1984.

ANDREUX, F.; CERRI, C.C.; VOSE, P.B. ; VITORELO, V.A. Potential of isotope. Methods for determining imput and turnover in soils. In: HARRISON, A.; INENSON, P. \& HEAL, O.W. (eds.). Nutrient Cycling in Terrestrial Ecossystem: Field Methods Application and Interpretation. Essex: Elsevier Science Publish., 1990. p.259-275.

BAVER, L.D., GARDNER, W.H., J GARDNER, W.R. Soil Physics, New York - USA. 1972. $498 \mathrm{p}$.

BONDE,T.A.; SCHNÜRER, J.; ROSSWALL, T. Microbial biomass a fraction of potentially mineralizable nitrogen in soils from long-term field experiments. Soil Biology and Biochemistry, v.20, p.447-452, 1988. 
BROOKES, P.C.; LANDMAN, A.; PRUDEN, G. JENKINSON, D.S.. Chloroform fumigation and the release of soil nitrogen. Soil Biology Biochemistry v.17, p.837842, 1985.

CAMARGO, O. A. de; MONIZ, A.C.; JORGE, J.A.; VALADARES, J.M.A.S. Métodós de análise química, mineralógica e física de solos do Instituto Agronômico, Campinas, 1986. 94p. (IAC. Boletim Técnico, 106).

CERRI, C. C.; VOLKOFF, B.; EDUARDO, B.P.. Efeito do desmatamento sobre a biomassa microbiana em Latossolo amarelo da Amazônia. Revista Brasileira de Ciência do Solo, v.9, n. 1, p.1-4, 1985.

CERRI, C.C.. Dinâmica da matéria orgânica do solo no agrossistema cana-de-açúcar. Piracicaba, 1986, 197p.. Tese (Livre-Docência) - Escola Superior de Agricultura “Luiz de Queiroz", Universidade de São Paulo.

CERRI, C. C.. Dinâmica da matéria orgânica em solos de pastagens. In: SIMPÓSIO SOBRE ECOSSISTEMA DE PASTAGENS. Anais 1989. p. 135-147.

CERRI, C. C.; FELLER, C.; CHAUVEL, A. Evolução das principais propriedades de um latossolo vermelho escuro após desmatamento e cultivo por doze e cinquenta anos com cana-de-açúcar. Pedologia. v.26, n. 1 p 37-50. 1991.

CERRI, C. C.; MORAES, J.F.L.. Consequências do uso e manejo do solo no teor de matéria orgânica . IN: ENCONTRO SOBRE MATÉRIA ORGÂNICA DO SOLO _ PROBLEMAS E SOLUCÕES. Anais. Botucatu. 1992. p 25-36.

CHANEY, K. \& SWIFT, R.S. The influence of organic matter on aggregate stability in some British soils. Journal of Soil Science, v.35, p. 223-230, 1984.

CHAUVEL, A. GRIMALDI, M., TESSLER, D. Changes in soil proe-space distribuition following deforestation and revegetation: an example from the Central Amazon Basin. Forest Ecology and Management, v.38, p. 259-271, 1991.

COELHO, R.M. Influência da vinhaça, da fertilização mineral e do cultivo em características químicas da matéria orgânica e da fração mineral de um Latossolo Vermelho-Escuro. Viçosa, 1990. 84p. Dissertação (Mestrado) - Universidade Federal de Viçosa. 
CUNNINGHAM, R.K. The effect of clearing a tropical forest soil.. Journal of Soil Science. v. 14, p 334-345. 1963.

DABIN, B. Etude d'extration de la matérie humique des sols. Science du Sol. v. 1. p.4763.1971

DZUREC, R.S ; BOUTTON, T.W.; CALDWELL, M.M. \& SMITH, B.N. Carbon isotope ratios of soil organic matter and their use in assessing community composition changes in Curley Valley, Utah. Oecologia, v. 66, p. 17-24. 1985.

EMBRAPA. Serviço Nacional de Levantamento e Conservação do Solo. Manual de Métodos de Análise de Solos, Rio de Janeiro, 1979.

FERNANDES, F.A. Matéria Orgânica e características fisico-químicas de podzóis hidromórficos no Pantanal Mato-Grossense: alterações pelo uso com pastagens cultivadas.. Piracicaba. 1993. 75p. Dissertação (Mestrado) - Centro de Energia Nuclear na Agricultura, Universidade de São Paulo.

GARAY, I. ; SILVA, B.A.O.. Humus florestais: Síntese e diagnóstico das interrelações vegetação solo. In: Simpósio "Estrutura, funcionamento e manejo de ecossistemas", . Rio de Janeiro, 1993. Anais. Rio de Janeiro Dep. Ecologia, IB., UFRJ.

GERALDES, A.P.A. Carbono, nitrogênio e biomassa microbiana do solo de uma cronossequência floresta-pastagem em Paragominas, Pará (Amazônia Oriental). Piracicaba., 1993. 68p. Dissertação (mestrado) - Escola Superior de Agricultura "Luiz de Queiroz", Universidade de São Paulo.

JENKINSON, D.S. ; LADD, J.N.. Soil Biochemistry. New York: E.A. Paul and J.N. Ladd, Eds., 1981.p.415-471: Microbial biomass in soil. Measurement and turnover.

JENNY, H. The Soil Resource. New York: 1980.345p.

KEMPER, W.D. Aggregate Stability. IN: Black, C.A., ed. Methods in soil analysis. Madison, Wisconsin, America Society of Agronomy, Part 1, p.511-519. (Agronomy, 9) 1965.

KEMPER, W.D. \& CHEPIL, W.S. Aggregate Stability. IN: Black, C.A., ed. Methods in soil analysis. Madison, Wisconsin, America Society of Agronomy, Part 1, p. 499509.(Agronomy, 9) 1965. 
KIEHL, E. J. Manual de edafologia - relações solo-planta. São Paulo, Agronômico Ceres, 1979. 264p.

LAVELLE, P.; BLANCHART, E.; MARTIN, A.; SPAIN, A.V.; MARTIN, S.. Impact of soil fauna on the properties of soil in the humid tropics. In: Myths and Science of Soils of the Tropics. Soil Science Society of America and American Society of Agronomy. S. Segoe Rd., Madison, USA. Special Publication Nㅜㄹ 29, p.157-185. 1992.

LUIZÃO, F.J. \& SCHUBART, H.O.R.. Litter producion and decomposition in a terra firme forest of Central Amazônia. Experientia, v.43, p.259-265. 1987.

MANN, L.K. Changes in soil carbon storage after cultivation. Soil Science, v.142, n.5, p. 279-288, 1986.

MARTINS, P.F.S.; CERRI, C.C.; VOLKOFF, B. , ANDREUX, F. Consequências do cultivo e do pousio sobre a matéria orgânica do solo sob floresta natural na Amazônia Oriental. Acta Amazonica, v. 20, p.19-28, 1990a.

MARTINS, P.F.S.; CERRI, C.C.; VOLKOFF, B. , ANDREUX, F. Efeito do desmatamento e do cultivo sobre características físicas e químicas do solo sob floresta natural na Amazônia Oriental. Revista do Instituto de Geociências, Universidade de São Paulo. v. 11, n.1, p.21-33, jan-jun. 1990b.

MORAES, J.F.L., Conteúdo de Carbono e Nitrogênio e tipologia de horizontes nos solos da Bacia Amazônica. Piracicaba, 1991.84p.Dissertação (mestrado) - Centro de Energia Nuclear na Agricultura, Universidade de São Paulo.

NEPSTAD, D.C.; UHL, C. ; SERRÃO, E.A.S., Recuperation of a degraded Amazonian landscap: forest recovery and agricultural restoration. AMBIO v.20, n.6, p.248-255. 1991.

OADES, J.M. Soil organic matter and strutural stability mechanisms and implications for management. Plant and Soil, v.76, p. 319-337., 1984.

OLIVEIRA, J.B., PRADO, H. Carta pedológica semidetalhada do Estado de São Paulo.folha de Piracicaba, São Paulo: Secretaria da Agricultura, 1989. Esc. $1: 1000.000$. 
OMETTO, J.C. Registros e Estimativas dos Parâmetros Metereológicos da Região de Piracicaba, SP. Piracicaba: FEALQ/USP, 1989.

PENNING, L.; EDUARDO, B.P.; CERRI, C.C.. Os métodos da fumigação-incubação e fumigação-extração na estimativa da biomassa microbiana de solos da Amazônia. Revista Brasileira de Ciência do Solo, v. 16, p.31-38. 1992.

PICCOLO, M.C.. Comportamento do Nitrogênio do solo em cronossequências de Floresta-Pastagem em Rondônia. Piracicaba. 1994. 69p. Tese (Doutorado) - Centro de Energia Nuclear na Agricultura, Universidade de São Paulo.

POWLSON, D.S.; BROOKES, P.C.; CHRISTENSEN, B.T.. Measurement of soil microbial biomass provides an early indication of changes in total soil organic matter due to straw incorporation. Soil Biology and Biochemistry, v.19, n.2, p.159-164. 1987.

SANCHEZ, P.A., VILACHICA, J.H., BANDY, D.E. Soil fertility dynamics after clearing a tropical rainforest in Peru. Soil Science Society of American Journal. № ${ }^{0}$, p.1171-11178. 1983.

SÃO PAULO. Secretaria do Meio Ambiente. Bacia do Rio Piracicaba: estabelecimento de metas ambientais e reenquadramento dos corpos d'água - São Paulo, 1994. 81 p. (Série Relatórios).

SELBACH, P.A.. Acidez dos solos e atividade microbiana. IN: Seminário Sobre Corretivos da Acidez do Solo, 2., Santa Maria, 1989. Anais. Santa Maria, UFSM, p.62-73. 1989.

SPARLING, G.P. ; ROSS, D.J. Biochemical methods to estimate soil microbial biomass: Current developments and aplications. In: Soil Organic Matter Dynamics and Sustainability of Tropical Agriculture. Munlogov, K. \& Mercks, R. eds. IITA/K.U. p. 21-37. 1993.

STEVENSON, J.F. Humus chemistry, genesis, composition, reaction. New York, John Wiley \& Sons, 1982, 443p.

UZÊDA, M.C.. Efeitos do cultivo e do pousio sobre o solo e a vegetação secundária da Amazônia Oriental. Campinas, 1995. 81p. Dissertação (Mestrado) - Universidade Estadual de Campinas. 
VANCE, E.D.; BROOKES, P.C.; JENKINSON, D.S.. An extraction method for measurement soil microbial biomass-C. Soil Biology and Biochemistry v.19, n. 6 p. 703-707, 1987. 